\title{
GEOTHERMAL PROGRESS MONITOR REPORT NO. 11
}

DECEMBER 1989

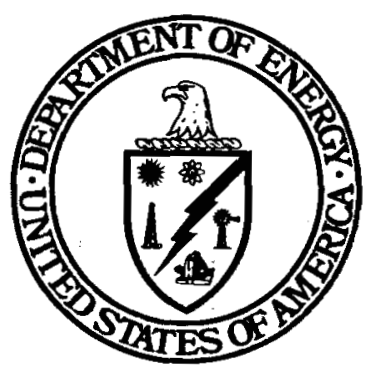

\section{U.S. Department of Energy \\ Assistant Secretary for Conservation and Renewable Energy Geothermal Technology Division \\ Washington, D.C. 20585}

Prepared in Cooperation with the Interagency Geothermal Coordination Council with the Assistance of

Meridian Corporation, Alexandria, Virginia 


\section{DISCLAIMER}

This report was prepared as an account of work sponsored by an agency of the United States Government. Neither the United States Government nor any agency Thereof, nor any of their employees, makes any warranty, express or implied, or assumes any legal liability or responsibility for the accuracy, completeness, or usefulness of any information, apparatus, product, or process disclosed, or represents that its use would not infringe privately owned rights. Reference herein to any specific commercial product, process, or service by trade name, trademark, manufacturer, or otherwise does not necessarily constitute or imply its endorsement, recommendation, or favoring by the United States Government or any agency thereof. The views and opinions of authors expressed herein do not necessarily state or reflect those of the United States Government or any agency thereof. 


\section{DISCLAIMER}

Portions of this document may be illegible in electronic image products. Images are produced from the best available original document. 
Introduction $\ldots \ldots \ldots \ldots \ldots \ldots \ldots \ldots \ldots \ldots$ 1

The Federal Beat . . . . . . . . . . . . . . 3

The Industry Scene . . . . . . . . . . . . . 15

Financing $\ldots \ldots \ldots \ldots \ldots \ldots \ldots \ldots \ldots . \ldots 21$

Development Status $\ldots \ldots \ldots \ldots \ldots \ldots \ldots$

Leasing and Drilling $\ldots \ldots \ldots \ldots \ldots \ldots$

State and Local . . . . . . . . . . . . . . 47

International ................ 53

Technology Transfer . . . . . . . . . . . 61

Directory $\ldots \ldots \ldots \ldots \ldots \ldots \ldots \ldots . \ldots 73$

COVER PHOTO: The first California Energy Co. plant at the Coso, California, geothermal field. Complex will total 230 MWe when completed. 
This issue of the Geothermal Progress Monitor (GPM) is the 11th since the inception of the publication in 1980. It continues to synthesize information on all aspects of geothermal development in this country and abroad to permit identification and quantification of trends in the use of this energy technology.

In addition, the GPM is a mechanism for transferring current information on geothermal technology development to the private sector, and, over time, provides a historical record for those interested in the development pathway of the resource. In sum, the Department of Energy makes the GPM available to the many diverse interests that make up the geothermal community for the multiple uses it may serve.

This issue of the GPM points up very clearly how closely knit many of those diverse interests have become. It might well be called an "international issue" since many of its pages are devoted to news of geothermal development abroad, to the efforts of the U.S. industry to participate in overseas development, to the support given those efforts by federal and state agencies, and to the formation of the International Geothermal Association (IGA). All of these events indicate that the geothermal community has become truly international in character, an occurrence that can only enhance the future of geothermal energy as a major source of energy supply worldwide.

A more subtle difference in this issue may also be noted by readers of previous issues. Heretofore, the content of most articles placed them clearly within the subject area of one particular section -- the FEDERAL BEAT or INDUSTRY SCENE, for example. Now, however, the cooperation and coordination of activities among the various segments of the geothermal community is such that a number of articles discuss activities that relate to two or more sections. For example, the editor elected to place a story entitled "Geothermal Industry Looking to Foreign Markets" in the INDUSTRY SCENE. However, the reader will find that it would have been almost equally at home in the FEDERAL BEAT or INTERNATIONAL sections. Similarly, resource problems at The Geysers are discussed under DEVELOPMENT STATUS, but it will be noted that industry, the federal government, and state and local agencies are participating in research projects designed to solve the problems.
Another change in this issue is that the hot water geothermal power plant table in DEVELOPMENT STATUS has been rearranged according to Known Geothermal Resource Areas (KGRA). Previously, the plants were listed in chronological order of their construction, but in that format, the pattern of development was difficult to discern. With the new arrangement, trends according to area can easily be identified.

An item of considerable interest to the geothermal community is described in the FEDERAL BEAT -- i.e., the new method employed by DOE's Geothermal Technology Division for setting its research and development objectives. All objectives, it is reported, are now focused on the reductions in the cost of geothermal power that can be achieved with any given technology considered for R\&D effort. This approach is made possible by a new cost-of-power model which permits an analysis of cost impacts from each element of hydrothermal R\&D. It is expected that this approach will help industry expand the economically viable geothermal resource base. It is noted that similar models are in preparation for geopressured and hot dry rock resources.

The FEDERAL BEAT also reports on current $R \& D$ activities, the results of which will be transferred to industry for near-term or future application. This section also describes new federal legislation designed to promote geothermal and other renewable energy sales abroad and discusses an important Environmental Protection Agency decision on geothermal wastes.

Throughout the GPM, sources are identified when a news item or report is excerpted directly from another publication. When no source is given, the information was derived from Department of Energy activities, from individuals involved in the event reported, or was developed by the GPM staff for inclusion in this issue.

GPM readers are invited to submit comments on this publication and news of developments that could be reported in issue No. 12. Your communications will be most welcome. 
TOTAL RESOURCE BASE

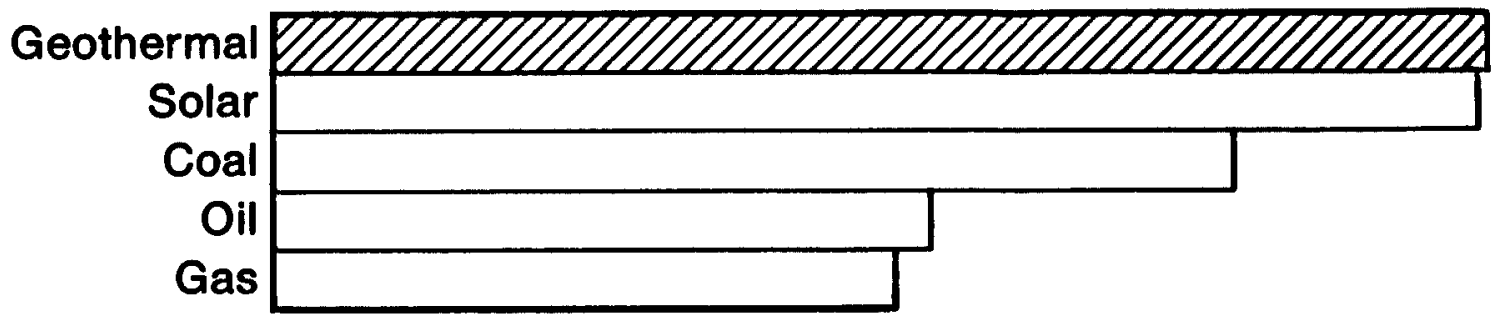

ACCESSIBLE RESOURCES
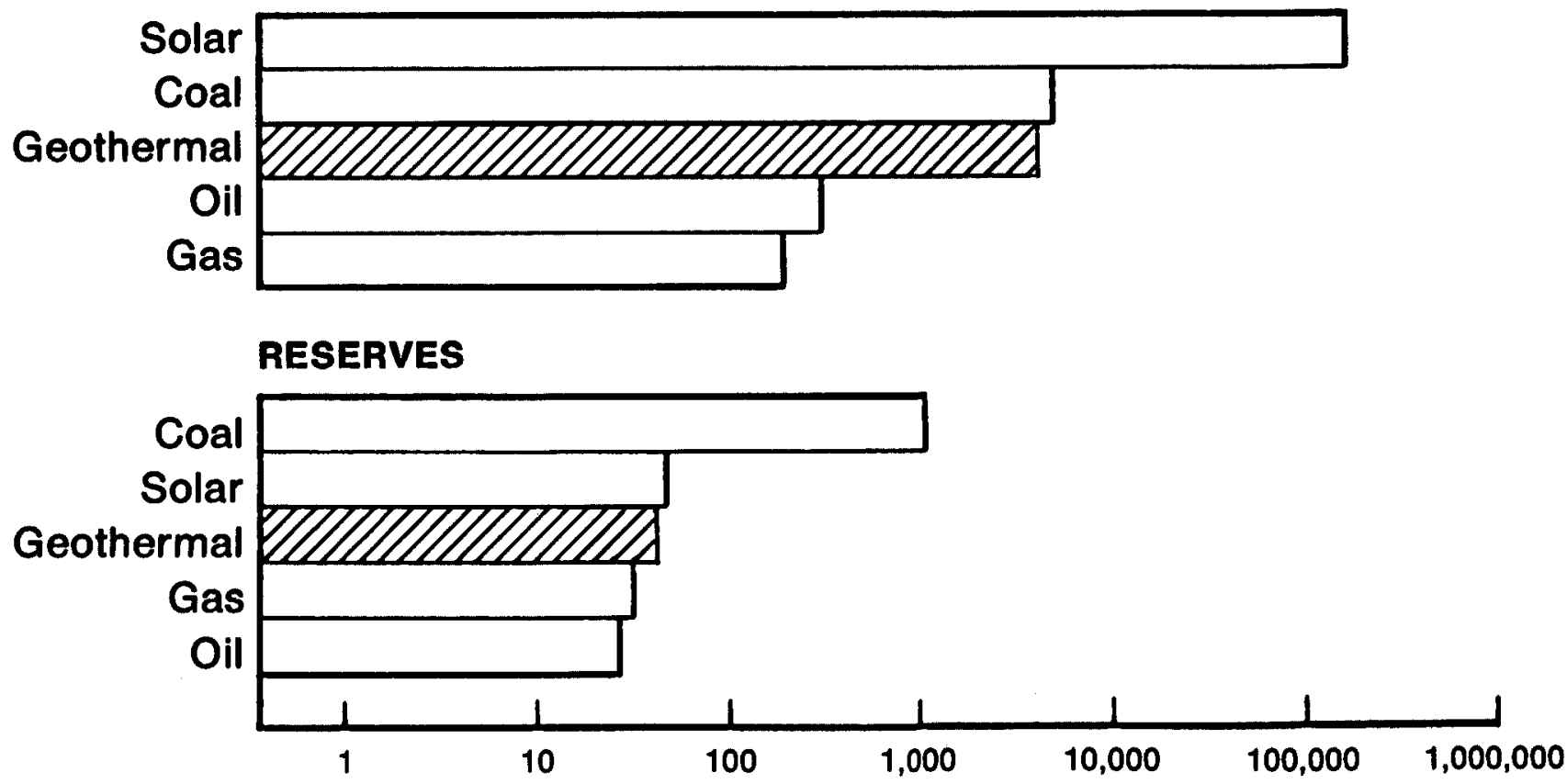

BILLION BARRELS OF OIL EQUIVALENT

NEW DOE U.S RESOURCES COMPARISON

(See article on Page 3 for definitions.) 


\section{PRESIDENT ANNOUNCES DEVELOPMENT OF NATIONAL ENERGY STRATEGY; INDUSTRY SEES IMPORTANT IMPLICATIONS FOR GEOTHERMAL ENERGY}

Citing the need for "a clear energy blueprint to take the U.S. into the next century," President Bush has directed Secretary of Energy James D. Watkins to lead the development of a National Energy Strategy (NES). Watkins described the strategy to the Senate Committee on Energy and Natural Resources on July 26, 1989, as "an action plan essential to providing this Nation, in the years to come, with adequate supplies of competitively priced, clean energy. This strategy will...contain specific short-term, mid-term, and long-term recommendations. [It] will chart our course, set our pace, and provide mileposts by which to evaluate our progress in providing the energy our economy needs, while protecting the nation's health, safety, and environment."

Expressing strong support for the goals of the strategy, David N. Anderson, executive director of the Geothermal Resources Council, said, "Geothermal energy provides a ready response to the criteria set by the Secretary." "This resource," he continued, "is the largest energy base with which this country is endowed. It is competitively priced in many areas, and it is clean, safe, and environmentally benign. Geothermal power is a here-and-now baseload reality, the industry is geared to meet near-term challenges, and cooperative industry/government research and development are underway to prepare for broad price competition in the 1990s and beyond. Direct uses of geothermal energy provide all the same benefits on a smaller scale, and collectively displace millions of barrels of oil per year at current usage."

In addressing major considerations in development of the strategy, the Secretary emphasized as a "central issue" the predominant role of the production and use of energy in global climate change concerns. "It is entirely proper," he said, "that the Department of Energy assume a leading role...in defining the initiatives that can be undertaken - publicly and privately -- in response to this threat.".
Anderson again pointed to the proven performance of geothermal energy as a readily available means to reduce this country's contribution of carbon dioxide $\left(\mathrm{CO}_{2}\right)$ to the greenhouse effect. "Geothermal's carbon dioxide emissions are negligible. Depending on the technology used and the geochemistry of the geothermal fluid, geothermal power plants generally contribute only about 3 percent of the $\mathrm{CO}_{2}$ per unit of energy of that contributed by the combustion of coal and 8 percent of natural gas emissions. Closed geothermal binary systems have no gaseous emissions, and, in the newest flash steam technology, all noncondensible gases are injected to the subsurface."

In response to the Secretary's concern on means to evaluate and share technological responses to global warming with developing countries, Anderson pointed to the International Geothermal Association as a mechanism already in place. Geothermal energy, he noted, is available in many parts of the developing world -- Central and South America, Africa, and Asia -and over 50 countries either already use geothermal energy or are in some stage of evaluating or developing the resource. This availability also provides a response to the determination by the recent Paris Economic Summit of world leaders that energy technologies are needed in developing countries to protect the global environment.

Anderson pledged the support of the GRC and the IGA in implementing the Energy Strategy as it unfolds. section.)

(See related story in the INTERNATIONAL

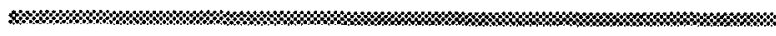 GEOTHERMAL ENERGY CONFIRMED AS COUNTRY'S LARGEST ENERGY RESOURCE}

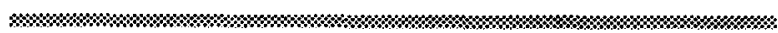

A recent study (Characterization of U.S. Energy Resources and Reserves) by DOE's Office of Renewable Energy confirmed that geothermal energy is by far the most abundant energy source in the U.S., accounting for nearly $\mathbf{4 0}$ percent of the total resource base, as shown below. The total resource base is defined as: 
"A concentration of naturally occurring solid, liquid, or gaseous materials in or on the Earth's crust in such form that economic extraction of a commodity is currently or potentially feasible."

Geothermal energy received this high ranking on the basis of much more conservative estimates than those published by the U.S. Geological Survey in Circulars 726, 790, and 892 . Instead, DOE's study used the 1979 recalculation of the USGS figures by the National Academy of Sciences. The recalculation excludes the fraction of geothermal resources that cannot be currently exploited by any known technology, and those for which economic extraction is not considered feasible in the foreseeable future. Thus, the total geothermal resource base in the DOE study includes reservoirs with a minimum temperature of $80^{\circ} \mathrm{C}\left(176^{\circ} \mathrm{F}\right)$ at a maximum depth of 6 kilometers, except for geopressured resources which are included to $7 \mathrm{kms}$. Low-temperature resources in the $40^{\circ}-80^{\circ} \mathrm{C}\left(104^{\circ} \mathrm{F}-176^{\circ} \mathrm{F}\right)$ range to a depth of $3.2 \mathrm{kms}$ and the methane in the sandstone layers of geopressured formations are also included. The USGS estimates included reservoirs with a minimum temperature of $15^{\circ} \mathrm{C}$ $\left(59^{\circ} \mathrm{F}\right)$ to a depth of $10 \mathrm{kms}$.

Based on the conservative NAS estimates, the geothermal portion of the accessible resource base is only 3.4 percent. This is the subset of the total resource base that can be located, mined, or extracted by technology currently available or that which will be available in the very near future ( 3 to 5 years) without regard to economic feasibility. Since costs were not considered in establishing the accessible resource base, all four categories of geothermal energy -- hydrothermal, geopressured, hot dry rock, and magma - were included.

However, the reserve estimate, which is based on USGS data, is limited to hydrothermal convection systems within $3 \mathrm{kms}$ of the surface with temperatures of $150^{\circ} \mathrm{C}\left(300^{\circ} \mathrm{F}\right)$ and above -the highest quality hydrothermal fluids -- and accounts for 3.9 percent of the total reserves. The more difficult hydrothermal fluids, geopressured brines, hot dry rock, and magma failed the economic test to qualify as "reserves" - i.e., they cannot be produced economically today at $\$ 18-\$ 20 /$ barrel oil prices nor can they produce electricity today for sale at prices competitive with $\$ 18-\$ 20 /$ barrel oil. Technological advances are expected to increase geothermal's reserve share over the next decade.

\section{"RESEARCH AND DEVELOPMENT FOR THE GEOTHERMAL MARKETPLACE": THEME OF DOE GEOTHERMALPROGRAM REVIEW VII}

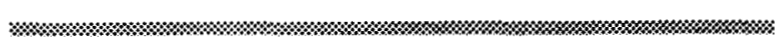

Addressing the theme "Research and Development for the Geothermal Marketplace," the geothermal community gathered in San Francisco, on March 21-23, 1989, for the DOE Geothermal Program Review VII. The emphasis of the technology presentations was the close link between the research objectives of DOE's Geothermal Technology Division (GTD) and potentially competitive market applications. The GTD objectives themselves were the focus of Program Review VI in April of 1988.

In his PR VII opening remarks, Dr. John E. Mock, GTD Director, discussed the technology successes of the past, the products of more recent research, and new DOE emphases on looking to technologies of the future. In addressing historic milestones, Mock said, "I find it encouraging that in working together, significant progress has been made in advancing technology and reducing costs. The progress is especially significant when government and industry combine their resources to conduct research that neither party could afford alone."

He described as "very gratifying" the technology payoffs that can be observed from earlier program efforts. For example, he pointed to increases in drilling efficiency of about 30 percent from 1981-1985; increases in temperature tolerance of cements from $200^{\circ} \mathrm{C}$ in 1978 to $500^{\circ} \mathrm{C}$ today with an increase to $600^{\circ} \mathrm{C}$ projected by 1992; and the development of elastomers that will resist temperatures up to $300^{\circ} \mathrm{C}$. Noting that many in the PR VII audience have participated, Mock congratulated the geothermal community on these achievements.

Turning to more recent technology accomplishments, Mock enumerated noteworthy Fiscal Year 1988 successes as follows: 
- Excellent agreement between theory and laboratory data in testing a laboratory model of drill string dynamics and successful completion of the prototype high-temperature televiewer (a government/ industry project).

- Scale inhibitor applications in geopressured wells that continued to permit high-volume production.

- A drilling rate at the Fenton Hill, New Mexico, hot dry rock experimental site two and one-half times faster than the rate achieved in 1978-79, indicating a 60 percent reduction in well cost.

The four new technologies Mock described as "exciting" for industry application in the near future include acoustical telemetry for measuring while drilling, radar fracture mapping, deep seismic surveys, and a new understanding of borehole breakouts. He requested that industry keep DOE closely informed on the utility and performance of these technologies as they are put to use in the marketplace.

A topic of heightened interest for geothermal technology, Mock noted, is its major advantage over fossil fuels in reducing atmospheric levels of carbon dioxide, a major contributor to global warming. Actual data from specific geothermal power plants show that their $\mathrm{CO}_{2}$ emissions are only a small fraction of those of coal-fired plants, geothermal's largest competitor. Mock noted that this issue may foster more rapid acceptance of geothermal power by utilities.

He also identified two techniques that may be "long shots," but which might prove to be useful and less costly for geothermal exploration - multispectral remote sensing for geothermal signatures and biogeochemical prospecting. The former would give wide geographic coverage with an inexpensive tool to identify "blind" resources which are thought to exist in an area, but where there are no distinctive surface manifestations. The latter is a new technique worth preliminary investigation to determine whether trace chemistry - e.g., arsenic, boron -- in plants can reveal a geothermal presence.

These techniques are only the newest in DOE's geothermal R\&D portfolio designed to achieve its overall objective of reducing the cost of geothermal power. This objective is supported by specific, time-marked, quantitative targets for technology development.

Describing the objectives at PR VI in April 1988, Mock said, "They constitute an umbrella strategy under which we are all working to significantly improve the technology that will help the geothermal industry reduce the costs of geothermal power and thus expand the economically viable resource base." He emphasized that the objectives will drive all research projects over the next five to seven years.

The impact of objective achievement was highlighted in Mock's concluding remarks to the PR VII audience: "If the government/industry research effort can shave the cost of geothermal power to a fraction-of-a-cent below everyone else's cost of power...customers in the marketplace will be waiting for geothermal service."

While the DOE geothermal program is reviewed on a number of levels each year, Program Reviews $\mathrm{VI}$ and VII are the latest in a series of reviews in which all elements of the geothermal community are invited to participate. Copies of the printed proceedings (Conferences 880477 and 890352 , respectively) may be obtained from:
National Technical Information Service
U.S. Department of Commerce
Springfield, Virginia 22161

\section{GTD OBJECTIVES RECOGNIZED AT THREE LEVELS}

Three levels of objectives govern the content of GTD's program. Level I objectives provide a target for decreasing the total cost of power for generating electricity from geothermal energy. Level II objectives address incremental improvements in the cost and/or performance of major system components that make up a geothermal power project. And Level III objectives identify improvements in cost, efficiency, and certainty of performance to which individual research activities are geared. A 
Geothermal Energy Project Cost Tree shows how the three levels relate to one another.

The achievement of research objectives (Level III) ultimately influences the total cost of power
- Hydrothermal - Reduce the life-cycle cost of producing electricity from liquiddominated, hydrothermal resources to 3 to 7 cents per kilowatt-hour (kWh) by 1997. This compares with a cost range

\section{GEOTHERMAL PROJECT COST TREE}

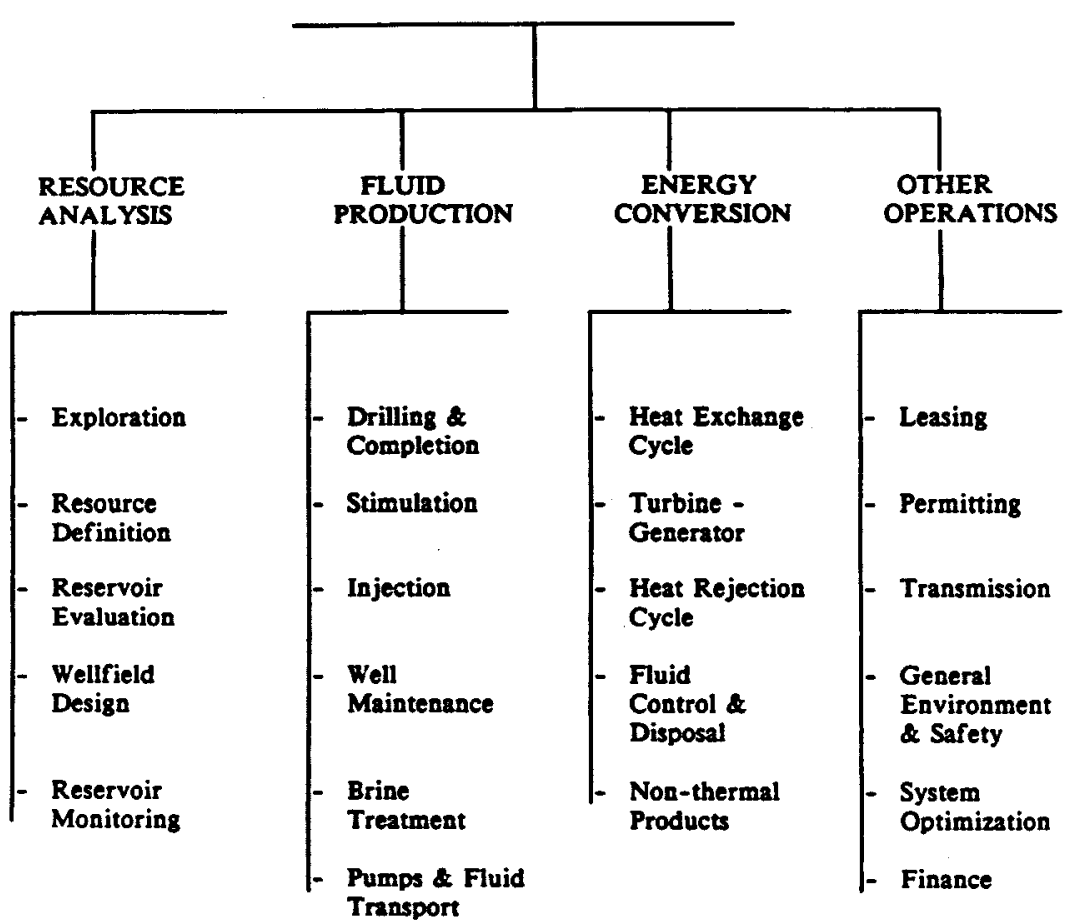

(Level I). The magnitude of this effect is estimated with a cost-of-power model which translates improvements in technology brought about by research into reductions in the cost of power. The model, entitled "Impacts of Geothermal Research," or IMGEO, is based on actual operating experience from geothermal power plants and uses reference data from eight site-plant configurations.

For the present, the cost-of-power model applies solely to the use of hydrothermal resources. Models for other resource types (i.e., geopressured and hot dry rock) have not yet evolved. However, the project cost tree offers a simple, consistent means of expressing objectives for these resources. At present, the Level I objectives for each resource type are: of 4 to 15 cents/kWh for hydrothermal electric energy as of 1986. The equivalent weighted average reduction is $30-40$ percent.

- Geopressured-Geothermal - Improve the technology to the point where energy could be produced commercially from the geopressured resource at a cost equivalent to 6 to 10 cents $/ \mathrm{kWh}$ by 1997.

- Hot Dry Rock - Provide the technology to enable industrial hot dry rock projects to generate power at 5 to 8 cents/kWh by 1997 . 
Magma - Create the technology by which energy could be produced experimentally from magma energy at an equivalent cost of 10 to 20 cents/kWh by 2000 .

The cost-of-power numbers are normalized to the base year of 1986. For the hydrothermal case, the range in the numbers is due to cost differences among the various site-plant combinations in the model. The ranges for the other resources represent the product of different economic analyses and prognoses by experts on likely changes in technology. The year specified for achieving the objective reflects the target for completing all subordinate research objectives (Level III) and not necessarily the year in which cost savings will be realized by industry. Reductions in the cost of power should accrue incrementally as industry adopts the new technology and gains operating experience.

The GTD research objectives are not fixed; it is expected that they will change in response to available funding or as additional knowledge and experience are gained. Some lines of research may have to be abandoned if they prove unsuccessful. Others may take their place if they have potential for ultimately reducing the cost of power.

\section{FIRST POWER GENERATION WITH GEOPRESSURED BRINES UNDERWAY IN TEXAS}

In a joint DOE/Electric Power Research Institute R\&D effort, a hybrid power system is generating electricity with geopressured brines at the Pleasant Bayou well in Brazoria County, Texas. The hybrid system is utilizing both the heat of the brines and their methane content. The methane is separated from the fluid portion at the wellhead and used to fuel two gas engines. Exhaust heat from the engines is used with the brine to vaporize isobutane in a binary power cycle.

Use of both forms of energy is estimated to improve conversion efficiency by 15 to 20 percent over the same amount of fuel and geothermal fluid processed separately. Operation of the combined system will provide an opportunity to evaluate the enhanced performance of combined cycles and to demonstrate fuel flexibility in an individual plant. This approach would allow a resource developer to reduce costs and risks by optimizing production for various economic climates and would improve the mix in a utility's generating system. (See Page 8.)

The experimental system is designed for 10,000 barrels-per-day brine flow, with estimated power production of $980 \mathrm{~kW}$ (net). Current plans call for a 9-month test, ending about May 1, 1990. Depending on system performance, the test period may be extended.

The plant operations and tests are managed by The Ben Holt Co. engineers while the well management and overall project responsibility remain with the Idaho National Engineering Laboratory.

\section{HDR WELL SUCCESSFULLY REPAIRED; YEAR-LONG FLOW TEST OF FENTON HILL HDR RESERVOIR TARGETED TO BEGIN IN 1990}

After successfully completing the redrilling of a damaged well at the Fenton Hill, New Mexico, experimental hot dry rock facility, the Los Alamos National Laboratory (LANL), manager of the project, is concentrating on a long-term flow test of the man-made reservoir. The test is designed to provide industry with assurance that such a reservoir can be operated for many years without major problems or a significant decrease in the rate and quality of energy production. While industrial advisors to the DOE HDR project feel that a longer testing period would be desirable, it has been concluded that a successful and welldocumented one-year flow test of this hightemperature system should convince industry that HDR geothermal energy merits investment in commercial development. Testing is tentatively scheduled to begin in September 1990.

LANL conducted similar tests in 1979-80 of a smaller, shallower HDR reservoir designed to prove the concept. The tests produced pressurized hot water at temperatures and flow rates suitable for many commercial uses such as space heating and food processing. If located in an urban area, the system could have heated 


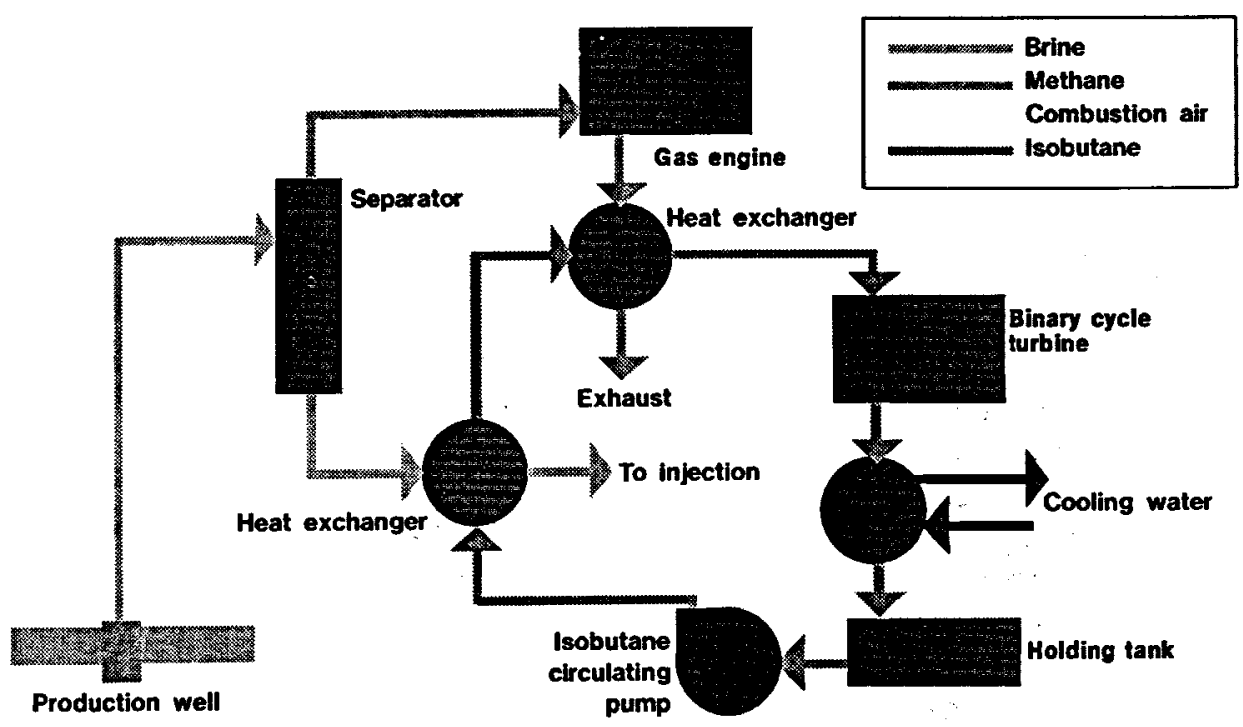

DEDICATION OF HYBRID GEOPRESSURED PLANT

(September 15, 1989)

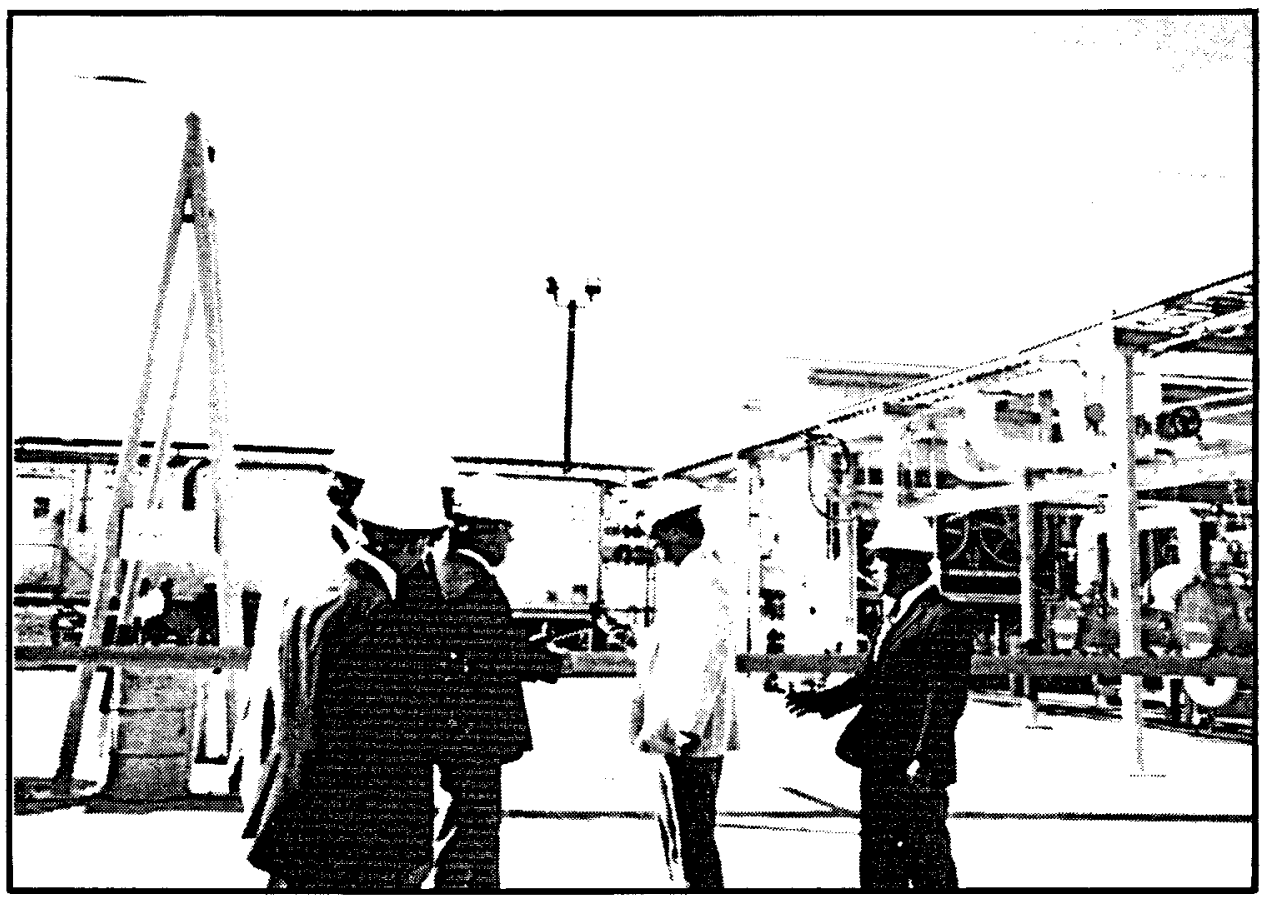


several hundred homes. A small binary power generation unit was also operated successfully for a brief period, but the reservoir was not hot enough for commercial power generation.

To approach commercial energy requirements, a larger, deeper, hotter Phase II reservoir was designed and constructed at Fenton Hill. This system has been operated successfully in a previous 30-day test, and is now being readied for the long-term effort.

Damage occurred in the well used to create the Phase II reservoir and to serve as the injection well during the long-term test. LANL officials note that the well design was based on the rather benign Phase I experience, which did not include a realistic worst case prediction of well conditions. However, the redrilling of the well required only $\mathbf{3 0}$ days to drill 2,600 feet of additional hole, which at 87 feet per day is an excellent rate in hard rock. This is nearly 2.5 times faster than that achieved during the original drilling a few years ago. Due to new technology, if the wells were drilled today, they would cost 60 percent less than their original cost. Not only does the cost savings brighten the future of HDR and other geothermal programs, LANL managers point out that the advances will also benefit the oil and gas industry and the Continental Scientific Drilling Program. The 60 percent savings in drilling costs correspond to a 30 percent reduction in the overall costs of power production.

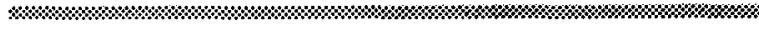 \\ STUDY SUGGESTS THAT HOT DRY ROCK POWER GENERATION AT ROOSEVELT HOT SPRINGS, UTAH, COULD COMPETE WITH NEW COAL PLANTS}

While many uncertainties remain, the results of a geotechnical evaluation indicate that a 50 MWe hot dry rock (HDR) facility at Roosevelt Hot Springs, Utah, could generate power at a cost competitive with new coal-fired plants using Utah coal. This study, called a Hot Dry Rock Venture Risks Investigation, is the first site-specific

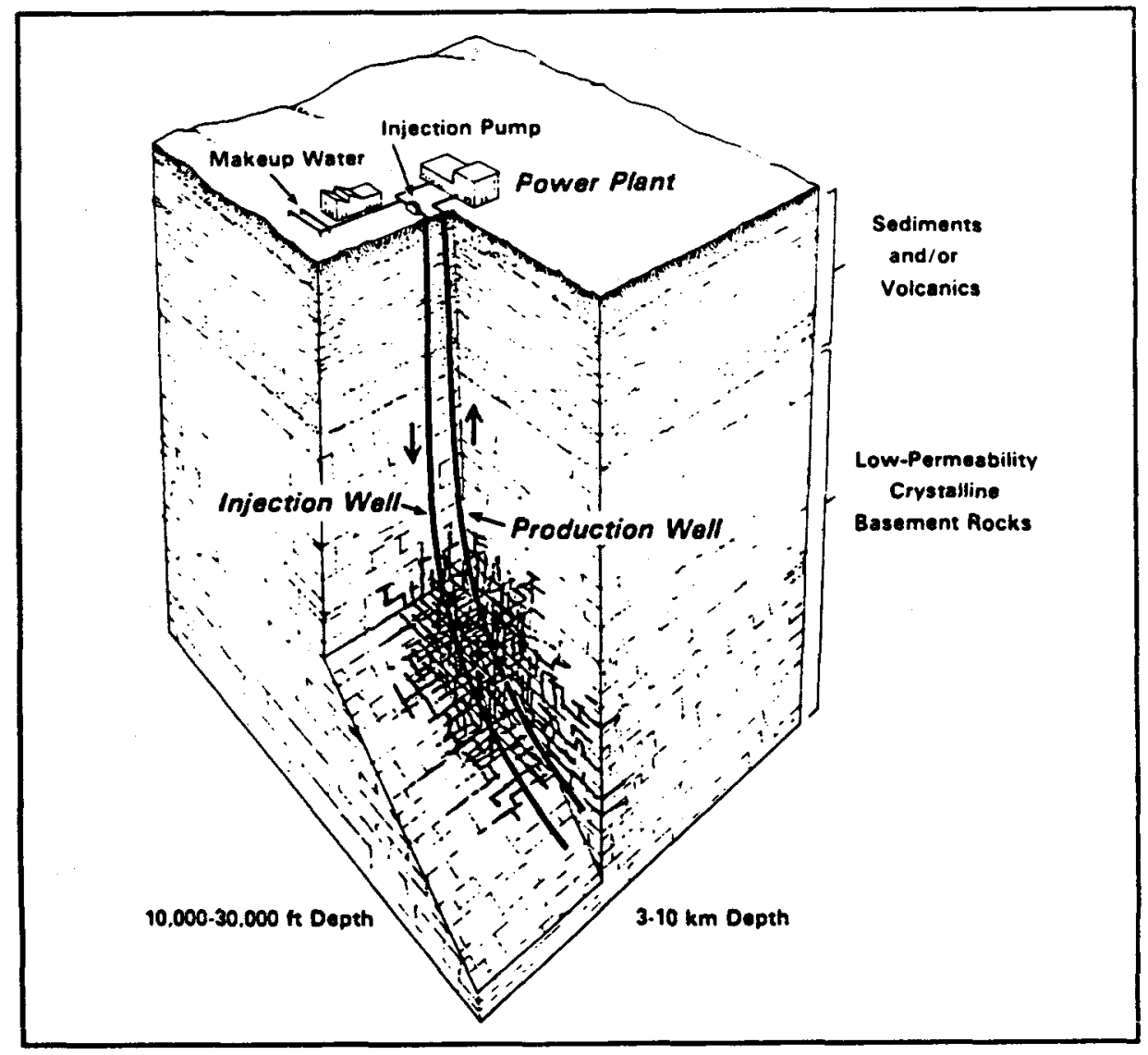

HOT DRY ROCK (HDR) GEOTHERMAL SYSTEM

CONCEPT FOR LOW-PERMEABILITY FORMATIONS 
evaluation to test the commercial readiness of HDR technology.

All HDR installations to date are research and development facilities. The largest, at Fenton Hill in New Mexico and Rosemanowes, England, have proved the technology concept by drilling into hot dry rock, hydraulically fracturing the rock mass, and extracting thermal energy by circulating water through man-made fractures.

The Roosevelt Hot Springs investigation found that the area appears to be well suited to extending the experimental concept to commercial power production. A large, hot granitic rock mass exists at technically feasible drilling depths, and water to operate the facility could be produced from the shallow aquifer underlying the site. The study report notes, however, that adequate information on the rock properties in the deep subsurface HDR target zone is not currently available. Drilling to the target depth is needed to furnish data to resolve these technical uncertainties.

Similarly, information now available leaves considerable uncertainty about expected reservoir performance. Even though a concept for creating the reservoir was developed that would use present-day equipment and techniques, the technology has not been demonstrated in an HDR application.

The study recommended a site-specific industrial HDR experiment at Roosevelt Hot Springs to resolve these issues and to obtain sitespecific data needed for design and evaluation. If the experiment confirms the technical and economic projections of the geotechnical evaluation, a commercial-size, first-of-a-kind power plant may be possible.

\section{FEDERAL EPA LEAVES REGULATION OF MANY GEOTHERMAL WASTES TO STATES}

A congressionally mandated study of the wastes generated by the exploration, development, and production of geothermal energy by the Environmental Protection Agency resulted in a very favorable determination by the Agency. It concluded that regulating these wastes under the hazardous waste management provisions of the Resource Conservation and Recovery Act (RCRA) (P.L. 94-580) is "unwarranted because of the relatively low risk of the wastes and the presence of generally effective state and federal regulatory programs." (Federal Register, June 6, 1988). While EPA indicated its intent to fill "gaps" in its regulation of oil and gas wastes, also covered by the study, the Agency stated in its required Report to Congress that it "sees no need for additional (geothermal) regulations...."

EPA further noted that Subtitle C of RCRA, the section that requires comprehensive "cradle to grave" management of hazardous wastes, "offers little flexibility to take into account the varying geological, climatological, geographic, and other differences characteristic of oll and gas drilling and production sites...." While this specific statement does not include geothermal per se, indications throughout the Federal Register and Report to Congress discussions are that EPA used the similarities between the industries and the lack of specific geothermal data to extend many oil and gas findings to geothermal.

For example, it was recognized that the quantity and quality of geothermal data did not permit quantitative risk modeling of the industry. Thus, because of the similarities in waste types and management practices between the industries, quantitative oil and gas risk results were used for a qualitative analysis of the potential risks of geothermal facilities.

In another facet of its study, EPA found no significant cases of damages associated with the exploration, development, and production of geothermal energy. This finding led to its conclusion that existing regulatory programs are probably effective even though some of the wastes do exhibit hazardous characteristics primarily toxicity, due to the presence of trace metals, and corrosivity.

The wastes exempt from Subtitle C jurisdiction and, thus, from subsequent amendments to the subtitle include:

- drilling media and cuttings

- $\quad$ fluids from geothermal reservoirs

- $\quad$ piping scale and flash tank solids

- $\quad$ precipitated solids from brine effluent 
- $\quad$ settling pond wastes

- $\quad$ hydrogen sulfide wastes

- $\quad$ cooling tower drift

- cooling tower blowdown.

These wastes are also exempt from the provisions of the Hazardous and Solid Waste Amendments of 1984 (HSWA) (P.L. 98-616) which amends Subtitle C. Nonexempt wastes -- those that remain subject to Subtitle $\mathrm{C}$ and amendments -- include:

- wastes originating in the electric generator

- waste lubricants

- $\quad$ waste hydraulic fluids

- $\quad$ waste solvents

- waste paints

- $\quad$ sanitary wastes.

The EPA study was mandated by a 1980 amendment to RCRA which temporarily exempted some categories of large volume wastes pending further study. The EPA Report to Congress of December 1987 is entitled Management of Wastes from the Exploration, Development, and Production of Crude Oil, Natural Gas, and Geothermal Energy.

Currently, the states typically require that the above federally exempt wastes be handled as hazardous wastes if chemical analysis indicates hazardous characteristics. In California, for example, prior to the disposal of any material, it must be analyzed using prescribed procedures, and the results compared to codified threshold limiting concentrations. If any parameter equals or exceeds the limitation, disposal at a site approved for such wastes is mandated.

Use of such sites is costly and their capacity and availability are becoming increasingly limited as applicable standards become more stringent and expensive. Thus, some possibility exists that the states may consider, if they are not doing so already, following the lead of the Hazardous and Solid Waste Amendments cited above. This statute finds that land disposal, which by definition includes injection, is the least favorable method of managing hazardous waste. In effect, it prohibits the disposal of hazardous wastes, mandating pretreatment to "substantially diminish the toxicity of the waste or substantially reduce the likelihood of migration of hazardous constituents from the waste so that short-term and long-term threats to human health and the environment are minimized." Pretreatments that would permit compliance with this type of state regulation are under development, as described below.

\section{DOE COOPERATING WITH GEOTHERMAL INDUSTRY TO DEVELOP BIOLOGICAL SOLUTIONS TO WASTE MANAGEMENT}

In recognition that low-cost processes for the removal of toxic metals from geothermal residues would be needed before major development could occur in some otherwise economically attractive areas -- e.g., the Salton Sea - DOE began to research waste treatment methods soon after the Hazardous and Solid Waste Amendments to RCRA became effective in 1984.

Microorganisms are being identified and tested that interact with toxic metals to convert them to soluble species for subsequent injection back into the reservoir or concentrate them for removal by conventional processes. Samples of geothermal brine residues containing elevated concentrations of heavy metals have been treated with cultures of several strains of acidophilic bacteria--Thiobacillus thiooxidans and Thiobacillus ferrooxidans -- with promising results. In order to determine the commercial, technical, and economic feasibility of this process, experiments are being scaled up to larger volumes, and the relative merits of column vs. bed-type reactors will be evaluated. Industry is participating in these studies by contributing proprietary wastes. 
GEOTHERMAL DRILLING ORGANIZATION CITED BY NATIONAL ACADEMY OF SCIENCES AS MODEL FOR GOVERNMENT/INDUSTRY COOPERATION; ACADEMY SUPPORTS CONTINUED FEDERAL GEOTHERMAL R\&D

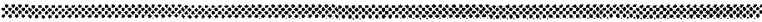

After a study of the numerous cooperative mechanisms potentially available to DOE's Geothermal Technology Division for cost-shared R\&D, the National Academy of Sciences concluded that the Geothermal Drilling Organization "stood out above all other mechanisms for government-industry cooperation for near-term resource development." The study, contracted by DOE, was conducted by a blueribbon committee of geothermal experts and nongeothermal members from industry, academia, and government which also concluded that the government should continue its role in geothermal R\&D "because the young industry could not be expected to carry it on alone." "Because of current economic conditions and the state of development in the geothermal industry," the committee said, "it is unrealistic to expect that private industry can or will fund most of the R\&D needed in this area. The short- to mid-term profit potential is not sufficiently high, and the industry is not mature enough to generate the profits needed to support significant R\&D."

The Geothermal Drilling Organization was formed in 1985 to foster technology aimed at reducing the cost of drilling and maintaining geothermal wells. Its approach to this task is to establish nonprofit cooperative funding arrangements among industry members of GDO and DOE for specific projects of near-term value to the industry. The emphasis is on products or services that can be commercialized when the project is completed. Each project is jointly funded by $D O E$ and participating industry partners with industry providing at least 50 percent of the total cost.

The Academy described the GDO as "an apparently successful operation that responds to most issues raised (by the Committee)....and generally meets the criteria for success."

\section{GDO PROJECT SELECTION AND FUNDING}

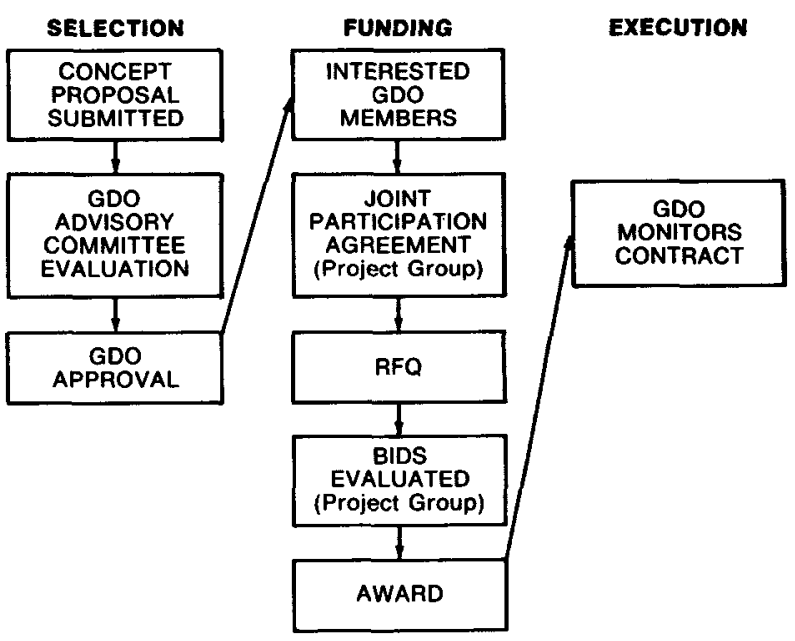

NEW LEGISLATION SUPPORTS MORE
AGGRESSIVE FEDERAL RENEWABLE
ENERGY R\&D; GEOTHERMAL
FUNDING AUTHORIZATIONS WOULD
BE INCREASED

\%ం\%

Legislation (S.488) was signed by the President on December 11, 1989, that directs the Secretary of Energy to pursue an aggressive program of research, development, and demonstration of renewable energy technologies, including joint ventures with the private sector. Using the authority of the Nonnuclear Energy R\&D Act of 1974, the Secretary is directed to:

- $\quad$ achieve, as soon as practicable, cost competitive use of renewable energy technologies without need of federal financial incentives.

- establish long-term federal research goals and multiyear funding levels; and

- foster collaborative R\&D efforts with the private sector through government support of a vigorous program of innovative projects.

Funding for geothermal R\&D would be authorized up to $\$ 19$ million for $F Y 1991, \$ 20.5$ million for FY 1992, and \$23 million for FY 1993. 
These figures compare to $\$ 39-\$ 40$ million for photovoltaics over the three years and $\$ 4-\$ 5$ million for ocean energy systems, the high and low authorizations among the renewable technologies.

The legislation, entitled the "Renewable Energy and Energy Efficiency Technology Competitiveness Act of 1989," directs that recommendations for geothermal cost goals and other pertinent geothermal goals be set forth in a mandated report one year after enactment of the Act.
In addition to addressing renewable energy technology R\&D, the legislation would also require that the Committee on Renewable Energy, Commerce, and Trade (CORECT) establish, in consultation with affected industries, a plan to increase U.S. renewable energy technology exports, including geothermal energy products and services. A budget to continue CORECT activities through FY 1993 is included. (See "Geothermal Industry Looking to Foreign Markets" in INDUSTRY SCENE.) 
EFFECTS OF PURPA CONTRACTS ON INSTALLED CAPACITY OF U.S. GEOTHERMAL POWER PLANTS

CAPACITY, MWe Net

ANNUAL INCREMENT

CUMULATIVE

\begin{tabular}{|c|c|c|c|c|c|c|}
\hline YEAR & $\begin{array}{l}\text { NON- } \\
\text { PURPA }\end{array}$ & PURPA & TOTAL & $\begin{array}{l}\text { NON- } \\
\text { PURPA }\end{array}$ & PURPA & TOTAL \\
\hline $\begin{array}{l}1960 \\
1963 \\
1967 \\
1968 \\
1971 \\
1972 \\
1973 \\
1975 \\
1979 \\
1980 \\
1981 \\
1982 \\
1983 \\
1984 \\
1985 \\
1986 \\
1987 \\
1988 \\
1989\end{array}$ & $\begin{array}{r}11 \\
13 \\
27 \\
27 \\
106 \\
106 \\
106 \\
106 \\
165 \\
242 \\
3 \\
123 \\
295 \\
80 \\
371 \\
110 \\
0 \\
166 \\
30\end{array}$ & $\begin{array}{r}0 \\
0 \\
0 \\
0 \\
0 \\
0 \\
0 \\
0 \\
0 \\
23 \\
0 \\
0 \\
2 \\
32 \\
51 \\
24 \\
36 \\
199 \\
245\end{array}$ & $\begin{array}{r}11 \\
13 \\
27 \\
27 \\
106 \\
106 \\
106 \\
106 \\
165 \\
265 \\
3 \\
123 \\
297 \\
112 \\
422 \\
134 \\
36 \\
365 \\
275\end{array}$ & $\begin{array}{r}11 \\
24 \\
51 \\
78 \\
184 \\
290 \\
396 \\
502 \\
667 \\
909 \\
912 \\
1035 \\
1330 \\
1410 \\
1781 \\
1891 \\
1891 \\
2057 \\
2087\end{array}$ & $\begin{array}{r}0 \\
0 \\
0 \\
0 \\
0 \\
0 \\
0 \\
0 \\
0 \\
23 \\
23 \\
23 \\
25 \\
57 \\
108 \\
132 \\
168 \\
367 \\
612\end{array}$ & $\begin{array}{r}11 \\
24 \\
51 \\
78 \\
184 \\
290 \\
396 \\
502 \\
667 \\
932 \\
935 \\
1058 \\
1355 \\
1467 \\
1889 \\
2023 \\
2059 \\
2424 \\
2699\end{array}$ \\
\hline $\begin{array}{l}1990 \\
1991\end{array}$ & $\begin{array}{l}0 \\
0\end{array}$ & $\begin{array}{l}60 \\
20\end{array}$ & $\begin{array}{l}60 \\
20\end{array}$ & $\begin{array}{l}2087 \\
2087\end{array}$ & $\begin{array}{l}672 \\
692\end{array}$ & $\begin{array}{l}2759 \\
2779\end{array}$ \\
\hline
\end{tabular}

SOURCE: MERIDIAN CORPORATION

Enactment of the Public Utilities Regulatory Policies Act of 1978 (PURPA) provided critical support to the development and growth of the geothermal industry. To quote one industry leader, "Without PURPA, there would be no 'hot water' geothermal industry." The major benefits to the industry include:

- unregulated status

- guaranteed access to power markets

- avoided cost payments

- long-term contracts

- guaranteed access to existing transmission facilities. 


\section{CONFERENCE CHRONICLES INDUSTRY'S MOVE FROM DEVELOPMENT TO OPERATIONS}

The expanded U.S. geothermal industry is moving rapidly from the development period into the operating stage, and the people who are taking over are displaying all of the ingenuity and determination to make it work that the pioneer entrepreneurs brought into the field three decades ago. This was certainly evident at the Geothermal Resources Council's "Update on Geothermal Power Plants in the Western United States and Selected Direct-Use Operations," which was held in Sparks, Nevada, in April 1989. The session drew 225 registrants with more than $\mathbf{4 0}$ speakers among them, each with an interesting story to tell. David N. Anderson, executive director of the GRC, was surprised at the turnout and so enthused by the interest in the session that he promised to repeat the event, perhaps twice a year.

The impression left by the session is that alert operators and early appraisal of difficulties, together with the application of imaginative and innovative procedures, will be demanded by geothermal plants once they become operative. Since physical characteristics and fluid composition and temperatures, both of the brines and the ambient air, differ from site to site, solutions to problems often will be site-specific. However, information exchanges such as those encouraged by the GRC program in Sparks will provide new ideas and applications that can be helpful within the industry.

Anderson told the group that for future sessions he might narrow the subject to specific problem areas for greater depth and sharper focus. A poll was taken, results to be announced later, to help guide the development of future meetings.

Source: Geothermal Report 5/1/89

\section{GEOTHERMAL INDUSTRY LOOKING TO FOREIGN MARKETS}

Assisted by federal and state funding, the Geothermal Resources Council (GRC) and a newer industry group called the National Geothermal Association (NGA) began several years ago to take action to protect the investments of the U.S. geothermal industry until domestic power demand increases. This action responds to the call of GRC's Executive Director David N. Anderson to Geothermal Program Review V in Washington in April 1987: "If we can't use the greatest geothermal expertise in the history of the world at home, let's do the next best thing -- sell it internationally."

Federal assistance has been provided by the Department of Energy (DOE), the U.S. Agency for International Development (AID), and the Trade and Development Program (TDP), an independent agency of the government, through their membership in the Committee on Renewable Energy Commerce and Trade (CORECT). CORECT is an interagency group established by the Renewable Energy Industry Development Act of 1983. Its mandates include streamlining federal export assistance mechanisms, improving the education of buyers and sellers, and facilitating financing for renewables sales overseas. It is chaired by DOE.

State support has been provided by the Energy Technology Export Program of the California Energy Commission (CEC). CEC acts as a facilitator or "marriage broker" to match international buyers with California energy firms which supply technology and energy project development experience. The Commission can be particularly effective in this role for the California industry since, in most countries, energy development is controlled by government agencies and import business is typically conducted or enhanced by government-togovernment relations.

\section{Need For Export Assistance}

Due to the sharp decline in oil prices and an energy glut in the "geothermal" states, growth in the geothermal industry has been considerably impeded. The industry has been by no means stagnant, and most contracts for power sales are being used by new plants. However, the backlog of Standard Offer contracts in California will disappear by 1990, and unless the market for power increases, domestic activity in all geothermal states will be extremely limited. 
Why has the international movement been initiated only recently? Anderson supplied several reasons in his 1987 Program Review V address:

1) Up until 1985, there was no integrated effort to sell U.S. geothermal technology abroad.

2) A major portion of the U.S. firms involved in geothermal development is virtually unknown abroad.

3) Many U.S. vendors were totally engrossed in sales and services to the domestic market and paid little attention to the possibility of developing international sales.

4) The value of the dollar was so high that only a few countries could afford the high quality goods and services that the U.S. had to offer.

5) Many firms were newly formed and had not developed the expertise to do business internationally.

While there is a large potential international market for geothermal equipment and services - CORECT's estimate in 1986 was $\$ 14.5$ billion by 1990 -- the U.S industry did not share the competitive advantages provided to exporters in other countries. Recognizing the trade opportunities of renewable energy technologies, many nations were ahead of the U.S. in stepping up their trade development efforts and aggressively subsidizing and encouraging renewable energy exports. Their governments often provided liberal financing through export subsidies and mixed financing packages.

While there are over 100 federal programs in this country that provide various types of support to U.S. exporters, the young geothermal industry had little reason to know what type of assistance was available through which agency, who was eligible, or how to proceed. It is now CORECT's responsibility to coordinate the activities of these programs and inform the renewable energy industries of the services available.
Major Activities To Date to Promote Geothermal Overseas Markets

- United Nations Workshop on the Development and Exploitation of Geothermal Energy in Developing Countries, Reykjavik, Iceland, September 1986. CORECT sponsored the attendance of three U.S. geothermal industry representatives and Ronald R. Loose, Director of DOE's Office of Renewable Energy Technologies. The industry attendees presented papers on various aspects of the U.S. industry's capabilities in geothermal equipment and services, and Mr. Loose discussed the opportunities for international students in the U.S. research and development program.

- Conference to Promote International Sales of Geothermal Equipment, sites in California and Nevada, October 1987. The first of its kind in the U.S., the conference is more appropriately termed a reverse trade mission. It was jointly sponsored by CORECT, CEC, and GRC. The World Bank also provided support. Twenty-three decision-makers representing 18 developing countries attended. The conference included site visits to major U.S. geothermal projects, a "mini" exhibition of U.S. equipment and technology, and round-table workshops featuring U.S. companies offering geothermal products and senvices to the international market. To qualify for participation in the conference, it was mandatory that U.S. companies manufacture their goods in the U.S. and use the U.S. as their primary base for sales of products and services.

- U.S. Geothermal Trade Mission to Kenya, June 1988. TDP and NGA sponsored attendance of four U.S. industry members and representatives of DOE and the Overseas Private Investment Corp. (OPIC) in response to 
the announced intent of the Kenyan government to expand that nation's geothermal power generating capacity. The National Power Development Plan calls for staged development of 260 MWe by 2005 at an estimated total cost of over $\$ 350$ million.

- Workshop on Export Financing and Marketing, Los Angeles, February 1989. This NGA workshop was the first geothermal export financing and marketing course that addressed the critical problems of U.S. exporters. The emphasis of the course was on the finalization of national strategy, the solution of specific problems, and the development of a consortium of vendors. Concentrated information on geothermal markets in Central America was provided.

- Reverse Trade Mission: 1st Session, Geothermal Well Drilling and Development, Imperial Valley, California; 2nd Session, Small Power Plant Development, sites in California and Nevada, May-June 1989. A survey of participants in the 1987 reverse mission identified the topics of these sessions as major concerns in geothermal development in developing countries. The visitors were carefully selected for good representation of both technical knowledge and an adequate level of decision-making authority. Approximately 12 people -- representing the Philippines, El Salvador, Guatemala, Costa Rica, Honduras, and Kenya -attended each session of the mission. Sponsors included CORECT, CEC, and GRC.

- $\quad$ Trade Mission to Central America, June 1989, sponsored by GTD, CORECT, and LANL. Seven representatives of the U.S. geothermal industry visited Costa Rica, Guatemala, El Salvador, and Honduras for two weeks. The group was led by a bilingual native of the region and was assisted by a Washington, D.C., attorney knowledgeable in international law, trade policies, and financing. The group identified target projects to be ranked in order of priority and will recommend one or two for action by a team of U.S. geothermal industry partners. The focus of these efforts is to develop a "flagship" or showcase for demonstrating success in U.S. technology and competitive financing for overseas projects.

CORECT related publications include:

1. List of U.S. Companies Selling Goods and Services Internationally, compiled by GRC.

2. United States Geothermal Technology: Equipment and Services for Worldwide Application, prepared by Meridian Corp. under subcontract to the Idaho Nationai Engineering Laboratory.

3. Review of International Geothermal Activities and Assessment of U.S. Industry Opportunities, prepared by Meridian Corp. under subcontract to the Los Alamos National Laboratory.

For further information on CORECT activities, please contact:

Ralph Burr

Geothermal Technology Division

U.S. Department of Energy

1000 Independence Avenue, SW

Washington, D.C. 20585

202/586-5335

Robert Annan

CORECT Staff Director

Photovoltaic Technology Division

U.S. Department of Energy

1000 Independence Avenue, SW

Washington, D.C. 20585

202/586-1720 


\section{GEOTHERMAL ENERGY -- AN ECONOMIC AND ENVIRONMENTAL BARGAIN, SAYS CALIFORNIA ENERGY'S CONDY}

In an address to the Interagency Geothermal Coordinating Council (IGCC) in April 1989, Charles T. Condy, Chairman and Chief Executive Officer of the California Energy Co., called geothermal energy "the fuel of the future." Noting that new power plants will be needed during the coming decade, either because of new demand or old plant replacement, Condy said the plants built to meet these demands will have to be both economical and environmentally benign; geothermal plants are bargains in both categories."

To support this contention, Condy pointed out that with all nine (Coso) units running at an assumed 92 percent capacity factor, we expect to generate 1.85 billion kilowatt hours of electricity in 1990 at...a levelized cost of 4.6 cents per kilowatt hour in constant dollars amortized over a 30 -year operating period...and we believe that we have developed a model project, a power plant that stands as incontrovertible proof that we can exercise environmental restraint and still have economic prosperity." He was referring to his company's complex of four dual flash plants at Coso Hot Springs in California's Mojave Desert, which employs a new technology in which all noncondensible gases are injected to the subsurface along with spent brines.

This means, he said, that the amount of carbon dioxide released at Coso "is virtually nothing...less than 1,600 hundred pounds per megawatt per year, compared to more than 13 million per megawatt from an oil-fired plant, and more than 10 million from a gas-fired plant." Or, put another way, Condy said "it would take 3.5 million barrels of oil per year to run an oil-burning plant the size of a fully operational Coso, and it would release more than 3 billion pounds of $\mathrm{CO}_{2}$ into the atmosphere." During its 30 -year lifespan, he noted, the Coso project will reduce:

- the oil import deficit by 105 million barrels;

- $\quad$ the trade deficit by $\$ 4.8$ billion; and
- the clean air deficit by 90 billion pounds of $\mathrm{CO}_{2}$.

The Coso project has received recognition from both the Environmental Protection Agency and the California Energy Commission.

The IGCC, established by the Geothermal Research, Development, and Demonstration Act of 1974, meets annually in Washington, D.C. It is chaired by the Department of Energy.

\section{MAGMA ANNUAL REPORT PAINTS POSITIVE PICTURE}

Magma Power Company of San Diego, California, cited in its annual report for 1988 a 223 percent increase in its generating capacity, a 30 percent increase in total revenue (to $\$ 26,025,000$ ), and a 70 percent increase in net income (to $\$ 9,280,000$ ) before asserting that 1989 and 1990 would be a time "to digest" its rapid growth.

"Our company has been likened to a man who has eaten a banquet," Arnold L. Johnson, president and CEO, and Andrew W. Hoch, chairman and chief operations officer, told shareholders in the report's opening letter. "Now he needs time to digest. So does Magma."

After recounting steps taken and being taken to make economies in operating three large plants at a single location (the Salton Sea KGRA), Johnson and Hoch said, "While we realize these efficiencies and aggressively seek out more, we are reaching for a new peak of profitability. Once achieved, we will be securely positioned for new investments for the 1990s."

The Elmore and Del Ranch plants were brought on-line during 1988, and the Leathers plant was 50 percent complete. These plants and the Vulcan plant, the first Magma venture in the Salton Sea area, are each owned by separate limited partnerships in which Magma, through its subsidiaries, has a 50 percent interest. The other 50 percent of each is owned by Mission Energy Co., of Ivine, California, through subsidiaries. Mission itself is a subsidiary of SECorp, which is also the parent company of Southern California Edison Co., to which the energy from all of these plants is sold under Standard Offer No. 4 contracts. 
Mission acquired its 50 percent interest in the Vulcan plant in December 1988 when it bought the stock of BNG Geothermal, Inc., a Vulcan partner, from BNG's parent, Burlington Northern, Inc. Red Hill Geothermal, Inc., a wholly owned Magma subsidiary, is operator of the Elmore, Del Ranch, and Leathers plants. Vulcan Power Company, also wholly owned by Magma, is operator of the Vulcan plant.

An interesting note: The Vulcan plant, the only one to operate through the whole of fiscal year 1987, produced an average of 105 percent of contract capacity (29.5 MW) in that year and returned as Magma's share $\$ 11,502,000$.

Source: Geothermal Report 7/1/89

\section{CASA DIABLO PLANT HONORED}

The Ben Holt Company of Pasadena has been awarded the Engineering. Project Achievement Award by the Institute for the Advancement of Engineering for the design and construction of the $8 \mathrm{MWe}$ Mammoth-Pacific Geothermal Power Plant at Casa Diablo Hot Springs near Mammoth Lakes, California. The Institute is an association of engineering societies based in southern California. The plant is owned by Pacific Energy and is on land leased from Magma Power Co. The energy is sold under contract to the Southern California Edison Co.

Ben Holt, president of the company, said the Casa Diablo Plant is the world's first commercial air-cooled binary cycle geothermal power plant. Built in 1984, it has been operating successfully ever since its shake-down tests. Superheated water is pumped from 600 feet and gives up its heat in tubular heat exchangers to a secondary working fluid (isobutane), which drives the turbine. All of the cooled geothermal fluid is reinjected. The isobutane vapor from the turbine is condensed in air coolers, and the liquid is pumped back into the tubular exchangers to close the loop. Holt is proud of the fact that the plant is emissions-free and requires no consumptive use of water. It presents a low profile, he said, and is well suited for the environmentally sensitive area.

Source: Geothermal Report 5/2/88

\section{FIRST U.S. HOT WATER PLANT UNDER NEW OWNERSHIP}

After acquiring the $13.4 \mathrm{MWe}$ B. C. McCabe binary power plant, the first hot water plant in the U.S., and other properties at East Mesa from Magma Power Co., Geothermal Resources International (GEO) has retained only 50 percent ownership. A subsidiary of Mission Energy Co. purchased a total of 50 percent interest in December 1988 from GEO and Pacific Corp. Financial Service which had earlier assumed a 30 percent equity interest in the East Mesa project. The holdings of the GEO East Mesa Limited Partnership now includes:

- approximately 4,200 acres of geothermal leaseholds,

- $\quad$ a new 37 MWe dual flash steam plant completed in 1989 and the McCabe plant, both of which sell power to SCE; and

- an outstanding long-term Standard Offer No. 4 contract with SCE.

In the event that the East Mesa project is expanded with an additional plant of up to 36 MWe, the Mission Energy subsidiary has the option to participate in the project, including providing funding for $\mathbf{a} \mathbf{5 0}$ percent interest.

Sources: Geothermal Report 1/16/89, Geothermal Resources Council Bulletin $1 / 89$

\section{ORMAT MAKES NEWS ON MANY FRONTS}

Ormat Energy Systems Inc. (OESI), a subsidiary of an Israeli corporation, now operates geothermal power plants at four locations in Nevada and at East Mesa in California, and is planning new ventures at Heber and in Hawail. Using its own small binary units, OESI has demonstrated the profitability of generating geothermal power with less than the highest 
quality resources, both with very small capacity plants and with larger aggregations of the small units.

The largest Ormat facilities are at East Mesa. They include Ormesa I, a 30 MWe plant consisting of 26 1.2-MWe binary units, financing for which was guaranteed by the DOE Geothermal Loan Guaranty Program; Ormesa II featuring 20 identical modular units; and Ormesa IE, which will average about $9.5 \mathrm{MWe}$. A fourth plant, Ormesa $\mathrm{IH}$, is under construction. Harbert International is a partner in Units $\mathrm{I}$ and $\mathrm{IH}$.

Ormat's holdings in Nevada include:

$\begin{array}{lc}\text { KGRA } & \begin{array}{c}\text { Capacity } \\ \text { MWe (gross) }\end{array} \\ \text { Steamboat Springs } & 7.4 \\ \text { Stillwater/Soda Lake } & 3.6 \\ \text { Stillwater/Soda Lake } & 11.0 \\ \text { San Emidio Desert } & 4.8\end{array}$

The company has purchased the rights of the Puna Joint Venture to build a $30 \mathrm{MWe}$ plant on the island of Hawaii. The plant will represent the first privately owned and operated commercial geothermal project in the state of Hawaii. The original partners were Maxus Energy, parent company of Thermal Power, and Amfac Energy.

More recently, at the end of background material released at the June 11,1989 , dedication of its Stillwater plant, Ormat announced that "together with Centennial Energy and ERC International, Ormat has acquired the rights to develop a $44 \mathrm{MWe}$ binary plant" at the site of the closed Heber Binary Demonstration Plant. The note added that "Chevron Resources controls the resource, and negotiations have commenced to discuss what role it will play in the project." Ormat said the project has a Standard Offer No. 4. SCE contract good until April 1991.

Ormat representatives pointed out to the Geothermal Report that the binary system that it uses so successfully at East Mesa -- Ormàt Energy Converter Modules that use the organic rankine cycle -- is different from that of the existing Heber binary plant. Ormat believes that it can install a series of its OECMs in time to meet the S.O. 4 deadline if the negotiations can be completed soon.
Ormat's U.S. operations are directed out of its Sparks, Nevada, facilities.

Source: Geothermal Report 7/1/89 and others

\section{UNOCAL CHIEF PLUGS GEOTHERMAL}

In addition to giving the specifics on the newly operational Salton Sea Unit 3, UNOCAL Corp.'s President and CEO Richard Stegemeier took advantage of the dedication ceremonies for the unit to go to bat for geothermal energy in general.

"Geothermal energy is a relatively clean and cost-effective energy alternative," Stegemeier said. "This fact tends to be forgotten these days, as many people seem to take relatively cheap and plentiful oil supplies for granted. The U.S. is the world's largest consumer of petroleum, yet we have less than 3 percent of known reserves.... By the mid-1990s, America's oil-import level is expected to exceed 50 percent, the highest level in our history. Geothermal power can help bolster America's energy supplies. And, unlike coal or crude oil, it can do so without producing undesirable air emissions. We still have a significant amount of electrical energy waiting to be recovered from geothermal resources in the United States....

"The growth of geothermal energy here in the Imperial Valley and throughout the country, depends on continued long-term investments in exploration, research, and development. Typically, we need 5 to 10 years to develop a newly discovered geothermal field into a source of electricity. In other words, the geothermal fields we discover today could be providing electric power...exactly when we may need it the most."

In closing, Stegemeier said, "Nature supplies the heat of the earth -- we supply the technological expertise to make it do our bidding. Through the combined efforts of energy companies, public utilities, and the government, we can develop and use this valuable energy source for generations to come."

Source: Geothermal Report 6/1/89 


\section{CALIFORNIA ENERGY'S PATH TO DIVERSE SOURCES OF CAPITAL.}

(The following paragraphs are extracted from an article in the April 1989 issue of "Corporate Finance" by Douglas Bartholomew. This material and the following brief article are printed here to illustrate 1) the difficulties in obtaining major financing for geothermal development that have existed, and 2) the more recent increase in investor willingness to support geothermal projects.)

For the last 10 years, Charles Condy, founder, chairman, and CEO of tiny California Energy, has been searching for financing to build a 230megawatt geothermal power plant at Coso Hot Springs in California's Mojave Desert. "When I first started this enterprise," he says, "I thought I was going to be financed by Beneficial Finance at 35 percent."

Under the circumstances, he might have been grateful to have gotten even that. California Energy's fiscal track record is written mostly in red ink. It just ended its sixth consecutive year of losses, reporting a \$258,000 deficit for 1988. Except for consulting fees, the company had no operating revenues at all until the second half of 1987. And at the end of that year, its stock, traded on the American Stock Exchange, had a total market capitalization of just $\$ 50$ million.

When you tell bankers...that you are going to drill holes in volcanoes and the desert and that you need $\$ 600$ million, they just stare at you," Condy says. "Now where does a company with a negative net worth get financing in the Eighties?..." Condy mined partnerships, venture capitalists, private equity markets, and vendor financing to keep his dream alive. He scratched up nearly $\$ 100$ million this way, enough to drill some wells, buy a turbine, and build a generating plant on the property he had leased for 30 years from the U.S. Navy which had a weapons testing site there.

And he eventually used (guaranteed sales contracts with SCE with escalating prices over 10 years) as collateral to bootstrap his way into a loan package. But he didn't get it from any
American bank. The project financing, the first ever to finance steam in the ground, is coming from the unlikely quarters of Credit Suisse, a Swiss money center bank.

Last August, after advancing \$66 million in 1987, Credit Suisse committed half a billion dollars to the project.

(In 1980 when) the company essentially had no funds, Caithness Corp. was the first rescuer. A private New York company that invests in a variety of energy development projects, Caithness had soured on uranium and was looking to (invest in) geothermal. Caithness put up $\$ 45$ million to $\$ 50$ million in exchange for a half interest in the three generating units that constitute the (initial) project. When we got involved in 1980," says Caithness Chairman James Bishop, "geothermal was still very attractive from a tax standpoint." Caithness also tapped Florida Power and Light, Public Service Electric \& Gas, and Dominion Electric for investments in the three Coso partnerships.

Other early sources of capital were Venrock Associates, the Rockefeller venture capital firm, and the New York investment banking firm of Allen \& Co. Venrock made both a loan and an equity investment with a portion of the loan later converted to additional equity and the rest repaid in cash. "Allen \& Co. injected $\$ 500,000$ into the company and made us comfortable at a time when we really needed it," Condy says.

California Energy hit a dry financing hole from 1982 to 1985 . To get through the lean years, Condy (went) to London, and sparked sufficient interest to bring home more than $\$ 11$ million via private equity placements with several U.K. investment trusts.

Then in 1986 the financing began to come together. Condy first arranged a vendor-financing package with Guy F. Atkinson Co. in San Francisco (construction) and Mitsubishi Heavy Industries (turbines) in Tokyo. Nonetheless, the turnkey financing contract...was hardly advantageous. To sweeten the deal, California Energy agreed to give the contractor 10.3 percent of the revenues from the first turbine for 20 years. "We took the joint venture financing in 1986 because we couldn't get a bank loan,' CFO Richard Nishkian says. 
California Energy went public in 1987. After that, the company was able to access diverse sources of capital. Its initial public offering in March of that year was underwritten by Laidlaw Adams \& Peck (now Laidlaw Holdings). The offering was for 1.9 million shares, plus an overallotment of 285,000 shares fully subscribed at $\$ 7.50$ per share, yielding $\$ 13.9$ million to the company.

The company used fresh project financing from Credit Suisse to buy out Atkinson's revenue sharing rights. The Swiss loaned the company its first piece of takeout financing - $\$ 66$ million - in June 1987 but California Energy needed an additional $\$ 18$ million - closed last October -- to complete the takeout. In March 1988, the company privately placed $\$ 30$ million in senior debt to continue much-needed drilling to fully develop the Coso field. Once adequate steam reserves were proven, Credit Suisse took the plunge. The bank made the final commitment in August for an additional $\$ 438$ million for eight additional turbines, and a total of $\$ 504$ million to the project.

The buyer of the March private placement, handled by Merrill Lynch, was Principal Mutual Life Insurance of Des Moines. The $\$ 30$ million, seven-year unsecured note yields 12 percent plus 10 percent of cash flow from the Coso project for five and a half years beginning in late 1990. With no cash flow to start, California Energy will roll the first three interest payments into the principal, making the note worth $\$ 36$ million.

In order to survive, the company had no choice but to accept these unattractive financing terms. We're used to paying these extremely high rates to raise money for drilling, "Condy says stoically. "After Credit Suisse did the first financing, I thought we'd still be in the junk bond range of 18 to 19 percent money. But they came right back to lend us the money for the whole thing at the London Interbank Operating Rate plus 1.5 percent."

FOOTNOTE: As GPM went to press, California Energy announced record company revenues and profits in the second quarter of 1989. With five plants in operation, the June revenues from the Coso project were $\$ 10$ million. The company's share amounted to $\$ 4.8$ million or $7 \notin$ per share.

\section{F I N A C I A L MARKET S PARTICIPATING IN GEOTHERMAL DEVELOPMENT}

Except for the major integrated oil companies involved in geothermal development, it is rare that a geothermal company is able to finance full equity for power plants on its own. However, in recent years, financing for U.S. geothermal projects has become more generally available, although not in the magnitude of the funds lent to California Energy. That is still a oneof-a-kind venture in this industry.

A variety of mechanisms are used for funding geothermal development. According to press reports, these include construction loans, non-recourse loans, debt financing, leveraged leases, sale/leasebacks, and term loans. Financial houses that have participated in recent projects include:

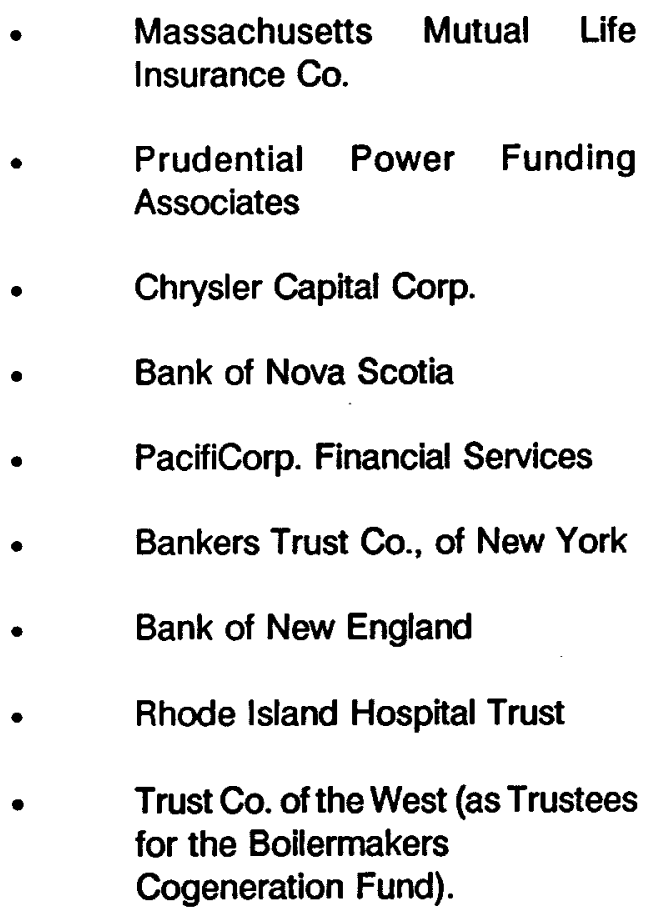

- Massachusetts Mutual Life Insurance Co.

Cogeneration Fund). 


\section{GRC KEYNOTE ADDRESS PAINTS POSITIVE PICTURE}

In his keynote address to the 1987 Geothermal Resources Council annual meeting in Sparks, Nevada, Ronald P. Baldwin, chief executive officer of Geothermal Resources International, painted a positive picture of industry progress with "5,000 MWe of electricity being generated worldwide [and] many more plants scheduled to be on line in the next decade. In addition, consumption of thousands of megawatts of electric power is being avoided by direct use geothermal applications."

Although the title of his address, "A Mature Energy Source Faces Overabundant Energy Supplies," did not promise a rosy recitation, Baldwin refused to be a nay-sayer. He was particularly enthusiastic about hot dry rock, which, he said, the industry is on the brink of using "as a method of creating electric power without the necessity to locate already existing underground fluids." The possibility of being able to operate hot dry rock geothermal fields certainly "will further expand geothermal into areas not previously contemplated."

Technical advances have increased "the diversity and extent of geothermal resources as an electrical power source," including 1) use of remote sensing of geothermal fields, 2) improvements in techniques and reductions in cost of deeper drilling, 3) improvements in operations of developed and developing geothermal fields, and 4) more frequent utilization of modular plant systems. Baldwin also cited improvement both in the elimination of noncondensible gases from the steam flows and the abatement of hydrogen sulfide.

Acknowledging the start-up of major nuclear plants in California and Arizona, which "has caused a temporary situation of excess capacity," Baldwin focused on a future where energy would again be in short supply and where "geothermal energy plants should be able to produce power at much lower costs, in fact, probably half the price of present nuclear plants."

Source: Geothermal Report 11/2/87

\section{COSO DEVELOPMENT NEARING COMPLETION}

Beginning with Navy Power Plant No. 1, Unit No. 1, completed in July 1987, the California Energy Co. has pursued an ambitious construction schedule at the Coso geothermal field. Described as "the first phase at Coso" by Chairman Condy, the 9-unit, 230-megawatt complex is nearing completion.

On April 7, 1989, when Condy addressed the company's shareholders, five units were on line, a sixth was set to begin operation in July, and completion of the other three, for which materials were procured in advance, was expected before the end of 1989. Two of the plants, Navy Power Plants 1 and 2, are located, as their name implies, on the property of the Naval Weapons Center and contain three turbine units each. There are also two plants on nearby land leased from the Bureau of Land Management; BLM East which consists of two turbine units and the one-turbine BLM West. (See power plant tables:)

Through its contracts with California Energy, the Navy realizes a direct reduction in its utility bill and receives a substantial percentage of the gross revenues of the plants on its property. The percentage escalates on a sliding scale over 20 years.

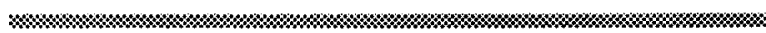
WHILE NEW PLANTS OPEN AT THE GEYSERS, OPERATORS REPORT SERIOUS PRODUCTION PROBLEMS; DOE OFFERS R\&D ASSISTANCE

While four new plants totalling about 200 MWe began operation at The Geysers in 198889. (see tables at the end of this section) field operators and utilities have advised the California Energy Commission of a serious steam production decline at the field. As of the September 21, 1989, CEC hearing, Pacific Gas \& Electric Co., owner of 68 percent of the nearly 2,000 MWe on line, testified to "a steam shortfall of more than $300 \mathrm{MWe}$, or about 22 percent of our installed capacity." A spokesman for Unocal, steam supplier for 16 of the 28 plants at the field, 
reported that peak steam production on Unocal leases was approximately 19 million pounds per hour, but is now $15.5 \mathrm{Mlb} / \mathrm{hr}$, for a decline of about 18 percent. Decline is reportedly widespread over the field, but the rate appears to vary from area to area.

Other technical problems hindering operations at The Geysers have been reported including pressure decline, an increase of hydrogen chloride in the steam in the northwest part of the field, and an increase in noncondensible gases in the western portion. Increased noncondensibles and hydrogen chloride "go hand in hand in some wells," operators report.

These difficulties were the subject of an informal meeting called by Dr. John E. Mock, director of DOE's Geothermal Technology Division, at the close of the Geothermal Resources Council annual meeting in Santa Rosa, California, in October 1989. The meeting was attended by over 60 representatives of Geysers field operators, utility plant owners, national laboratories and other research facilities, and the U.S. Geological Survey.

Mock stated that he had called the meeting to offer DOE's help in finding solutions to the problems at The Geysers. He emphasized that it is not DOE's intent to intrude in industry planning, but to act as a "facilitator" in R\&D projects that are agreed to as elements of a cooperative research strategy.

The Division has allocated $\$ 1$ million to the task for fiscal 1990, but Marshall J. Reed, GTD's Reservoir Technology program manager, pointed out that these funds will not go far. He and Mock both emphasized that "cost-sharing and/or tasksharing with industry is absolutely essential."

A consensus was reached that the development of a comprehensive model of the field and an optimum injection strategy are critical for field improvement. Much of the technical discussion centered on the need for all avallable field data to support a reliable model or models and available methods for monitoring injectate behavior. The services of the Oak Ridge National Laboratory were enlisted to conduct studies on the derivation of the unusual hydrogen chloride loadings.
Rather than seeking a completed research strategy at the meeting, Mock asked for written communications from interested parties within $\mathbf{3 0}$ days. He requested that these communications prioritize research projects, identify long-term research needs, and outline offers of participation in terms of wells to be used for testing, surface equipment, personnel, and research expertise. Another meeting will be held to finalize research strategy.

Federal funding of individual R\&D tasks will be provided through the existing mechanisms of the Geothermal Drilling Organization or the Geothermal Technology Organization. The charter of these groups calls for at least $\mathbf{5 0}$ percent project funding by industry, but avoids some of the more onerous aspects of federal contracting and facilitates the movement of matching funds from DOE to a specific project.

Michael Smith, a representative of the California Energy Commission, stated at the Santa Rosa meeting that the Commission would like "to play a very important role" in The Geysers effort and offered funding from the state's geothermal grant and loan fund. Since allocation of these funds must go through local governments, Smith recommended that Sonoma and Lake Counties, site of The Geysers field, work closely with industry on formulating the financial and technical approach to be presented in their application for funding.

The Commission is also continuing to consider the implications of the production decline at The Geysers in electricity forecasts for the state and other aspects of state energy policy.

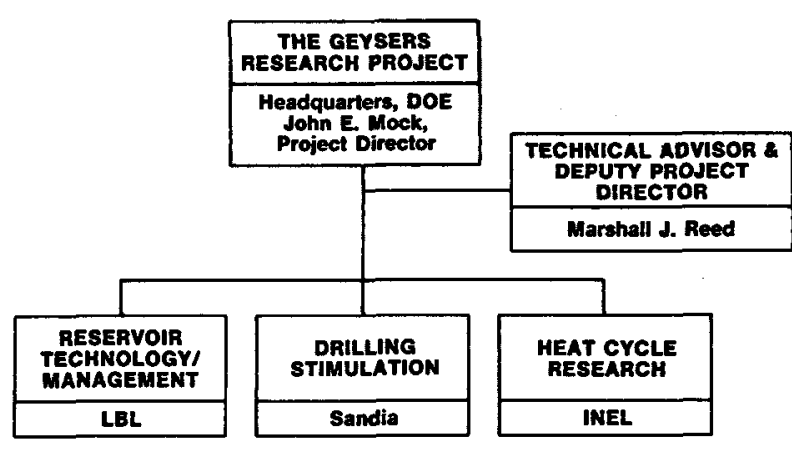

DOE MANAGEMENT TEAM FOR THE
GEYSERS RESEARCH PROJECT 


\section{GEOTHERMAL DIRECT USE PROJECTS FOUND IN 44 STATES}

A new survey by the Geo-Heat Center at the Oregon Institute of Technology identified geothermal direct use projects in 44 states. Significant growth in these applications has occurred in the last 10 years. The total installed capacity is 5.7 billion Btu per hour, or 1,700 thermal megawatts, with an annual energy use of nearly 17,000 billion Btu, or the equivalent of 4.5 million barrels of oil.

These applications include space conditioning of buildings, district heating, geothermal heat pumps, greenhouse heating, industrial processing, agriculture, and swimming pool heating. Historically, small resorts and limited space and district heating systems accounted for most direct heat applications, but in the 1980's, geothermal heat pumps for space heating and cooling comprise the fastest growing segment of the market. Commercial greenhouses and fish farms are also rapidly increasing in number.

The Geo-Heat Center estimated that almost 80,000 geothermal heat pumps are in use in the U.S., and an additional 18,000 systems were installed 1988. The current growth rate is in excess of 25 percent annually. The popularity of these systems is attributed to the recent promotion by electric utilities throughout the country to level seasonal load patterns and decrease peaking demand. Geothermal heat pumps have national appeal since they do not require resistance heating as air source heat pumps do when temperatures drop below the -7 to $-1^{\circ} \mathrm{C}\left(20\right.$ to $\left.30^{\circ} \mathrm{F}\right)$ range.

A number of commercial crops can be grown in greenhouses, making geothermal resources particularly attractive in cold climates. Potential crops include vegetables, flowers (potted and cut), house plants, and tree seedlings. Economics of geothermal greenhouses are subject to a number of variables such as the type of crops, climate, resource temperature, and type

\section{GEOTHERMAL RESOURCE DEVELOPMENT IN THE UNITED STATES}

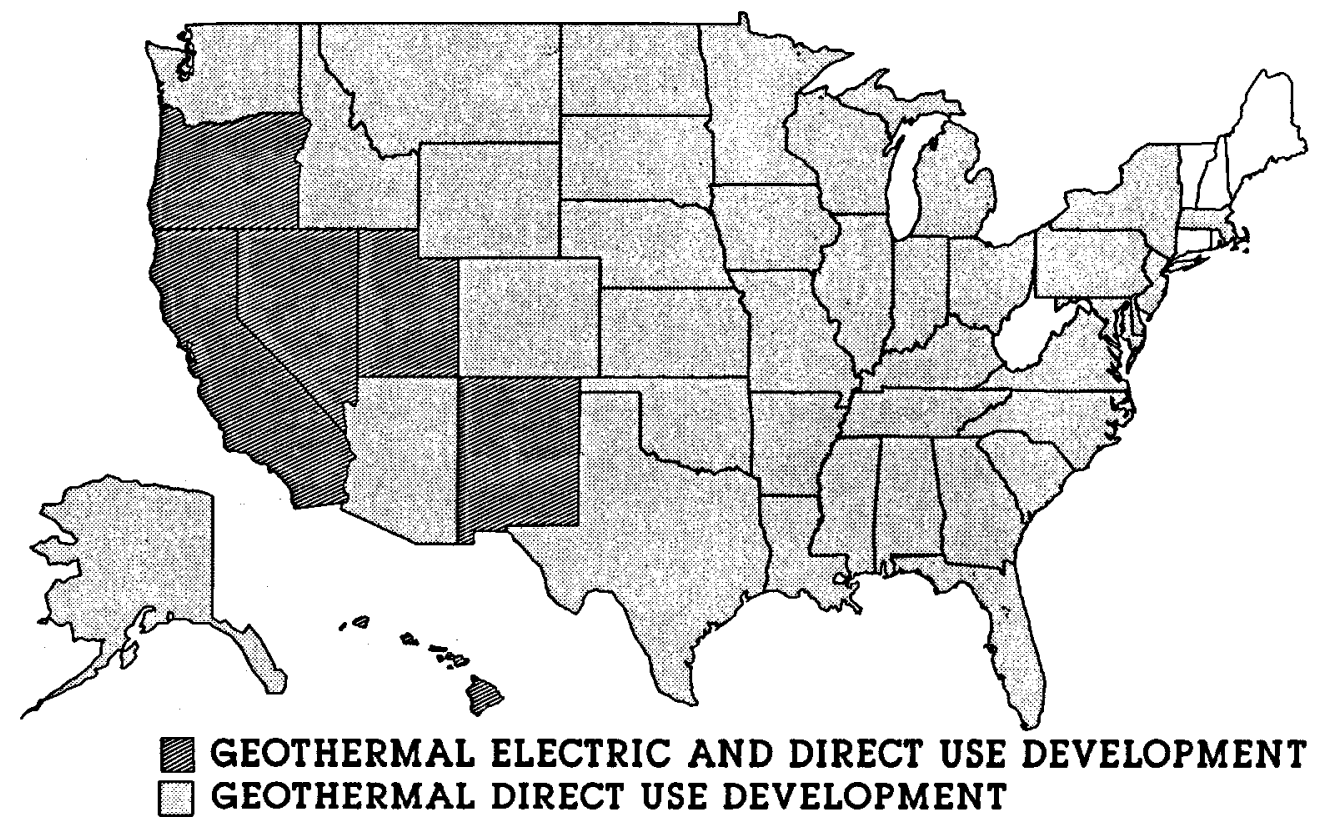


of structure. However, reductions in heating costs range from 30 to 50 percent and more. For example, heating costs are reduced by 80 percent in a 75,000 square foot greenhouse for growing roses near Helena, Montana. The Geo-Heat Center reports that 35 commercial geothermal greenhouses are in operation in 12 states. Many are expanding, some doubling in size.

The benefit of a controlled temperature environment in geothermal aquaculture operations enhances production rates, increasing fish growth rates by $50-100$ percent and increasing the number of harvests per year. The optimum resource temperature for fish farming varies with the species grown, with catfish reaching maturity in 4-6 months at $18-24^{\circ} \mathrm{C}\left(64-75^{\circ} \mathrm{F}\right)$; trout in $4-6$ months at $13-18^{\circ} \mathrm{C}\left(55-64^{\circ} \mathrm{F}\right)$; and prawns in $6-9$ months at $27-30^{\circ} \mathrm{C}\left(80-86^{\circ} \mathrm{F}\right)$. Currently, geothermal fish farms are in operation in Arizona, California, Idaho, Nevada, and Oregon. In most cases, these operations would not be economic without geothermal use.

The distribution between district heating and space heating is that in the former, heat (hot water or steam) is distributed from a central location through a network of pipes to multiple structures while space heating usually involves one well per structure. The potential for geothermal district heating in the U.S. is very large. An inventory identified a total of 1,277 hydrothermal sites within five miles of 373 cities in eight western states with a combined population of nearly seven million. Currently 23 geothermal district heating systems are in operation.

An important consideration in district heating projects is the thermal load density, or the heat demand divided by the ground area of the district. A high heat density is required to make district heating feasible, since the distribution network which transports the hot water to the consumers is expensive. Although geothermal district heating systems are capital intensive, operating expenses are low with typical savings to consumers ranging from about 30 to 50 percent of the cost of natural gas.

Space heating and domestic hot water supply are exemplified by the use at the Peppermill Casino in Reno, the largest of this type of application, and the $\mathbf{5 0 0}$ individual homes that utilize downhole heat exchangers in Klamath Falls, Oregon.
The Geo-Heat survey identified 114 resorts using geothermal energy, the largest being Paynes Fountain of Youth and Hot Springs State Park in Wyoming. In some cases, elaborate facilities have been developed.

Most industrial geothermal applications require higher fluid temperatures. Examples of use in this country include:

$$
\begin{aligned}
& \text { - enhanced oil recovery }-93^{\circ} \mathrm{C}\left(200^{\circ} \mathrm{F}\right) \\
& \text { - } \text { heap-leaching operations to extract } \\
& \text { precious metals }-110^{\circ} \mathrm{C}\left(230^{\circ} \mathrm{F}\right) \\
& \text { - mushroom growing }-113^{\circ} \mathrm{C}\left(270^{\circ} \mathrm{F}\right) \\
& \text { dehydration of vegetables }-132^{\circ} \mathrm{C} \\
& \left(270^{\circ} \mathrm{F}\right) .
\end{aligned}
$$

Geothermal Food Processors near Fernley, Nevada, has been in operation since 1978 dehydrating onions, garlic, celery, and carrots. The geothermal heat replaces natural gas for a savings of about $\$ 350,000$ per year. (See following article on new geothermal use in Nevada gold mines.)

In summary, the Geo-Heat Center points out that direct use of geothermal energy in the U.S. is recognized as an alternative energy application that has proven itself technically and economically.

The Geo-Heat Center conducts the DOEsponsored Geothermal Research and Development Assistance project. It provides services to users and potential users that include feasibility studies, investigations on equipment and materials performance, economic analyses, and data bases and pertinent publications.

\section{NEW USE OF GEOTHERMAL HEAT IN GOLD MINING RESULTED FROM UNIVERSITY OF NEVADA STUDY-- R\&D TO CONTINUE}

As a result of a University of Nevada, Las Vegas Division, study on the use of geothermal heat in gold and silver heap-leaching operations, two Nevada mines have independently begun using geothermal fluids in this process. Pegasus 


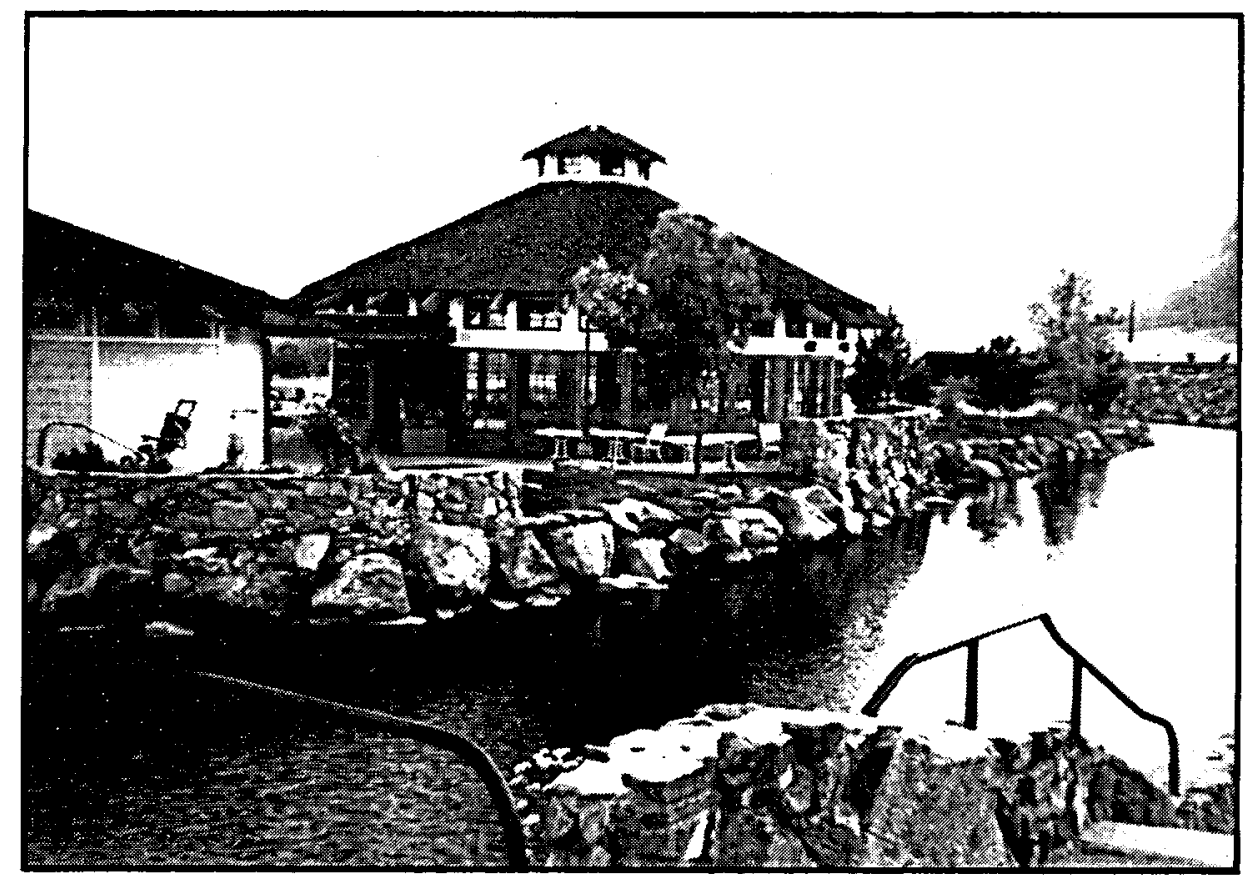

The Walley Hot Spring Resort, 50 miles south of Reno, utilizies natural geothermal springs and wells for several direct heating uses - large swimming pools, soaking pools, spas, and domestic hot water and space heating for an "upscale" hotel. The temperature of the spring water is $43^{\circ} \mathrm{C}\left(110^{\circ} \mathrm{F}\right)$, and the wells flow at $71^{\circ} \mathrm{C}\left(160^{\circ} \mathrm{F}\right)$.

Gold Corp. Florida Canyon Mine is applying cyanide to the heap at $13^{\circ} \mathrm{C}\left(55^{\circ} \mathrm{F}\right)$ and coming out of the heap at $16^{\circ} \mathrm{C}\left(60^{\circ} \mathrm{F}\right)$ even though the ambient air temperature is below freezing. Echo Bay Mines Round Mountain Mine is applying $71^{\circ} \mathrm{C}$ $\left(160^{\circ} \mathrm{F}\right)$ geothermal fluid through a heat exchanger to heat the cyanide solution, bringing the temperature from $6^{\circ} \mathrm{C}\left(42^{\circ} \mathrm{F}\right)$ to $21^{\circ} \mathrm{C}\left(70^{\circ} \mathrm{F}\right)$. The Director of the Division of Earth Sciences of the University, Dennis Trexler, believes that if the temperature could reach $24^{\circ} \mathrm{C}\left(75^{\circ} \mathrm{F}\right)$, gold recovery could be significantly enhanced for a given period of time.

The value of the natural heat in the heapleaching process, through which operators extract gold and silver from low-grade ore, is that the operation depends heavily on the weather, and active mines using the process either shut down during the winter or use expensive oil emersion heaters to prevent freezing. The University's lab studies showed that geothermal heat could enable operations to continue at a profitable level on a year-round basis and that metal recovery was from 17 percent to 40 percent greater.
The Earth Sciences Division research is continuing to determine the feasibility of using the geothermal fluids directly in the cyanide circuits, reducing the amount of fluids to be disposed of and eliminating the expense of injection. The unknown is whether the chemistry of geothermal fluids would be detrimental to ore recovery.

The initial studies were funded by the Department of Energy. The research continues under the auspices of the Bureau of Mines.

Source: Geothermal Report 2/1/88
On-site construction of the $\mathrm{CP}^{\text {. }}$ 12.5 MWe single flash geotherm Steamboat Springs, Nevada, 、 less Group er plant at npleted in 
four months. Orders of the main components were placed near the end of 1986, and delivery was made in the last quarter of 1987. The plant began commercial operation in February 1988. The power element is a General Electric marine engine of the Albany Class Cruiser obtained from the Geothermal Power Co. of Elmira, New York. The cost of the plant was about $\$ 15$ million.

Source: Geothermal Report 3/1/88

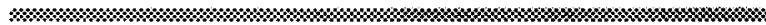
CALIFORNIA ENERGY COMPANY ANNOUNCES PLANS FOR DEVELOPMENT OF OREGON RESOURCES

California Energy Co. announced in May 1989 that it will move ahead with an exploration program to evaluate the potential for development of its geothermal energy resources in Oregon. It will open a district office in Portland and expand the permitting and environmental review processes required for further test drilling on its prospects located in central and southern Oregon.
"This is a first step in evaluating the commercial potential of the region's geothermal resources," Chairman Condy said. "It will involve a minimal and limited deployment of professional earth scientists at each prospect and will have little or no impact on the surrounding environment."

The company owns geothermal development rights on about 268,000 acres in Oregon, including sites at the Winema National Forest, the Bend Highlands, and the Santiam area. "With Northwest power planning experts predicting a significant increase in electricity demand by the mid-1990's, we believe the time to begin developing geothermal energy is now," Condy stated.

The company, he said, plans to spend between $\$ 20$ and $\$ 30$ million dollars on development of geothermal energy in the next five years to demonstrate the vast potential of geothermal energy to supply Oregon with a commercially viable and environmentally preferable source of electricity.

Condy concluded: "We have and will continue to work closely with the Northwest

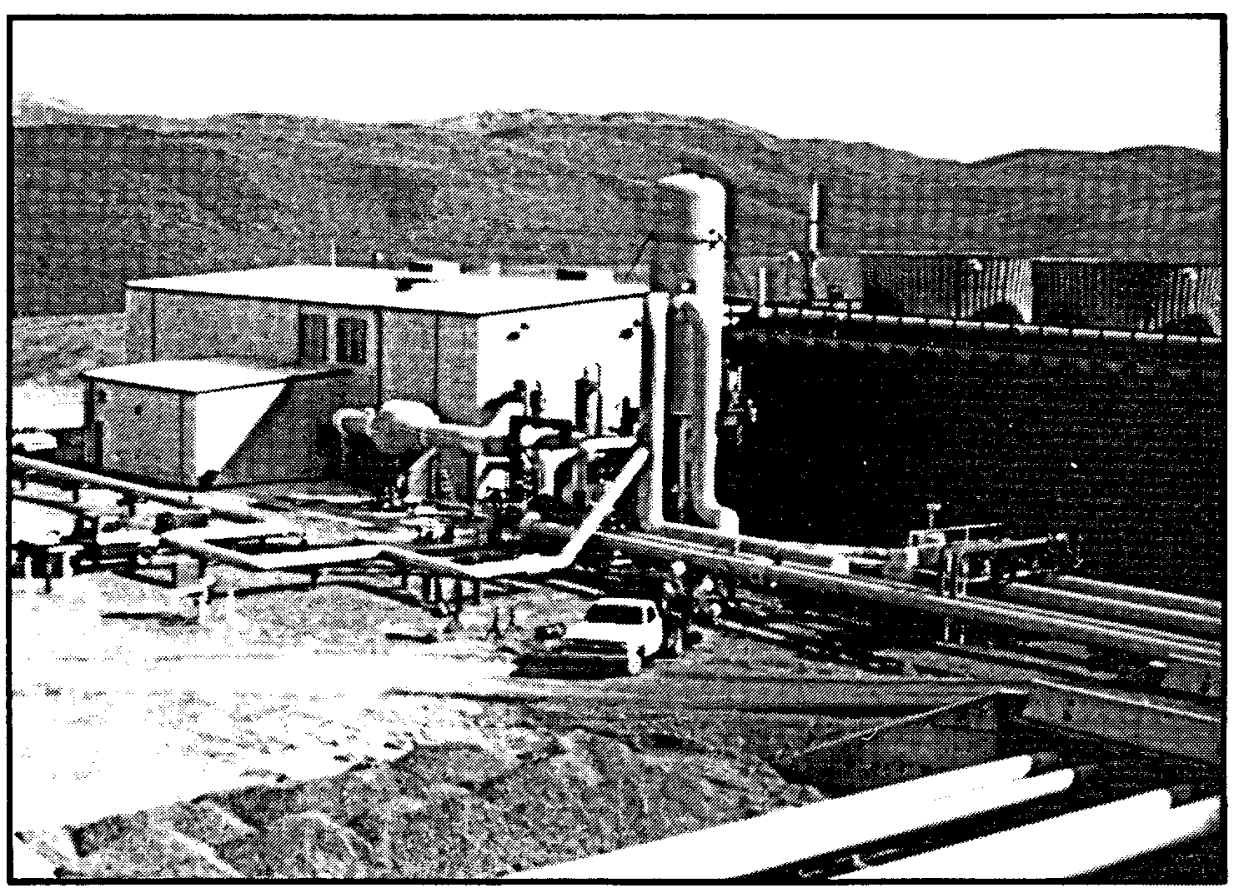

CAITHNESS PLANT AT STEAMBOAT SPRINGS 
Power Planning Council, the Bonneville Power Administration, local utilities and citizens. We will move forward with the greatest possible sensitivity to local and regional concerns. We intend to help the region gain a better understanding of this resource and, if appropriate, develop it for the benefit of the people of the Northwest."

\section{IID FACILITY IS PLACED IN SERVICE}

The Imperial Irrigation District's $\$ 54.3$ million, 104-mile, 230-KV transmission line to serve geothermal power plants in the Imperial Valley in California was placed in service from its Midway Substation near Niland to SCE's Coachella Substation near Indio in September 1988. The southern portion of the line from Highline, near the East Mesa KGRA, to Midway became operational in December 1988. A second connection with SCE was still needed to complete the big line's capacity.

Work began in the summer of 1987. The original plan was to start the line at Heber and to extend it up the center of the Valley, where IID already has a $161 \mathrm{KV}$ line that serves the Coachella Valley and connects with SCE at Indio. When geothermal development at Heber slowed down and development of East Mesa KGRA speeded up, the $230 \mathrm{KV}$ line was relocated along the west side of the East Highline Canal. A lesser feeder line will be built between Heber and the Highline Substation.

The line was financed by geothermal companies, who participated in proportion to the capacity they expect to utilize. All sell their power to SCE under Standard Offer No. 4 contracts. The IID considers the funds that were provided by the operators to be prepayment for future services. The District will operate and maintain the line and will, in effect, pay back the cost of the line through wheeling of power over a number of years. The 14 geothermal participants are: Chevron Geothermal Company of California; Del Ranch, Ltd.; Desert Power Company; Elmore, Ltd.; Earth Energy, Inc.; GEO East Mesa No. 2, Inc.; GEO East Mesa No. 3, Inc.; Heber Geothermal Company; Magma Power Company; Ormesa Geothermal; Ormesa Geothermal II; Union Oil Company of California; Vulcan/BN Geothermal Power Company; and Western Power
Group, Unit II, Inc. The line has a rated capacity of $600 \mathrm{MWe}$.

$\begin{array}{ll}\text { Sources: } & \text { Geothermal Resources Council } \\ & \text { Bulletin 12/88, 1/89 }\end{array}$

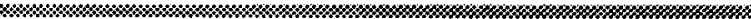
LARGE GEOTHERMAL GROWTH
RECORDED IN 1988-89; INDUSTRY
MATURING

As the following tables indicate, the geothermal industry has come a long way since its early beginnings. With the addition of over 300 MWe in total capacity in 1988 and 250 MWe in 1989 , the hot water industry is now represented by 33 plants totalling about $780 \mathrm{MWe}$. The Geysers has grown to 28 plants with a total capacity of nearly $2000 \mathrm{MWe}$.

While the industry has lost some members along the way, it has gained others, and, in its maturity, appears to have "settled in" for longterm development. Several significant circumstances, which the following tables illustrate, appear to have contributed substantially to the character of today's industry:

- the phenomenal success of some of its earliest entrepreneurs.

- Unocal's continued development and dominance of the industry in terms of total capacity.

- entry into the geothermal field of longtime members of other industrial communities.

- expansion of some companies from The Geysers to Imperial Valley and other areas.

An example of the first of these factors is the success of the California Energy Co. Since its formation in 1971 and first geothermal operations in 1975 in Central America, it has become the largest hot water field developer in the U.S.

Magma Power Co. is another major success story among the early entrepreneurs. Its interests go back to the 1950 s when it began to explore 
several areas in California and Nevada. Its current strong position in the industry rests on both its own early successes at The Geysers and in Imperial Valley and, according to company literature, increased holdings in the company by Dow Chemical which holds a number of key management positions.

With its purchase of the Magma East Mesa binary plant and two power sales contracts, GRI expanded its operations from The Geysers to Imperial Valley. Another very early entrant in the geothermal field, this company has been supplying the resource for nearly $60 \mathrm{MWe}$ at The Geysers since 1979 and more recently developed the steam for another $130 \mathrm{MWe}$ plant in the area. It has completed construction of a $37 \mathrm{MWe}$ plant at East Mesa in which Mission Energy has a half interest.

Mission is a relative newcomer to the field, although its parent, SCE, was a participant in the first two flash plants in the country, $10 \mathrm{MWe}$ demonstration units at the Brawley and Salton Sea in Imperial Valley. The utility ended its geothermal power generation activities with the sale of these units to Unocal.

A first for Unocal is the construction of its own 47.5 MWe plant at the Salton Sea. Except for assuming operation of the Salton Sea demonstration plant, the role of commercial producer of geothermal electricity is a new one for the Geothermal Division of the Company. In its other geothermal operations -- including production for 16 plants at The Geysers - the steam generated is delivered to power plants operated by other companies.

Chevron Resources Co., a subsidiary of the third largest oil company in the U.S. in terms of total assets, is also staying the course with geothermal energy. The company supplies the resource to a $47 \mathrm{MWe}$ plant at Heber, California, and a $20 \mathrm{MWe}$ plant in Utah; it operates both the field and plant at Desert Peak (9 MWe) and Beowawe (16 MWe), Nevada, the latter in partnership with Crescent Valley Energy Co., another SCE subsidiary.

Other important firms that have joined the geothermal industry during the 1980s include:

Ormat Energy Systems, Inc. - This company is a subsidiary of an Israeli energy firm specializing in modular organic Rankine cycle technology since 1965 . It now operates, for itself or in partnership with other companies, eight modular binary plants with a total capacity of over $80 \mathrm{MWe}$ in California and Nevada.

Oxbow Chemical - A subsidiary of a Boston-based energy company, Oxbow has completed a 50 MWe plant at Dixie Valley, Nevada, and a 220-mile transmission line to Bishop, California, the largest privately built and owned power line in the country. Its initial geothermal investment was over $\$ 100$ million.

Freeport-McMoRan, Inc. -- This New Orleans company and its subsidiaries are mineral producers (oil, gas, sulfur, uranium, gold, etc.) and, with its purchase of the geothermal interests of Phillips Petroleum, it became the second largest producer of geothermal energy in the U.S. It supplies steam for $318 \mathrm{MWe}$ at The Geysers and recently completed its own $20 \mathrm{MWe}$ plant in that area.

Small capacity developers include Pacific Energy, Trans-Pacific Geothermal/U.S. Energy Co., Wineagle, Honey Lake Power (a hybrid unit with largest output from waste wood), Caithness/Sequa, Tad's Enterprises, Utah Power \& Light, and Mother Earth/City of Provo. 


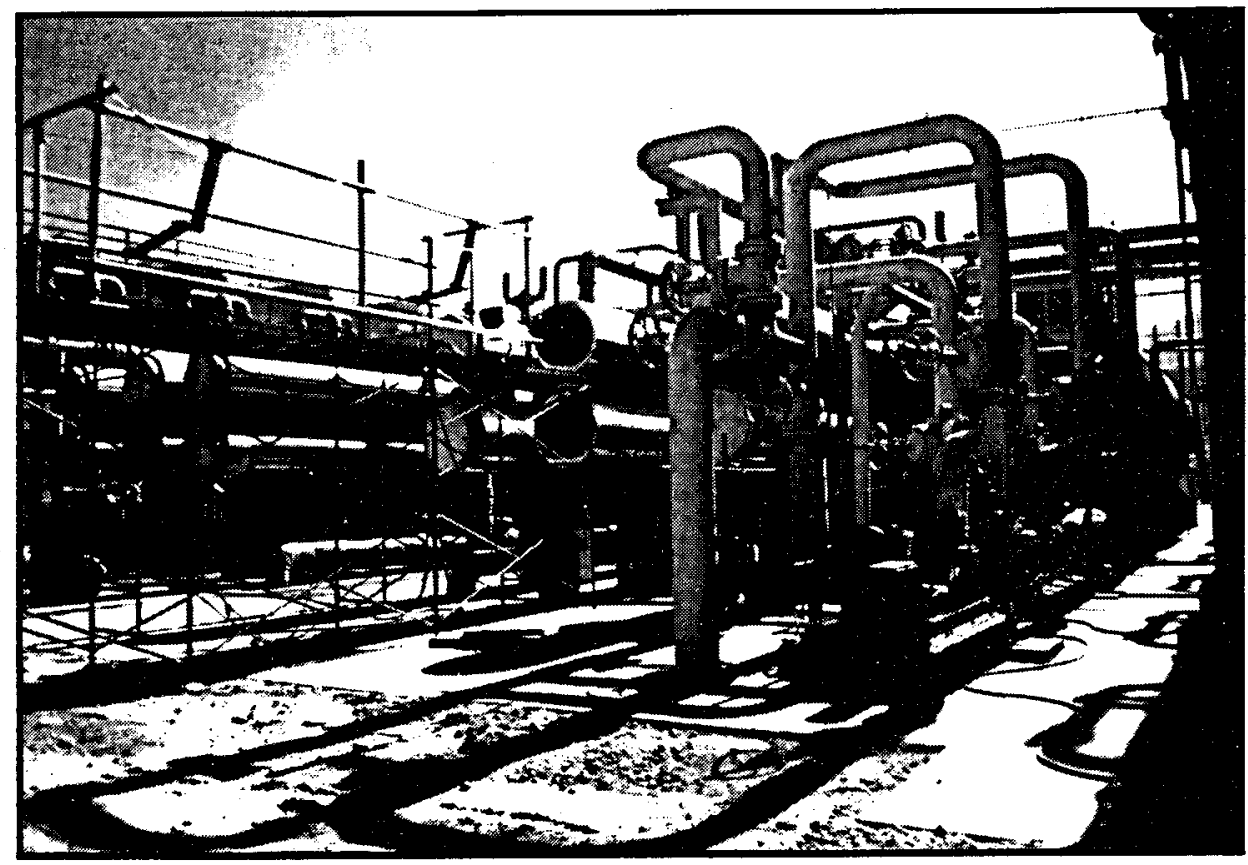

Neither geothermal power plant shown on this page uses wet cooling towers. The $7 \mathrm{MWe}$ Mammoth Geothermal Project shown above is the world's first modular air-cooled binary plant. It has been in operation since 1985 in the highly scenic area of Mammoth Lakes, California.

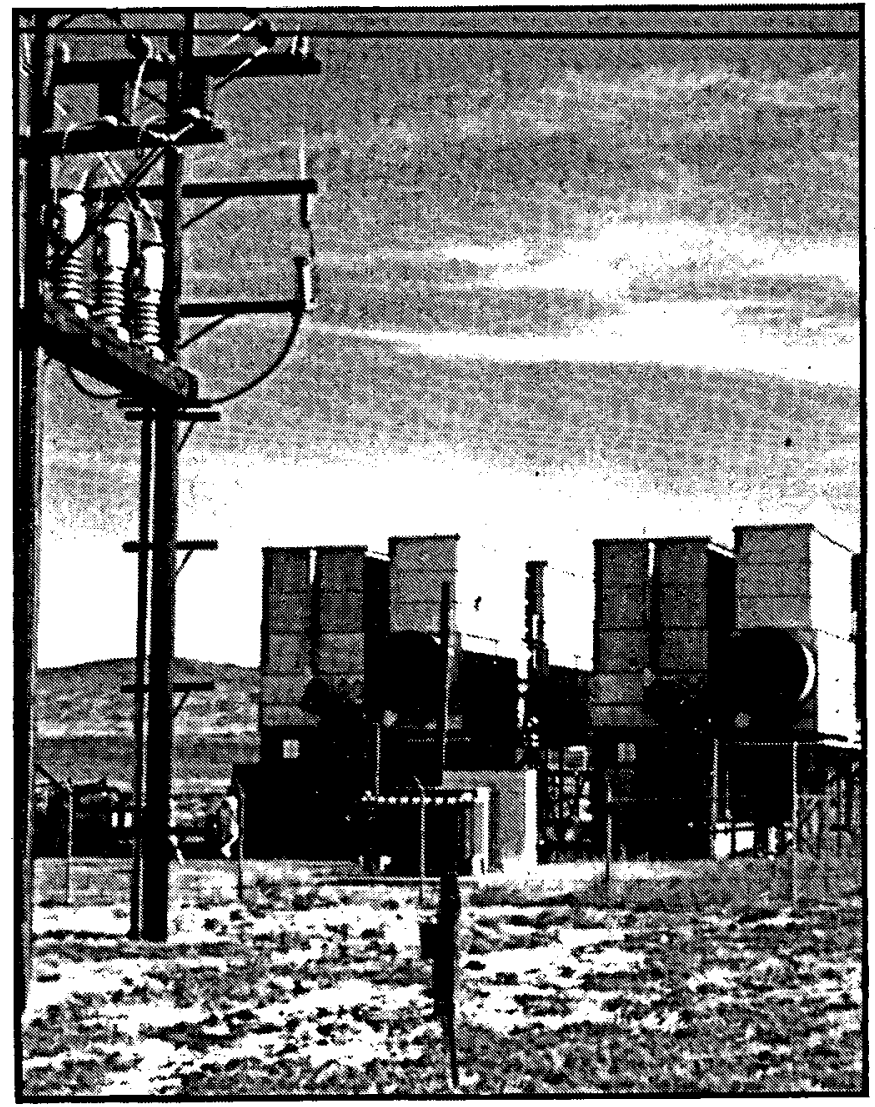

The key to the abbreviations used in the power plant tables is as follows:

\section{Plant Type}
DS - Dry Steam
DF - Dual Flash
SF - Single Flash
B - Binary

$\underline{\text { Utilities }}$

CCPA - Central California Power Agency

HELCO - Hawail Electric Light Co.

LADWP - Los Angeles Department of Water and Power

NCPA - Northern California Power Agency

PG\&E - Pacific Gas and Electric Co.

PP\&L - Pacific Power and Light Co.

SCE - Southern California Edison

SDG\&E - San Diego Gas and Electric Co.

SPP - Slerra Pacific Power Co.

UP\&L - Utah Power and Light Co.

The $600 \mathrm{kWe}$ Wineagle Power Project at Wendel, California, uses evaporative condensers for cooling. Its modular binary units were U.S.-made by Barber-Nichols. 
GEOTHERMAL ELECTRIC POWER PLANTS OPERATIONAL, UNDER CONSTRUCTION, AND PLANNED IN THE UNITED STATES

(Hot Water Plants)

\begin{tabular}{|c|c|c|c|c|c|c|c|}
\hline $\begin{array}{c}\text { LOCATION } \\
\text { (State and KGRA) }\end{array}$ & $\begin{array}{l}\text { PLANT } \\
\text { NAME }\end{array}$ & TYPE & $\begin{array}{c}\text { FIELD } \\
\text { DEVELOPER } \\
\end{array}$ & $\begin{array}{l}\text { PLANT } \\
\text { OWNER } \\
\end{array}$ & UTILITY & $\begin{array}{c}\text { RATED } \\
\text { CAPACITY } \\
\text { (MW) }\end{array}$ & $\begin{array}{c}\text { YEAR } \\
\text { ON LINE } \\
\end{array}$ \\
\hline \multicolumn{8}{|l|}{ CALIFORNIA } \\
\hline Brawley & & & SEE SALTON SEA & & & & \\
\hline \multirow[t]{5}{*}{ Coso Hot Springs } & $\begin{array}{l}\text { Navy Plant } \\
\text { No. } 1, \text { Units } \\
\text { No. } 1,2, \& 3\end{array}$ & DF & Calfornia Energy ${ }^{\bullet}$ & $\begin{array}{l}\text { Calliornla } \\
\text { Energy" }\end{array}$ & SCE & 80 & 1987-1988 \\
\hline & $\begin{array}{l}\text { 8LM East } \\
\text { (Units 1\&2) }\end{array}$ & DF & California Energy" & $\begin{array}{l}\text { Callfornla } \\
\text { Energy" }\end{array}$ & SCE & 48 & 1988 \\
\hline & BLM West & $\mathrm{DF}$ & California Energy" & $\begin{array}{l}\text { Calliornla } \\
\text { Energy" }\end{array}$ & SCE & 30 & 1989 \\
\hline & $\begin{array}{l}\text { Navy Plant } \\
\text { No. } 2, \text { Units } \\
\text { No. } 4,5, \& 6\end{array}$ & DF & California Energy" & $\begin{array}{l}\text { Calliornla } \\
\text { Energy" }\end{array}$ & SCE & 80 & 1989 \\
\hline & NA & DF & $\begin{array}{l}\text { Los Angeles Dept. } \\
\text { of Water and } \\
\text { Power (LADWP) }\end{array}$ & LADWP & LADWP & 20 & 1991 \\
\hline \multirow[t]{3}{*}{ East Mesa } & B.C. McCabe & B & $\begin{array}{l}\text { GEO Operator/ } \\
\text { Mission }\end{array}$ & GEO/Mission ${ }^{c}$ & SCE & $13.4^{\circ}$ & 1980 \\
\hline & Ormesa I & B & $\begin{array}{l}\text { Ormat Energy } \\
\text { Systems Inc. } \\
\text { (OESI) }\end{array}$ & OESI & SCE & 30 & 1987 \\
\hline & Ormesa II & B & $\begin{array}{l}\text { OESI/Harbert } \\
\text { International }\end{array}$ & OESI/Harbert & SCE & 20 & 1988 \\
\hline \multicolumn{8}{|c|}{$\begin{array}{l}\text { : Various venture partners are involved in all Callifornla Energy Coso plants } \\
\text { o Magma Power orlininal owner } \\
\text { c Mission Energy, a subsidiary of SCE } \\
\text { anlarged from } 10 \mathrm{MWe}\end{array}$} \\
\hline
\end{tabular}


GEOTHERMAL ELECTRIC POWER PLANTS OPERATIONAL, UNDER CONSTRUCTION, AND PLANNED

IN THE UNITED STATES

(Hot Water Plants)

\begin{tabular}{|c|c|c|c|c|c|c|c|}
\hline $\begin{array}{l}\text { LOCATION } \\
\text { (State and KGRA) }\end{array}$ & $\begin{array}{l}\text { PLANT } \\
\text { NAME }\end{array}$ & TYPE & $\begin{array}{c}\text { FIELD } \\
\text { DEVELOPER }\end{array}$ & $\begin{array}{l}\text { PLANT } \\
\text { OWNER }\end{array}$ & UTILITY & $\begin{array}{l}\text { RATED } \\
\text { CAPACITY } \\
\text { (MW) }\end{array}$ & $\begin{array}{l}\text { YEAR } \\
\text { ON LINE }\end{array}$ \\
\hline
\end{tabular}

CALIFOBNIA (Cont.)

\begin{tabular}{|c|c|c|c|c|c|c|}
\hline Ormesa IE & $\mathbf{B}$ & OESI & OESI & SCE & 9.5 & 1988 \\
\hline Ormesa lH & B & OESI & OESI/Harbert & SCE & 6 & NA \\
\hline GEM 1 & DF & GEO/Mission" & GEO/Mission" & SCE & 37 & 1989 \\
\hline NA & DF & GEO & GEO & SCE & 37 & NA \\
\hline $\begin{array}{l}\text { Heber Dual } \\
\text { Flash Power } \\
\text { Plant }\end{array}$ & DF & $\begin{array}{l}\text { Chevron } \\
\text { Resources Co. }\end{array}$ & $\begin{array}{l}\text { Calpine } \\
\text { Corp./ERC } \\
\text { International" }\end{array}$ & SCE & 47 & 1985 \\
\hline $\begin{array}{l}\text { Heber Binary } \\
\text { Project }^{c}\end{array}$ & B & Chevron & $\begin{array}{l}\text { Up for sale by } \\
\text { SDG\&E, IID, } \\
\text { and State of } \\
\text { Calif. }\end{array}$ & SDG\&E & 45 & 1985 \\
\hline $\begin{array}{l}\text { Mammoth } \\
\text { Paclfic (MP) } \\
\text { Unit I }\end{array}$ & B & Pacific Energy' & Pacific Energy & SCE & 7 & 1984 \\
\hline MP Unit II & B & Pacific Energy & Pacific Energy & SCE & 12 & NA \\
\hline MP Unit III & B & Pacific Energy & Pacific Energy & SCE & NA & NA \\
\hline
\end{tabular}

- Mission Energy, a subsidlary of SEC

b Partnership of Dravo Corp. and Centennial Energy original owner

- Demonstration plant supported by the U.S. Dept. of Energy; currently not in operation

- Subsidiary of Pacific Enterprises 


\begin{tabular}{|c|c|c|c|c|c|c|c|}
\hline \multirow[b]{2}{*}{$\begin{array}{l}\text { LOCATION } \\
\text { (State and KGRA) } \\
\end{array}$} & \multirow[b]{2}{*}{$\begin{array}{l}\text { PLANT } \\
\text { NAME }\end{array}$} & \multirow[b]{2}{*}{ TYPE } & \multirow[b]{2}{*}{$\begin{array}{l}\text { FIELD } \\
\text { DEVELOPER }\end{array}$} & \multirow[b]{2}{*}{$\begin{array}{l}\text { PLANT } \\
\text { OWNER }\end{array}$} & \multirow[b]{2}{*}{ UTILITY } & \multirow[b]{2}{*}{$\begin{array}{c}\text { RATED } \\
\text { CAPACITY } \\
\text { (MW) }\end{array}$} & \multirow[b]{2}{*}{$\begin{array}{l}\text { YEAR } \\
\text { ON LINE }\end{array}$} \\
\hline & & & & & & & \\
\hline \multicolumn{8}{|l|}{ CALIFORNIA (Com.) } \\
\hline & $\begin{array}{l}\text { Pacific } \\
\text { Lighting } \\
\text { Energy } \\
\text { Systems } \\
\text { (PLES) Unit I }\end{array}$ & B & PLES & PLES & SCE & 10 & NA \\
\hline & $\begin{array}{l}\text { Mammoth- } \\
\text { Chance B } \\
\text { Development } \\
\text { Project }\end{array}$ & B & $\begin{array}{l}\text { Bonneville Pacific } \\
\text { Corp. }\end{array}$ & Bonneville & SCE & 10 & NA \\
\hline \multirow[t]{6}{*}{ Salton Sea } & $\begin{array}{l}\text { Salton Sea } \\
\text { Unit } 1\end{array}$ & SF & $\begin{array}{l}\text { Earth Energy" } \\
\text { (acquired full field } \\
\text { ownership from } \\
\text { partners Southern } \\
\text { Pacific Land Co. } \\
\text { and Mono Power) }\end{array}$ & Earth Energy & SCE & $10^{\mathrm{c}}$ & 1982 \\
\hline & Unit 2 & & Earth Energy" & Earth Energy" & SCE & $15^{\mathrm{c}}$ & 1990 \\
\hline & Vulcan & & Magma/Mission & $\begin{array}{l}\text { Magma/ } \\
\text { Mission }\end{array}$ & SCE & 34 & 1986 \\
\hline & Del Ranch & DF & Magma/Mission ${ }^{d}$ & $\begin{array}{l}\text { Magma/ } \\
\text { Mlssion }\end{array}$ & SCE & 34 & 1988 \\
\hline & Elmore I & DF & Magma/Misslon ${ }^{\circ}$ & $\begin{array}{l}\text { Magma// } \\
\text { Mission }\end{array}$ & SCE & 34 & 1988 \\
\hline & Leathers 1 & $\mathrm{DF}$ & Magma/Mission ${ }^{d}$ & $\begin{array}{l}\text { Magma/ } \\
\text { Mission }\end{array}$ & SCE & 34 & 1989 \\
\hline $\begin{array}{l}\text { Unocal subsidiary } \\
\text { : SCE original owner }\end{array}$ & & \multicolumn{6}{|c|}{$\begin{array}{l}\text { ¿ Will include } 10 \mathrm{MWe} \text { SCE demonstration plant prevlously dismantled at Brawley } \\
\text { d Mission Energy Co., a subsidiary of SCE }\end{array}$} \\
\hline
\end{tabular}


GEOTHERMAL ELECTRIC POWER PLANTS OPERATIONAL, UNDER CONSTRUCTION, AND PLANNED

IN THE UNITED STATES

(Hot Water Plants)

\begin{tabular}{|c|c|c|c|c|c|c|c|}
\hline $\begin{array}{c}\text { LOCATION } \\
\text { (State and KGRA) }\end{array}$ & $\begin{array}{l}\text { PLANT } \\
\text { NAME }\end{array}$ & TYPE & $\begin{array}{c}\text { FIELD } \\
\text { DEVELOPER } \\
\end{array}$ & $\begin{array}{l}\text { PLANT } \\
\text { OWNER } \\
\end{array}$ & UTILTY & $\begin{array}{c}\text { RATED } \\
\text { CAPACITY } \\
\text { (MW) }\end{array}$ & $\begin{array}{c}\text { YEAR } \\
\text { ON LINE } \\
\end{array}$ \\
\hline \multicolumn{8}{|l|}{ CALLORNIA (Com) } \\
\hline & $\begin{array}{l}\text { Satton Sea } \\
\text { Untt } 3\end{array}$ & DF & Desert Powere & Desert Power" & SCE & 47.5 & 1989 \\
\hline \multirow[t]{3}{*}{ Wendel-Amedee } & $\begin{array}{l}\text { Wineagle } \\
\text { Project }\end{array}$ & B & $\begin{array}{l}\text { Wineagle } \\
\text { Developer }\end{array}$ & $\begin{array}{l}\text { Wineagle } \\
\text { Developer }\end{array}$ & PG\&E & 7 & 1987 \\
\hline & $\begin{array}{l}\text { Amedee } \\
\text { Geothermal }\end{array}$ & B & $\begin{array}{l}\text { Trans-Pacific } \\
\text { Geothermal Inc. } \\
\text { (TPG)/U.S. Energy } \\
\text { Corp. }\end{array}$ & TPG/U.S. & PG\&E & $2^{c}$ & 1988 \\
\hline & $\begin{array}{l}\text { Honey Lake } \\
\text { Power Facilty }\end{array}$ & $B^{d}$ & GeoProducts Corp. & HL Power Co: & PG\&E & $30^{\circ}$ & 1989 \\
\hline \multicolumn{8}{|l|}{ HAWAII } \\
\hline Puna' & HGP-A & SF & Barmwell Industries & HELCO & HELCO & 3 & 1981 \\
\hline \multicolumn{8}{|c|}{ 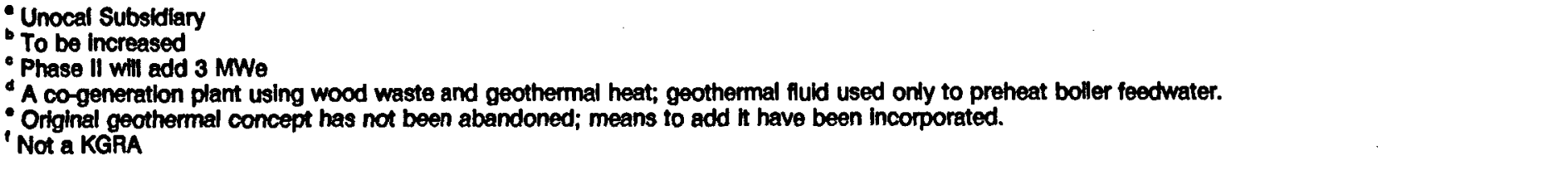 } \\
\hline
\end{tabular}




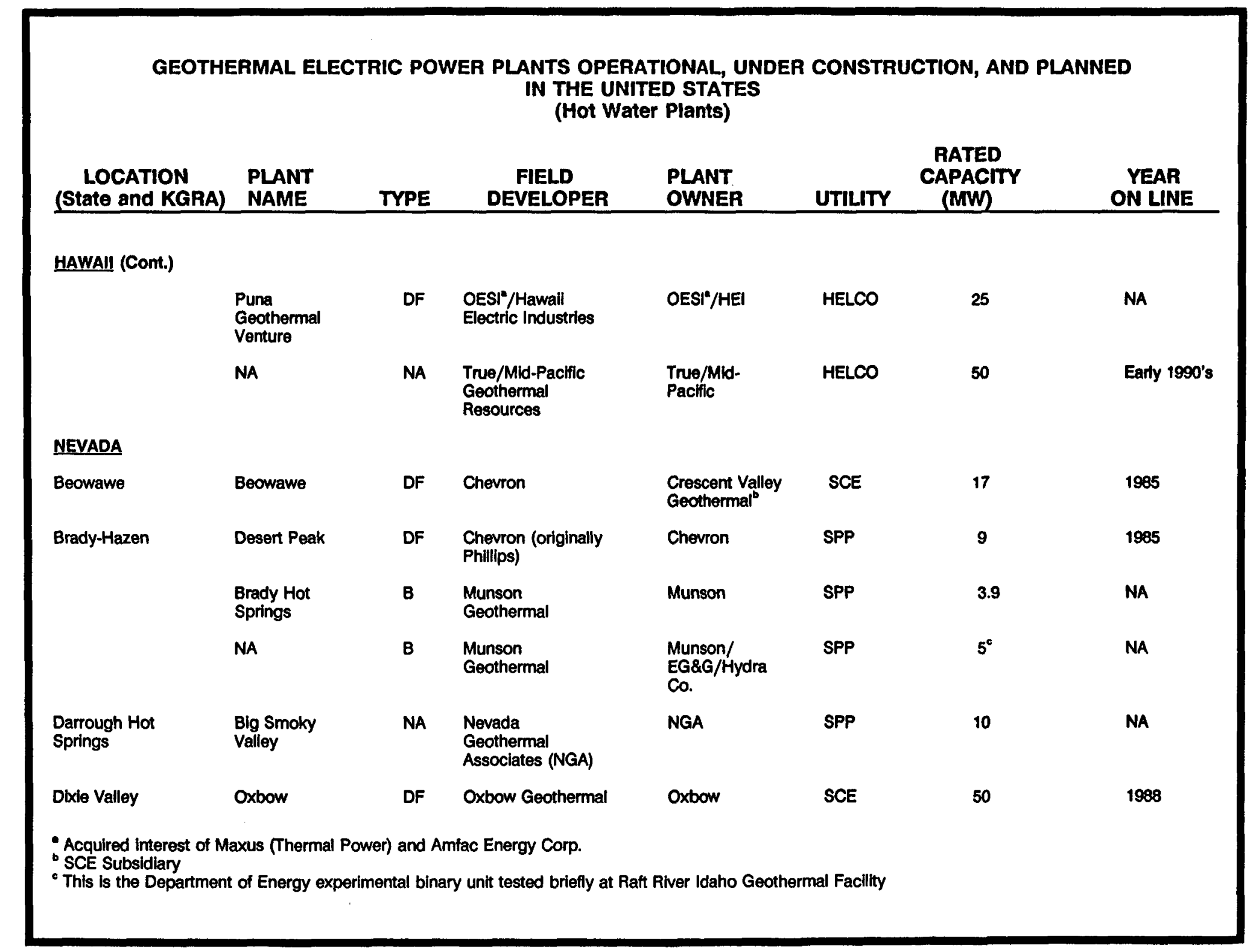




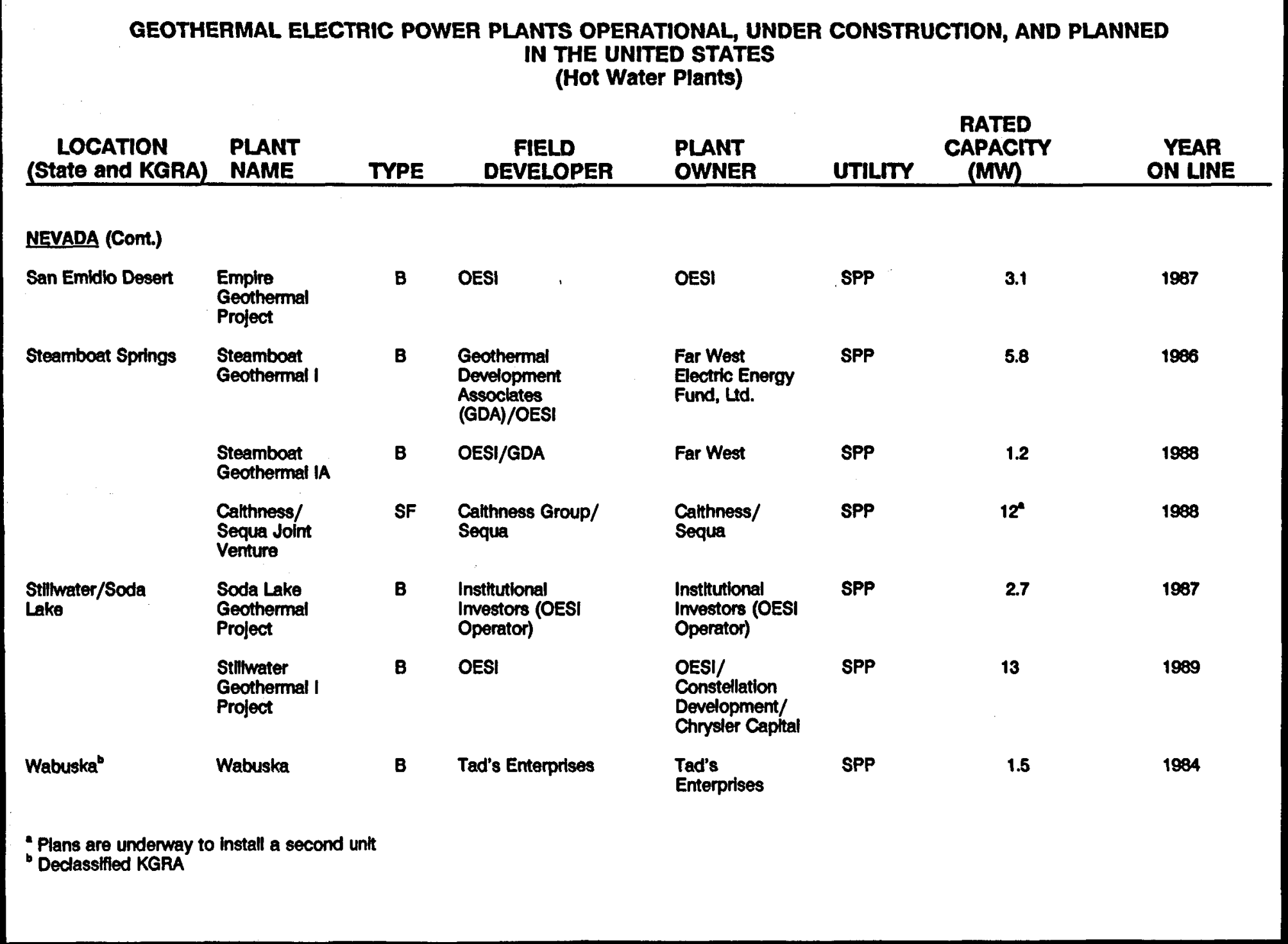


GEOTHERMAL ELECTRIC POWER PLANTS OPERATIONAL, UNDER CONSTRUCTION, AND PLANNED IN THE UNITED STATES

(Hot Water Plants)

\begin{tabular}{|c|c|c|c|c|c|c|c|}
\hline $\begin{array}{c}\text { LOCATION } \\
\text { (State and KGRA) }\end{array}$ & $\begin{array}{l}\text { PLANT } \\
\text { NAME } \\
\end{array}$ & TYPE & $\begin{array}{c}\text { FIELD } \\
\text { DEVELOPER }\end{array}$ & $\begin{array}{l}\text { PLANT } \\
\text { OWNER }\end{array}$ & UTILITY & $\begin{array}{l}\text { RATED } \\
\text { CAPACITY } \\
\text { (MW) }\end{array}$ & $\begin{array}{r}\text { YEAR } \\
\text { ON LINE } \\
\end{array}$ \\
\hline \multicolumn{8}{|l|}{ NEW MEXICQ } \\
\hline Lighting Dock & $\begin{array}{l}\text { Burgett Floral, } \\
\text { Inc. }\end{array}$ & B & NA & Burgett Floral & $\cdot$ & $<1$ & 1984 \\
\hline Glla Hot Springs & & B & NA & NA & $\begin{array}{l}\text { Power will be } \\
\text { distributed to } \\
\text { small } \\
\text { community }\end{array}$ & (10kW) & NA \\
\hline \multicolumn{8}{|l|}{ UTAH } \\
\hline $\begin{array}{l}\text { Roosevelt Hot } \\
\text { Springs }\end{array}$ & Blundell I & SF & $\begin{array}{l}\text { Chovron (originally } \\
\text { Phillips) }\end{array}$ & $\begin{array}{l}\text { Utah Power Dlv. } \\
\text { (UPD) of } \\
\text { Pacificorp. }\end{array}$ & UPD & 20 & 1984 \\
\hline \multirow[t]{2}{*}{$\begin{array}{l}\text { Cove Fort- } \\
\text { Sulphurdale }\end{array}$} & $\begin{array}{l}\text { Cove Fort } \\
\text { Geothermal } \\
\text { No. } 1\end{array}$ & B & Mother Earth & Clty of Provo & $\begin{array}{l}\text { Utah } \\
\text { Municipal } \\
\text { Power } \\
\text { Agency }\end{array}$ & $3.8^{\mathrm{b}}$ & 1985 \\
\hline & $\begin{array}{l}\text { Cove Fort } \\
\text { Steam Plant }\end{array}$ & SF & Mother Eanth & Clity of Provo & $\begin{array}{l}\text { Provo Power } \\
\text { Co. }\end{array}$ & 2 & 1988 \\
\hline
\end{tabular}

- Power used for greenhouse needs

- 7.5 MWe addition under construction 

GEOTHERMAL ELECTRIC POWER PLANTS OPERATIONAL, UNDER CONSTRUCTON, AND PLANNED
IN THE UNTED STATES

(Dry Steam Plants at The Geysers)

\begin{tabular}{|c|c|c|c|c|c|}
\hline \multirow[b]{2}{*}{$\begin{array}{l}\text { PLANT } \\
\text { NAME }\end{array}$} & \multirow[b]{2}{*}{$\begin{array}{l}\text { FEELD } \\
\text { DEVELOPER } \\
\end{array}$} & \multirow[b]{2}{*}{$\begin{array}{l}\text { PLANT } \\
\text { OWNER } \\
\end{array}$} & \multirow[b]{2}{*}{ umerr } & \multirow{2}{*}{$\begin{array}{r}\text { RATED } \\
\text { CAPACTY } \\
\text { (MW } \\
\end{array}$} & \multirow[b]{2}{*}{$\begin{array}{r}\text { YEAR } \\
\text { ON LNE } \\
\end{array}$} \\
\hline & & & & & \\
\hline PG\&E Untt No. 1 & UNOCAL/Magma/Thermal & PG\&E & PG\&E & 11 & 1960 \\
\hline No. 2 & " & $\bullet$ & " & 18 & 1963 \\
\hline No. 3 & - & " & • & 27 & 1967 \\
\hline No. 4 & - & • & • & 27 & 1968 \\
\hline No. 5 & " & " & $\bullet$ & 53 & 1971 \\
\hline No. 6 & • & " & " & 53 & 1971 \\
\hline No. 7 & " & $"$ & $"$ & 53 & 1972 \\
\hline No. 8 & - & " & " & 53 & 1972 \\
\hline No. 9 & - & " & $"$ & 53 & 1973 \\
\hline No. 10 & $"$ & " & " & 53 & 1973 \\
\hline No. 11 & • & " & " & 106 & 1975 \\
\hline No. 12 & • & $\cdot$ & " & 106 & 1976 \\
\hline No. 15 & $\begin{array}{l}\text { GEO Operator Corp. } \\
\text { (orlginally Thermogenlcs) }\end{array}$ & • & • & 59 & 1979 \\
\hline No. 13 & $\begin{array}{l}\text { Freeport-McMoRan } \\
\text { (originally Aminoll) }\end{array}$ & " & " & 133 & 1980 \\
\hline No. 14 & $\begin{array}{l}\text { UNOCAL/Magma/Thermal } \\
\text { (Natomas) }\end{array}$ & " & " & 109 & 1980 \\
\hline
\end{tabular}




\section{GeOtHeRMAL ELECTRIC POWER PLANTS OPERATIONAL, UNDER CONSTRUCTION, AND PLANNED IN THE UNITED STATES}

(Dry Steam Plants at The Geysers)

\begin{tabular}{|c|c|c|c|c|c|}
\hline $\begin{array}{l}\text { PLANT } \\
\text { NAME } \\
\end{array}$ & $\begin{array}{c}\text { FIELD } \\
\text { DEVELOPER }\end{array}$ & $\begin{array}{l}\text { PLANT } \\
\text { OWNER }\end{array}$ & UTITY & $\begin{array}{l}\text { RATED } \\
\text { CAPACTY } \\
\text { (MW) }\end{array}$ & $\begin{array}{c}\text { YEAR } \\
\text { ON LNE }\end{array}$ \\
\hline No. 17 & $\begin{array}{l}\text { UNOCAL/Magma/Thermal } \\
\text { (Natomas) }\end{array}$ & PG\&E & PG\&E & 110 & 1982 \\
\hline No. 18 & $\begin{array}{l}\text { UNOCAL/Magma/Thermal } \\
\text { (Natomas) }\end{array}$ & PG\&E & PG\&E & 110 & 1983 \\
\hline SMUDGEO NO. 1 & $\begin{array}{l}\text { Freeport - McMoRan (originally } \\
\text { Aminoil) }\end{array}$ & $\begin{array}{l}\text { Sacramento } \\
\text { Municipal Utillty } \\
\text { District }\end{array}$ & SMUD & 65 & 1983 \\
\hline NCPA No. $1^{a}$ & $\begin{array}{l}\text { Northern Calif. Power Agency } \\
\text { (originally Grace Geothermal) }\end{array}$ & NCPA & NCPA & 110 & 1983 \\
\hline Oxy Geothermal 1 & $\begin{array}{l}\text { Santa Fe Geothermal (originally } \\
\text { Occidental) }\end{array}$ & $\begin{array}{l}\text { Samta } \mathrm{Fe} \\
\text { Geothermal }\end{array}$ & PG\&E & 80 & 1984 \\
\hline Bottle Rock & $\begin{array}{l}\text { Calfornia Dept. of Water } \\
\text { Resources }\end{array}$ & $\begin{array}{l}\text { Calif. Dept of } \\
\text { Water Resources }\end{array}$ & $\begin{array}{l}\text { Calf. Dept of } \\
\text { Water } \\
\text { Resources }\end{array}$ & 55 & 1985 \\
\hline NCPA No. 2" & NCPA & NCPA & NCPA & 110 & 1985 \\
\hline PG\&E Unit No. 16 & $\begin{array}{l}\text { Freeport - McMoRan (originally } \\
\text { Aminoil) }\end{array}$ & PG\&E & PG\&E & 110 & 1985 \\
\hline No. 20 & $\begin{array}{l}\text { UNOCAL/Thermal (Diamond } \\
\text { Shamrock) }\end{array}$ & PG\&E & PG\&E & 110 & 1985 \\
\hline
\end{tabular}

- Originally NCPA No. 2 and 3

- Purchased from MCR Geothermal, Entex Petroleum, and Geothermal Kinetics, Inc. 
GEOTHERMAL ELECTRIC POWER PLANTS OPERATIONAL, UNDER CONSTRUCTION, AND PLANNED

IN THE UNTIED STATES

(Dry Steam Plants at The Geysers)

\begin{tabular}{|c|c|c|c|c|c|}
\hline $\begin{array}{l}\text { PLANT } \\
\text { NAME } \\
\end{array}$ & $\begin{array}{c}\text { FIELD } \\
\text { DEVELOPER }\end{array}$ & $\begin{array}{l}\text { PLANT } \\
\text { OWNER }\end{array}$ & vmurr & $\begin{array}{c}\text { RATED } \\
\text { CAPACIY } \\
\text { (MW) }\end{array}$ & $\begin{array}{c}\text { YEAR } \\
\text { ON LNE }\end{array}$ \\
\hline Cold Water Creek & $\begin{array}{l}\text { Geothermal Resources } \\
\text { International }\end{array}$ & $\mathrm{CCPA}^{\circ}$ & CCPA" & 130 & 1988 \\
\hline Bear Canyon Creek & $\begin{array}{l}\text { Freeport - McMoRan (Geysers } \\
\text { Geothermal) }\end{array}$ & $\begin{array}{l}\text { Freepont - } \\
\text { MoMoRan } \\
\text { (Geysers } \\
\text { Geothermal) }\end{array}$ & PG\&E & 22 & 1988 \\
\hline West Fond Flat & $\begin{array}{l}\text { Freeport - McMoRan (Geysers } \\
\text { Geothermal) }\end{array}$ & $\begin{array}{l}\text { Freeport - } \\
\text { McMoRan } \\
\text { (Geysers } \\
\text { Geothermal) }\end{array}$ & PG\&E & 27 & 1988 \\
\hline $\begin{array}{l}\text { Joseph W. Aldin } \\
\text { Power Plant }\end{array}$ & Geothermal Energy Partners ${ }^{b}$ & $\begin{array}{l}\text { Geothermal } \\
\text { Energy Partners/ } \\
\text { Cloverdale } \\
\text { Geothermal } \\
\text { Partners }^{\circ}\end{array}$ & PG\&E & 20 & 1989 \\
\hline
\end{tabular}

- Plant ownership divided among Sacramento Municipal Utility District (SMUD), Modesto Irrigation District (MID), and the City of Santa Clara.

- A subsidiary of Mission Power is general partner.

- Calpline Corp. and Metlife Capttal Corp. (affillate of Metropolitan Life Ins. Co.) 


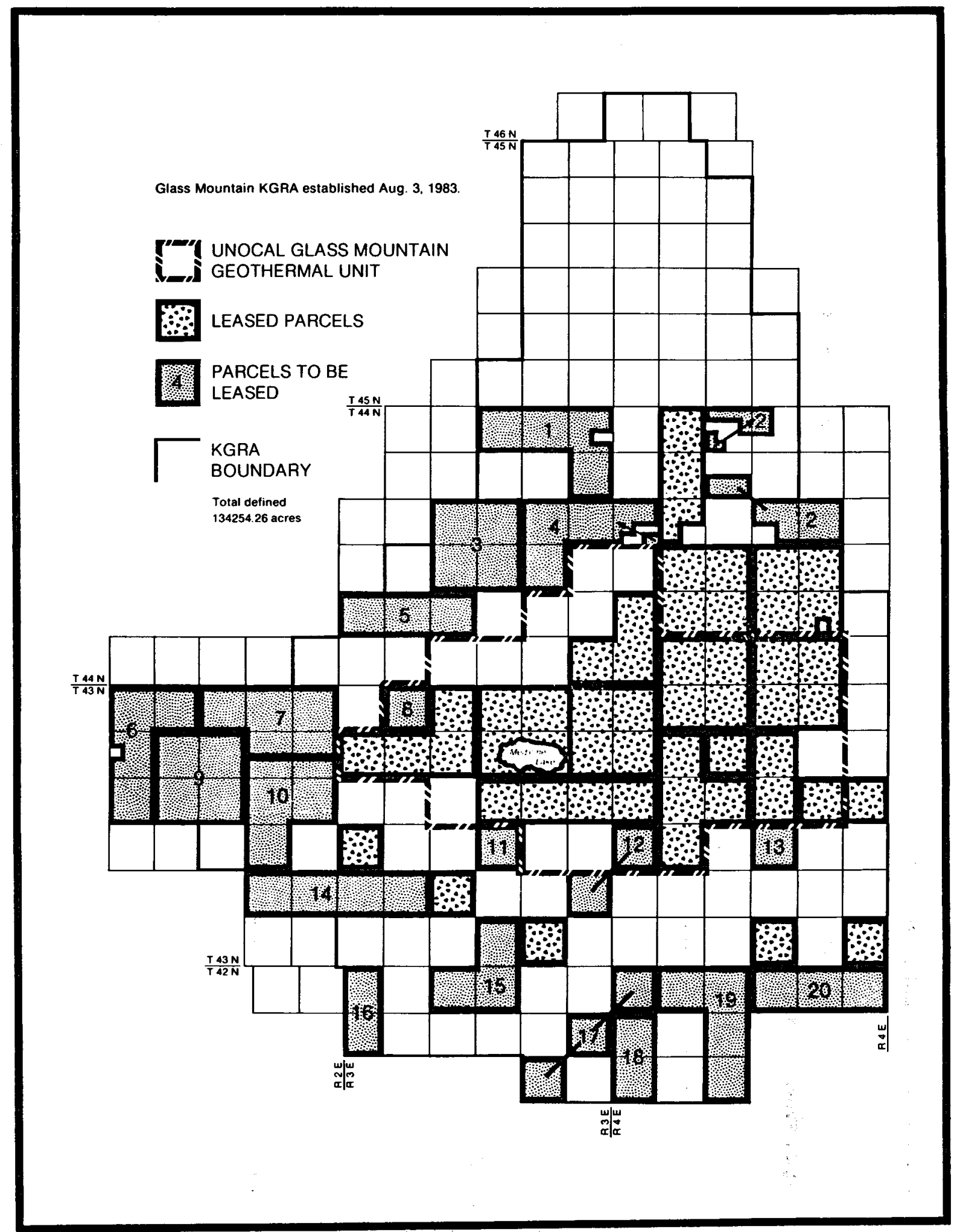

GLASS MOUNTAIN KGRA

IN NORTHERN CALFORNIA

(See Page 44 for details of lease sale.) 
GEOTHERMAL LEASE EXTENSION LEGISLATION ENACTED; STATUTE ALSO EXTENDS IMPACT OF THERMALFEATURES RESTRICTIONS

Legislation to remove the restrictions on extensions of federal geothermal leases at the end of the 10-year primary term was signed into law on September 22, 1988. Long sought by the geothermal industry, the statute (P.L. 100-443) recognizes today's economic realities in using or selling the resource.

The bill also extends the impact of the thermal features in national parks restrictions (P.L. 99591) enacted in 1986. To further protect Yellowstone National Park, the bill prohibits any geothermal development in the Corwin Springs Known Geothermal Resources Area (KGRA) in Montana until the U.S. Geological Survey completes its study of the potential impact of development on the park's thermal features.

The bill also adds Crater Lake National Park in Oregon to the previously promulgated list of significant thermal features. A study of Crater Lake, already under way by the Interior Department to determine the presence or absence of thermal vents, was mandated by the bill to be completed in March 1989. As of this writing, the study is not yet finished.

The Geothermal Steam Act of 1970 (P.L. 91581), as it was enacted, required that for a lease to qualify for an extension, geothermal "steam" must be "produced or utilized in commercial quantities." Production or utilization in commercial quantities was defined to include the completion of one or more wells producing or capable : of producing geothermal steam in commercial quantities and a bona fide sale of such geothermal steam.

Under the new legislation, leases may be extended for up to two successive five-year periods if:

- the lessee has submitted a report to the Secretary of the Interior detailing bona fide efforts to produce or utilize geothermal steam in commercial quantities for such lease, given the then -current economic conditions, and either

- the lessee, to substitute payments in lieu of royalties on production, agrees to modification of the terms of his lease to pay:

- $\quad$ At least $\$ 3 /$ acre for each of the first five years for the acreage in the lease

- At least $\$ 6 /$ acre from the 6 th through the 10th year; or

- the lessee demonstrates on an annual basis during an extension that a significant expenditure of funds is being made on the lease.

Expenditures may include drilling on the lease for exploratory or development wells, geophysical or geochemical surveys, construction of roads or generating facilities, architectural or engineering services for design of generating facilities, and environmental studies. To qualify, the expenditures must total at least $\$ 15 /$ acre for each of the first five years and at least $\$ 18$ /acre for the 6th through the 10th years for lands under the lease.

The term "produced or utilized in commercial quantities" is redefined to include 1) the completion of a well producing geothermal steam in commercial quantities, or 2) completion of a well capable of producing geothermal steam in commercial quantities so long. as the Secretary determines that diligent efforts are being made toward the utilization of geothermal steam.

Leases extended under the provisions of P.L. 100-443 or pursuant to subsection (c) of Section 6 of the Steam Act may continue in force for up to a total of $\mathbf{5 0}$ years if "geothermal steam is produced or utilized in commercial quantities."

Other provisions of P.L. $100-443$ include:

- A mandated review of cooperative or unit plans within five years of their approval, and every five years thereafter, to eliminate leases or parts of leases not regarded as necessary to cooperative or unit operations. 
- Insertion of the language of the significant thermal features legislation into the Geothermal Steam Act. Interim rules for implementing the Act were published in the Federal Register of April 6,1989 . No date has been set as of this writing for publication of the final regulations.

The exclusion of the Corwin Springs KGRA from immediate development was prompted by concern over a well drilled on private property for a direct use application nine miles from the nearest thermal feature in the park. Except that this action indicates the broad power that could derive from the authority of the thermal features legislation to hinder development, the action itself will probably have no effect on the industry. The estimated fluid temperatures in the KGRA are unsuitable for power generation. The addition of Crater Lake National Park to the list of significant thermal features could affect the course of the exploration program of California Energy, which is test drilling in the area, and other developers in the future.

\section{GLASS MOUNTAIN LEASE SALE DRAWS ACTIVE BIDDING}

On April 6, 1988, the Bureau of Land Management opened bids for the Glass Mountain KGRA in northern California. This lease sale is significant in that up to four companies submitted bids for three of the parcels, and three companies submitted bids on seven other parcels. This is the first lease sale with this amount of competition in several years. It may be a forerunner of an expected increase in geothermal exploration activity in the western U.S.

Freeport McMoRan Resource Partners (FMRP) came away with most of the parcels, bidding $\$ 3,000,125$ for seven parcels totalling 12,023 acres. FMRP bid more than its competitors on all parcels, often by an order of magnitude. Unocal competed for six of the FMRP parcels, coming in second each time. Still further behind was California Energy Co., which bid on four parcels, coming in a distant third, three times to Unocal and once to Ormat Systems, Inc. (OSI). Ormat fared better on its other bids, offering
$\$ 54,562$ for four parcels totaling 10,255 acres. OSI was the sole bidder in all four cases.

When the bidding was completed, BLM had received 29 bids on 20 parcels, totaling 38,284 acres. Of the 20 parcels, 12 were bid on, bringing in a total of $\$ 3,056,383$. Total money exposed was $\$ 3,561,951$. The average of per acre high bids was $\$ 232.11$, with $\$ 114.02$ the average bid.

Source: Geothermal Resources Council Bulletin 6/88.

\section{SOME SURPRISES AT BLM'S EAST MESA BID OPENING}

When the bids were opened by the Bureau of Land Management in Sacramento on June 7, 1989 for three parcels in Imperial Valley's East Mesa KGRA, there were some surprises. Here are the results:

- $\quad$ Parcel 1: 1,595.19 acres at the north of the KGRA near the Ormesa Geo 1 Plant. Two bidders: Magma Power Company, San Diego, \$16,001.50 (high bid); Ormat Energy Systems, Inc., Sparks, NV, $\$ 3,689.07$ (low bid).

- Parcel 2: 80 acres at the East Highline Canal west of the McCabe Plant. Three bidders: Ormat, $\$ 13,028.80$ (high bid); Magma, $\$ 5,001.50$ (second high); and Geothermal Resources International of San Mateo, through its GRI Exploration Corp., $\$ 1,335.20$ (low bid).

- $\quad$ Parcel 3: 430 acres at the southeast of the KGRA. No bids.

GRI, which had petitioned BLM to advertise the units, was expected to be more competitive for Parcel 2, which would fit well with the development of its second plant in the vicinity. Ormat was expected to put up a tougher fight for Parcel 1. Magma, though the most experienced in the East Mesa, had shifted its attention to Niland after selling the McCabe Plant to GRI, though Magma is still the leaseholder of record on lands in the vicinity of Parcel 2.

Source: Geothermal Report 6/15/89 


\section{STATUS OF FEDERAL LEASING PROGRAM}

Geothermal energy development on federal lands produced 795 MWe of power in 1988, the equivalent of 945,000 barrels of oil per month, or enough to supply the power needs of almost 800,000 people. This alternative energy source also earned $\$ 13.96$ million in rents and royalties for the federal, state, and county treasuries from 268 federal leases covering 414,230 acres.

California is already the world leader in geothermal energy production, and activity on federal lands in 1988 continued to expand.

The largest producer is The Geysers in northeastern Sonoma County, which employs 2,000 local residents and pays a $\$ 48$ million annual payroll. Sixteen new wells were drilled in 1988 on the 12 federal leases, bringing the total federal wells to 158 . These wells produced 725 MWe of power.

At East Mesa in Imperial County, two 37MWe and one 10-MWe plants were approved in 1988, joining the 70-MWe facilities already producing. Additional plans for another 20-MWe plant were submitted. When all these plants are on-line, enough geothermal energy will be produced to supply power to almost 175,000 people.

One hundred megawatts of the development at Coso lie on royalty-producing federal leases and will generate up to 30 percent of Inyo County's annual income.

\section{GEOTHERMAL LEASING AND OPERATIONS}

\begin{tabular}{|c|c|c|c|}
\hline \multirow[b]{2}{*}{ Total Number of Leases } & \multicolumn{3}{|c|}{$\underline{1986} 1987 \underline{1988}$} \\
\hline & 365 & 293 & 268 \\
\hline Competitive Leases Issued & 2 & $0^{*}$ & 12 \\
\hline $\begin{array}{l}\text { Noncompetitive Leases } \\
\text { Issued }\end{array}$ & 39 & $\mathbf{0}$ & 0 \\
\hline $\begin{array}{l}\text { Federal Production } \\
\text { (megawatts) }\end{array}$ & 735 & 754 & 795 \\
\hline Producing Leases & 14 & 15 & 16 \\
\hline $\begin{array}{l}\text { Producing Wells } \\
\text { Plans of Operation }\end{array}$ & 132 & 167 & 186 \\
\hline Approved & 11 & 14 & 93 \\
\hline Drilling Permits Issued & 50 & 64 & 93 \\
\hline $\begin{array}{l}\text { *No leases issued due to } \\
\text { moratorium }\end{array}$ & & na & \\
\hline $\begin{array}{l}\text { Annual Report } \\
\text { Management, C }\end{array}$ & lifor & av & $\begin{array}{l}\text { of L } \\
1988\end{array}$ \\
\hline
\end{tabular}




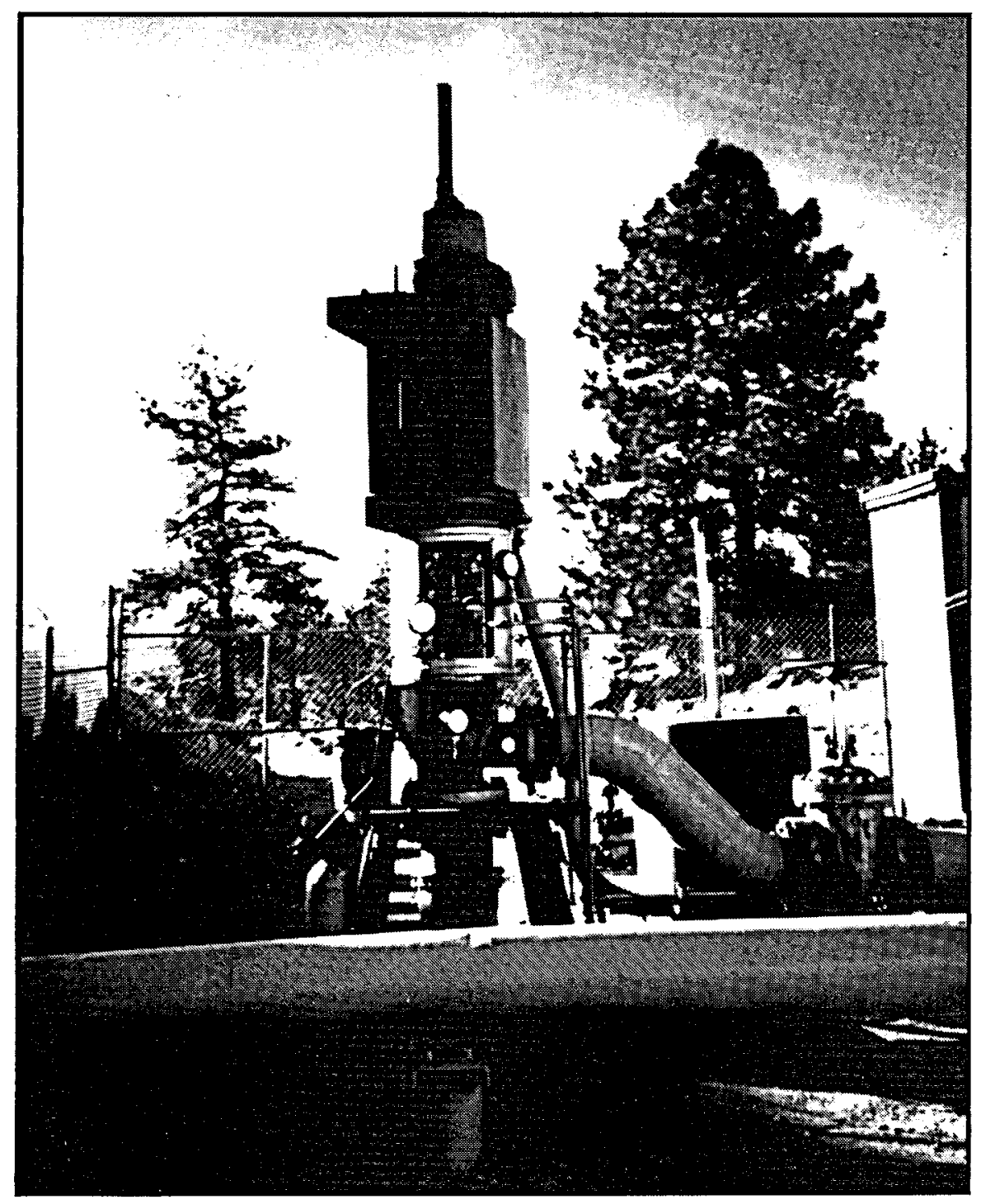

A GEOTHERMAL PRODUCTION WELL AT STEAMBOAT SPRINGS, NEVADA 


\section{CALIFORNIA}

\section{E C G R D A F U N D I N G RECOMMENDATIONS ARE DOWN}

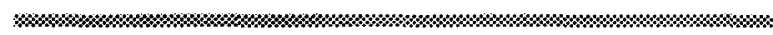

The California Energy Commission sent its FY 1989-90 Funding Recommendations for the Geothermal Resources Development Account to the state legislature in April. For this year's Round 9 funding cycle, the recommendation is $\$ 1.632$ million for eight projects -- down considerably from last year's recommendation of $\$ 4.730$ million for 13 projects and the preceding year's recommendation of $\$ 3.272$ million. The largest chunk of money is the $\$ 395,000$ earmarked for the City of Colton to conduct a resources assessment/drilling project, in contrast to last year's top dollar award of $\$ 1.372$ million for the Town of Mammoth Lakes.

During the preapplication period for Round 9 funding, 18 projects were submitted for a total of $\$ 6.429$ million. By the final request period, eight projects had dropped out, and the total amount requested was pared down to $\$ 3.086$ million. Recommendations by the Technical Advisory Committee brought the total to $\$ 1.964$ million, fairly close to the $\$ 1.632$ million approved by the Commission at its March 15 meeting.

Funding Applicant/Project Recommendation

- Kelseyville Unified School District -- Conduct a resource assessment/drilling project to develop space and water heating at the proposed Riviera Elementary School.

$\$ 149,788$

- City of Clear Lake -- Initiate Phase II of a Hot Dry Rock Investigation. (Under a previous CEC grant, the City identified two potential sites that warrant further investigation.)

$\$ 225,000$

- Lake County - Expand production and irrigation systems of the Geo-Ag project, gaining the ability to operate it as a commercial greenhouse facility.
- City of Colton - Conduct a resource assessment/exploratory drilling program along the San Jacinto fault, which lies between the Cities of Colton and San Bernardino. There are several potential uses in the proposed study area.

$\$ 395,000$

- Mono County - Complete the resource exploration for the Bridgeport Geothermal District Heating Project. Twelve structures, most of them county-owned, are targeted for retrofit.

$\$ 295,000$

- South Lake County Fire Protection District -- Upgrade fire and medical emergency response capabilities.

$\$ 84,000$

- North Sonoma County APCD -- Purchased the Pine Summit monitoring site (the first air quality monitoring station in The Geysers.)

$\$ 82,685$

- Sonoma County -- Reconstruct a portion of the Cloverdale-Geysers Road.

$\$ 166,000^{*}$

Total: $\$ 1,632,137$

* The CEC cut the TAC's $\$ 498,478$ recommendation by $\$ 322,478$.

Source: Geothermal Report 4/1/89 
January, dedication-goers walked away with geothermally-grown plants handed out to commemorate the occasion. In addition to legislators and local officials, VIPs in attendance included Mrs. Neasham and her husband Kip, who donated the property for the agricultural park and center.

Through the $\$ 700,000$ tri-agency effort, Lake County constructed the geothermal system and will lease additional sites on $\mathbf{3 . 5}$ acres for other commercial greenhouse agricultural businesses. MLCCD built the 7,000-square-foot greenhouse and will use it for vocational training and instruction. The CEC's Geothermal Resource Development Account provided funds (nearly onehalf million dollars) for site preparation and construction.

The hot water comes from production wells, drilled to 592 feet and 488 feet, which are located near the site. Water temperature is $63-67^{\circ} \mathrm{C}(145-$ $153^{\circ} \mathrm{F}$ ) and flows at a rate of about $150 \mathrm{gpm}$. After being circulated through a heat exchanger in the greenhouse, the water is injected back underground. Additional commercial facilities can now be built at the site, and the cost of using heat from the system will be calculated as a percentage of competing fuel sources. Growers locating at the center will be provided heat for about 20 percent less than normal heating costs. (The sponsoring agencies estimate an annual savings of nearly $\$ 55,000$ in propane costs.)

An additional \$234,664 award to Lake County from the CEC is pending before the California Legislature. The money is targeted for expanding the production and irrigation system of the Geothermal Agricultural Park.

Source: Geothermal Report 6/15/89

\section{STURGEON ARE BEING RAISED NEAR SUSANVILLE}

Arrowhead Fisheries, northeast of Susanville, is using a $23^{\circ} \mathrm{C}\left(74^{\circ} \mathrm{F}\right)$ geothermal resource at $1,350 \mathrm{gpm}$ to raise sturgeon. The project started in 1986 and has 12 earthen raceways, which measure $10 \times 50$ feet $\times 2$ foot depth. A second site near Likely is about 25 percent larger than the Susanville operation with a flow of about 2,250 gpm.
Source: Geo-Heat Center

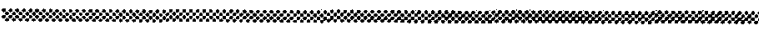 NEW DIRECT USE DEVELOPMENTS IN SUSANVILLE}

Two additional facilities have been connected to the Susanville geothermal district heating system and a new injection well drilled. The first loop of the system, in operation since 1982, circulates $77^{\circ} \mathrm{C}\left(170^{\circ} \mathrm{F}\right)$ fluid to 19 public and commercial buildings and a second loop serves 23 homes. The Roosevelt swimming pool was connected to enable year-round use and the city shops were retrofitted to utilize geothermal space heating. The new injection well, funded by the California Energy Commission and the federal Department of Housing and Urban Development, will alleviate the difficulties the system has had in disposing of waste fluids. The original injection well was inadequate to accept the total discharge, and surface discharge was only temporarily permitted by the State Department of Water Resources which considers these wastes to be hazardous. The new 500-foot injection well will resolve this problem.

\section{Source: Idaho National Engineering Laboratory Regional GeothermalProgress Monitor $5-6 / 87$}

\section{IDAHO}

\section{BOISE, WARM SPRINGS REACH PACT OVER GEOTHERMAL FLUID}

The city of Boise and Warm Springs Water District reached an agreement in December 1988 that at least temporarily heads off a lawsuit over the rights to use an underground reservoir of geothermal water. As a result, 200 homes along Boise's Warm Springs Avenue were guaranteed enough natural hot water to heat their homes for the winter. Boise Public Works director, Bill Ancell, said that a $\$ 16,000$ link between the two geothermal systems will be built at city expense as a backup water supply for Warm Springs. The district has claimed that the city's system has depleted the geothermal aquifer since it began pumping in 1983 to heat the Boise City Hall and several other large downtown buildings. Boise 
previously offered to sell water to the Warm Springs district because of the pressure problem, but the district declined.

Concerned about the dropping geothermal water level prompted the state Department of Water Resources to restrict further development of the aquifer and start extensive studies of the resource.

Terence O'Rouark, chairman of the board of the Warm Springs Water District, said the temporary arrangement should provide the district with time to monitor its geothermal wells and get a better idea of where the resource stands.

The city expects to make back some of its $\$ 16,000$ investment by selling water to Warm Springs for the Idaho State Agriculture Laboratory, which now receives intermittent service from the district when adequate water is available.

The Warm Springs Water district has been pumping the hot water since 1892.

Source: Geothermal Resources Council
Bulletin 4/89

MASSACHUSETTS

\section{RENEWABLE ENERGY PROJECTS DEDICATED IN MASSACHUSETTS}

During "Energy Awareness Week ' 87 " several events highlighted the growing role of renewable energy resources in meeting Massachusetts' energy needs. As part of the week's activities, Secretary Pollard dedicated three projects that utilize solar, hydroelectric, and geothermal power.

The first project dedicated was developed in conjunction with the Boston School Department. Boston English High School is using its newly dedicated geothermal heat pump system to augment heating and cooling the school. The system will displace electrical energy with geothermal energy. Depending on usage patterns and electricity prices, the school could realize savings from $\$ 25,000$ to $\$ 40,000$ per year.

The geothermal heat pump system at Boston English incorporates a 35-ton heat pump, two 1,000-foot wells, a desuper heater, and assorted piping and controls. The geothermal system interfaces with the school's existing HVAC system.

Source: Energy Resources, Winter 1987/88

\section{NEVADA}

\section{WARREN PROPERTIES DISTRICT HEATING SYSTEM EXPANDS}

Warren Properties of Reno, Nevada, has completed Phase I (Warren Estates) with 69 homes connected to a district heating system. The delivery system for the second phase (Manzanita Estates) is installed and lots are sold for an additional 100 homes. Two geothermal wells, Warren Wells No. 1 and No. 2 flow at $97^{\circ} \mathrm{C}$ $\left(207^{\circ} \mathrm{F}\right)$ at $260 \mathrm{gpm}$ and $100^{\circ} \mathrm{C}\left(212^{\circ} \mathrm{F}\right)$ at 450 gpm, respectively, supplying a central plate heat exchanger with a discharge temperature of $48^{\circ} \mathrm{C}$ $\left(118^{\circ} \mathrm{F}\right)$. An injection well is used for disposal. Energy meters are used to bill the customers at a rate 30 percent lower than the price of natural gas (50 percent less if gas furnace efficiency is considered). The only operating problem experienced has been with a water lubricated lineshaft vertical turbine pump; otherwise, the project has been very successful.

Source: Geo-Heat Center

\section{GEOTHERMAL AQUACULTURE RESEARCH CONDUCTED AT HOBO HOT SPRINGS}

The Integrated Prototype Aquaculture Facility (IPAF) at Hobo Hot Springs, Nevada, is used to research geothermal aquaculture and vertically integrated agriculture by Washoe Aquaculture Limited, Gourmet Prawnz Inc., general managing partners. The principal objective at the IPAF is to use geothermal aquifers to raise food, plants, and ornamental fish commercially. The feasibility of geothermal aquaculture has been demonstrated, and the company has implemented many demonstration projects, including the cultivation of freshwater prawns, native baitfish, exotic tropical species, and commercially important aquatic plants. 
Although Hobo Hot Springs is marginal in heat generation and in volume recharge $-43^{\circ} \mathrm{C}$ $\left(110^{\circ} \mathrm{F}\right)$ and $100 \mathrm{gpm}$, respectively -- the IPAF concept is ideal for vertical agriculture integration. As an example, nutrient-rich discharge waters are used to irrigate terrestrial plants, such as Japanese cucumbers, and commercially important aquatic plants for the aquaria market.

The IPAF uses both geothermal and passive solar (greenhousing) alternative energy sources. The efforts to implement such concepts have made a significant impact on Nevada's economic diversification, and because the business is sited on Washoe Indian lands, the Tribe has received economic benefits, as well.

Operations at the IPAF are funded by revenues generated from contract research studies through academia and industry, and by commercial sales of fish and shellfish. The company's products are marketed in California, Idaho, Nevada, and Utah.

Source: Geothermal Hot Line 6/88

\section{ELKO DISTRICT HEATING SYSTEMS EXPERIENCE SIGNIFICANT GROWTH}

Two district heating systems are in operation in Elko, Nevada. Elko Heat Co. is a private company that has experienced considerable growth since it first began operation in 1982 . The project started as a DOE Program Opportunity Notice demonstration project consisting of three buildings: a laundry, bank, and motor hotel/casino. Through innovative marketing, the system has grown to include 12 commercial buildings, two residences, and a sewage treatment plant. This was accomplished by offering a preliminary estimate of customer needs to retrofit their existing heating systems, publicizing the reliability of the system (down less than one day per year), and charging its customers about 50 percent of the price of natural gas $(\$ 1.00$ to $\$ 1.25$ per 1,000 gallons of geothermal fluids). The system supplies about 36.7 billion BTU/year from its one geothermal well that produces 650 gallons per minute at $77^{\circ} \mathrm{C}$ $\left(170^{\circ} \mathrm{F}\right)$. The company has doubled the length of its delivery piping system and has reached the demand point where it will be necessary to drill a second well.

The Elko Schools district heating system, independent of the Elko Heat Company, has been servicing the High School, Junior High School (heat pump system), gymnasium, school administrative offices, convention center, city hall, and municipal pool for about two years. One of the most impressive aspects of this system is the $40^{\circ} \mathrm{C}\left(104^{\circ} \mathrm{F}\right)$ temperature drop through the closed loop servicing the buildings from two plate heat exchangers in parallel. The system supplies about 15.7 billion BTU/year from the $86^{\circ} \mathrm{C}$ $\left(187^{\circ} \mathrm{F}\right)$ artesian well flowing at $300 \mathrm{gpm}$. A unique feature is a safe shut-down control system, designed by an employee of the school, John Belloti, to call him automatically if there is a reduction in pressure. An injection well was drilled but is not used due to concern of contamination of domestic aquifers. Disposal of geothermal fluids is to percolation ponds, storm drains, and to a golf course irrigation system.

Source: Geo-Heat Center

\section{ENERGY AWARD TO MINING COMPANY}

Nevada Governor, Richard H. Bryan, has selected Round Mountain Gold Corporation's geothermally heated heap leach operation for the Governor's Energy Award. The heap leaching operations are located in Big Smoky Valley about 60 miles north of Tonopah.

The system, designed by Geothermal Development Associates (GDA) of Reno, utilizes $700 \mathrm{gpm}$ of $82^{\circ} \mathrm{C}\left(180^{\circ} \mathrm{F}\right)$ geothermal fluid to heat $3,000 \mathrm{gpm}$ of leach solution. With the drilling of new wells in the near future, the plant will be expanded to handle $3,000 \mathrm{gpm}$ of geothermal fluid. This application was engineered by GDA with funds provided by Round Mountain Gold Corporation. It is one of the forerunners of numerous such projects expected in Nevada.

Source: Geothermal Resources Council Bulletin $6 / 88$ 
NEW MEXICO

\section{MUSEUM UTILIZES GEOTHERMAL HEAT}

Visitors to the Geronimo Springs Museum in southern New Mexico are sharing an experience with the museum's namesake and ancient tribesmen. Geothermal energy is providing space heating for the museum at Truth or Consequences. The historic hot spring began heating the museum late last year with help from Western's Conservation and Renewable Energy (C\&RE) cost-shared assistance program.

Facing rising operating costs, the museum had contemplated cutting back services to the community. The geothermal project, however, provided a way to reduce operating costs and increase comfort levels. "This project is very beneficial to the museum and serves as a model for the rest of the community," said Museum Manager Marilyn Pittsenbarger. "We are very grateful for Western's assistance because we would never have initiated the project without it."

In addition to Western, the Sierra Soil and Water Conservation District, New Mexico Solar Energy Institute (NMSEI) at New Mexico State University, and New Mexico Energy, Minerals, and Natural Resources Department teamed with museum personnel in the project.

The project involves pumping $40^{\circ} \mathrm{C}\left(105^{\circ} \mathrm{F}\right)$ water from an 18-foot deep well and piping it through water-to-air heat exchangers in the museum. The well is near historic Geronimo Springs just a few feet from the museum.

\section{Source: Conservation and Renewable Energy Bulletin 6/88}

\section{GEOTHERMAL PROGRAM PUSHES ECONOMIC DEVELOPMENT}

In 1982, the New Mexico legislature provided $\$ 100,000$ to the New Mexico Energy and Minerals Department (EMD) to be spent on cost sharing for drilling geothermal wells. The money was targeted towards private New Mexico geothermal leaseholders with the intent of reducing the risk and cost associated with geothermal exploration and development. The financial arrangement established a 50 percent cost sharing between the State and the leaseholders. The New Mexico State University Energy Institute (NMSUEI) was retained to provide technical and administrative assistance to the EMD and private developers.

The results of this program are positive. Twelve exploratory geothermal temperature gradient holes and nine geothermal production wells were drilled under its auspices. Confirmation of suspected resource areas was successful for eight New Mexico leaseholders and not successful for two others. One large, previously unexplored resource area was partially delineated. The developer believes that this area, located on the Rio Grande Rift near Hillsboro, New Mexico, may be suitable for electricity production.

Five of the production wells are to be used for heating of large structures, primarily greenhouses. Two of the wells will be utilized for low-temperature electricity 'generation using Rankine cycle technology.

A total of 6,362 feet were drilled over the fouryear project period. Temperature gradient holes accounted for 67 percent, or 4,258 feet. Production wells totalled 2,104 feet. New Mexico leaseholders spent over $\$ 120,000$ for drilling and testing and were reimbursed by the State of New Mexico for nearly $\$ 60,000$. The average cost for drilling a temperature gradient well was $\$ 9.40$ / foot while production well drilling costs averaged $\$ 31.63 /$ foot. There was a greater range in well drilling costs for production wells (e.g., from $\$ 21$ to $\$ 83$ per drilled foot) due to different drilling rigs, drilling depths, well diameter, well casing depth, and formations that were encountered.

Although the downturn in prices for conventional fuels has tended to slow the geothermal development process, the success of several of the cost-shared drilling projects will lead to new economic development initiatives within the state. In general, those areas with shallow resource bases (e.g., Radium Springs or Gila Hot Springs) will receive more immediate 
interest while the deeper resource areas (e.g., Hillsboro, Las Cruces, East Mesa) will probably not be developed as rapidly. This phenomenon is principally due to the relativity high capital costs associated with developing the deeper resource areas.

Source: Jack Whittier, New Mexico State University

\section{OREGON}

\section{GEOTHERMAL FLOW REDUCTION ACHIEVED AT OIT}

Geothermal water flow requirements for operating the heating system at Oregon Institute of Technology have been substantially reduced. Due to recent improvements and system repairs, an average flow reduction of 27 percent, or $\mathbf{1 0 0}$ gallons per minute, has been achieved, which means that OIT will now get as much heat as before but from only three-fourths the amount of geothermal water used. It also results in lowered pumping costs for OIT and reduced stress on the geothermal reservoir serving Klamath Falls.

To achieve the savings, workers replaced the main control valves in two OIT buildings and modified controls on a third building.

\section{Source: Geo-Heat Center}

\section{GEOTHERMAL PROJECTS PROGRESSING AT PORTLAND}

Portland's Pinnacle Geotechnical Services, Ltd. brought in a 380-foot warm water well as part of Flemming Corporation's $\$ 8.5$ million shopping center located at S. E. Powell Boulevard and 82nd Avenue. The 10-inch diameter well at the shopping center would be capable of supplying $1,000 \mathrm{gpm}$ at about $16^{\circ} \mathrm{C}\left(60^{\circ} \mathrm{F}\right)$, although only about 10 percent of that capacity will be necessary for the project, according to Gerald $O$. Thompson, Pinnacle vice president. A shallow injection well is expected to be used for effluent disposal. The geothermal heat pump system is expected to be a big plus in getting tenants in the four building, 117,674-square-foot shopping center because it should lead to much more stable energy costs. Powell Street Station could be the forerunner of several metropolitan Portland commercial developments using geothermal energy for heating and cooling.

Source: Geo-Heat Center

\section{UTAH}

\section{LDS CHURCH INVESTIGATING USE OF GEOTHERMAL ENERGY}

The Church of Jesus Christ of Latter Day Saints is reviewing the potential for geothermal resource utilization for its facilities throughout the western U.S. Space heating costs for a typical chapel run from $\$ 1,000$ to $\$ 3,000$ per month, and the Church is searching for various ways to reduce these costs. The Church has more than 300 properties in Utah alone and believes that some of these are likely connected with geothermal resources. In addition, land purchase for new chapels, farms, and other properties is an ongoing effort, and geothermal resource potential could influence these purchases. Because of the large number of LDS Church properties throughout the western United States, there is some possibility that eventually, supported by a favorable early experience, the Church could become one of the largest direct heat users of geothermal energy.

The Church has been advised in its review by the University of Utah Research Institute which has provided the data base developed by the DOE State Cooperative Program, including the Geothermal Resource maps for all of the western U.S.

Source: Idaho National Engineering Laboratory Regional Geothermal Progress Monitor $1-3 / 88$ 


\section{PARIS ECONOMIC SUMMIT}

The seven world leaders meeting in Paris in July 1989 at the Summit of the Arch "strongly advocated common efforts to limit emissions of carbon dioxide and other greenhouse gases." Recognizing the role of energy in threatened global climate changes, the Economic Declaration of the Summit urged the promotion of "relevant (energy) techniques and technologies."

Without direct reference to renewable energy technologies, or to geothermal specifically, the Declaration called for environmental considerations in economic decision-making and for marketing of cost-effective clean technologies. The World Bank and regional development banks were encouraged to integrate environmental considerations into their activities. International organizations such as the OECD and the United Nations and its affiliated organizations were asked to develop further techniques of analysis which would help governments assess appropriate economic measures to promote the quality of the environment.

For the many developing countries endowed with geothermal energy, use of this resource appears to be a "natural" in response to these energy/economic/environmental declarations of the Summit. It has a proven track record for discharging minimal, if any, $\mathrm{CO}_{2}$ emissions; it is a local, indigenous resource; and a suitable resource, which, when properly developed, is a cost-effective fuel. By using their indigenous geothermal resources, the oil importing nations would save capital for other facets of economic development, and oil exporting countries would make more oil available for export, thus raising more capital for other uses.

\section{ITALY SELECTED TO HOST FIRST INTERNATIONAL GEOTHERMAL SECRETARIAT}

The initial meeting of the International Geothermal Association (IGA) was held in May 1989 at Castelnuovo, Italy, where the Secretariat of the Association will be located until February
1991. This meeting was also the final meeting of the Organizational Working Group (OWG - IGA) which was formed in 1987 to develop the charter, bylaws, and organization of the IGA. Composed of interested individuals from throughout the world, the OWG - IGA formally relinquished all of its functions to the first IGA Board of Directors at the May meeting.

The IGA charter proclaims the IGA to be a scientific, educational, and cultural organization established to operate worldwide. It is a nonpolitical affiliation. Its aim is to encourage, facilitate, and, when appropriate, promote coordination of activities related to worldwide research, development, and application of geothermal resources. The organization is incorporated in New Zealand.

Dr. James B. Combs of Geothermal Resources International is serving as IGA's charter president and Enrico Barbieri, editor of Geothermics, as general manager. The location of the Secretariat will be rotated with the U.S. serving as second host. This term is anticipated to begin in February 1991 and run until February 1995. It is expected to be located in California.

Source: Geothermal Resources Council
Bulletins 4/88 and $1 / 89$ and
Communication with David W.
Anderson 8/15/89

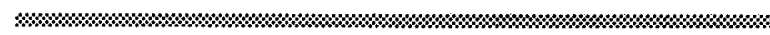
CHINA'S GEOTHERMAL POTENTIAL

On a visit to the U.S., Dr. Ji-yang Wang, of the Institute of Geology, Chinese Academy of Sciences, Peoples Republic of China, addressed the Environmental and Energy Section of the Commonwealth Club of San Francisco on the "Status of Geothermal Studies in China."

The announcement of the talk quoted an Electric Power Research Institute estimate that China "has the world's largest geothermal energy potential -- 535,000 MWe for at least 30 years." Statistics provided by Dr. Wang (see table below) indicate that China has identified $\mathbf{1 . 0 9 6}$ million MWe of geothermal resources, as well as 2.1 million MWe of "possible" resources. Although the geothermal resource is small compared to others (less than $1 \%$ ), it is very important to specific 
geographic areas and will help China extend the life of its coal resources (.09 billion tons).

\section{RESOURCE ASSESSMENT}

(in megawatts)

\section{Identified Possible}

\section{Convective}

\begin{tabular}{|c|c|c|}
\hline \multicolumn{2}{|l|}{ ah Temne } & $\begin{array}{l}220 \\
494\end{array}$ \\
\hline Conductive & & 6,095 \\
\hline & & 809 \\
\hline
\end{tabular}

(Source: 1985 data released by the Ministry of Geology)

China has an energy shortage problem, Dr. Wang noted, and geothermal resources are becoming increasingly important.

Forty geothermal fields, out of a total of 3,000 in China, have been or are being explored and assessed. Low-temperature fluids are most common, with the high-temperature resources concentrated in regions of recent volcanic and tectonic activity, such as Tibet. Tibet lacks the oil and coal resources common in other parts of China, and hydropower is limited because of cold winters. Thus, geothermal energy is a good solution, and an $8 \mathrm{MWe}$ plant serves Lhasa. Five smaller experimental plants, ranging from 50 to $300 \mathrm{~kW}$ are in operation; about half are flash steam and half dual fluid cycle.

Because of the prevalence of lowtemperature fluids, direct use applications are more common and are growing in number. The uses include industrial processing, chemical extraction, space heating and hot water supply, bottled mineral water, health and recreational uses, and greenhouses.

China is expanding its knowledge of geothermal technologies to support additional development. Dr. Wang stated that a number of countries (including Iceland, Italy, Japan, and the U.S.) have shown interest in working with the Chinese to develop geothermal potential. Interested parties can contact Dr. Wang at:
Laboratory for Geothermics

Institute of Geology

Academic Sinica

P.O. Box 634

Beijing, China

Phone: 44-6651, x 332

Cable: 6347 Beijing, China

Telex: 22474 ASCHICN

Source: Geothermal Report 9/15/87

\section{GEOTHERMAL PROJECT PLANNED FOR TIBET}

The Lhasa Travel Service and Shelter International (US) jointly plan to build a power station and hotel to use solar and geothermal energy at Maizhokunggar, Tibet, according to South Publication Ltd., New Zealand House, London.

Source: Geothermal Report 9/1/87.

\section{REPORT CITES LOW-TEMPERATURE GEOTHERMAL POSSIBILITIES IN NOVA SCOTIA}

Nova Scotia's Picou Basin presents opportunities to use low-temperature geothermal brines found in conventional aquifers and in water-filled mines. A report by Novacorp International Consulting, Ltd., and Davis and Associates, Ltd., said a project using the geothermal waters could be supported by Highland Square Mall and Aberdeen Hospital/Glen Haven complex, each now generating energy bills exceeding $\$ 500,000$ a year. Other users could be served, and new industries, such as greenhouse agriculture, might be attracted. Energy, Mines and ResourcesCanada, an Ottawa publication, reported that this is the only project in Canada currently promoting use of low-temperature geothermal energy.

Source: Geothermal Report 9/1/87. 


\section{J A P A ESE A N NOU NCE GEOTHERMAL PLANS}

The Japanese announced in February 1989 that the world's first self-sufficient, geothermallypowered, planned community is being constructed on the Japanese island of Kyushu by Canadian, American, and Philippino workers.

More than $\$ 1$ billion has been invested so far by Japan's Ministry of International Trade and Industry (MITI) in order to finance exploration of that country's geothermal resources. In addition to that amount, the Fujita Corporation -- one of Japan's largest construction firms -- has invested more than $\$ 125$ million in the operation to date. It is believed that this project has the potential to dwarf California's The Geysers field, the world's largest geothermal field, which is capable of supplying all of the electricity needs of San Francisco and much of the northern California demand.

The goal of the project is the construction of an underground plant that will produce a massive amount of low-priced, clean electricity. The facility, located on the flank of one of the world's largest volcanic craters (Mt. Aso) will eventually be teamed with several other plants - now in the planning stages -- to produce up to 3,000 MWe of electricity within the next decade. That amount is sufficient to meet the requirements of as many as 3 million people.

One of the three existing production wells was tested at a mere $20 \mathrm{MWe}$. The first power plant will generate $250 \mathrm{MWe}$, making it the world's largest.

The most interesting aspect of this project is the fact that the Japanese principals are actively encouraging American investors (as well as other members of the international community) to join in the project. Investor participation is being offered to Americans -- an opportunity that has no precedent in recent U.S.- Japan trade relations.

Source: Geothermal Resources Council Bulletin 3/89

\section{DJIBOUTI TO REPLACE DIESEL- FIRED POWER WITH GEOTHERMAL}

With financial backing from The World Bank/IDA, Italy/ENEL, and OPEC/UNDP, Djibouti plans to replace its $88 \mathrm{MWe}$ (163 GWh/yr @ $21 \phi /(\mathrm{kWh})$ diesel-fired electrical system with a geothermal system. Economic studies by the OPEC Fund and Electroconsult concluded that geothermal would be competitive with diesel if oil prices were $\$ 17 /$ barrel or more in 1983 dollars.

An initial $\$ 38$ million program will develop two 5-MWe back pressure geothermal units $10 \mathrm{~km}$ southeast of Lake Assal (a salt lake located in the Danakil Depression some $14 \mathrm{~km}$ inland and 155 $\mathrm{m}$ below sea level) and the Ardoukaba volcano on the southern flank of the volcanically active Assal Rift by 1992 . A $132 \mathrm{kV}, 100 \mathrm{~km}$ transmission line will be installed to connect to Djibouti City. Delivered costs are estimated at $10 \phi / \mathrm{kWh}$.

A $1 \mathrm{MWe}$ wellhead generator and electrically powered desalination plant (\$1.4 million) will be installed in 1990 at the desert site to furnish fresh water at the plant site utilizing the saline marine waters of nearby Gulf of Ghoubet.

Source: Geothermal Energy Institute, 8/10/89

GREENHOUSE PROJECTS IN
OPERATION IN GREECE; ADDITIONAL
RESOURCE EVALUATION UNDER
WAY

A major demonstration of greenhouse agriculture using geothermal heat is under way in Greece, with the European Economic Community and Greek financing institutions and technical universities participating.

Two greenhouses, one of four acres with a plastic covering and the second occupying two acres covered with glass, were completed last year. The project is experimental and demonstrational and is to run five years. It is located in the North Kessanis community and uses the energy resources of the North Kessanis geothermal area. The electromechanical 
equipment was designed with available Greek technology and is fitted to conditions prevailing locally. The idea is to make replication feasible in other areas.

The budget for the five-year project, which is designed to collect data that may be useful in other direct use projects in the country and also to assist the local economy, may run to 1.189 billion drachmas, of which the EEC has pledged 70 percent under its VALORIN program. The remaining 30 percent will be Greek national investment. Participating institutions include the Greek Bank of Industrial Development, the Agricultural Bank of Greece, IGME, the Polytechnic University, and Geoponic University.

According to the Greek Institute of Geology and Mineral Exploration, several geothermal greenhouse applications and one eel farm are in operation in central Macedonia, and other lowtemperature fields are under investigation.

A research project to investigate the potential for geothermal power generation and/or direct use applications at Argenon on the island of Lesuas is also under way. This project, 180 miles northeast of Athens, is funded by a combination of powerful Greek government agencies and the European community. The target area is described as one of the most important middle enthalpy fields in Greece.

Sources: Geothermal Report 7/1/88, 9/1/88, and $11 / 15 / 88$

\section{GEOTHERMAL SURGE PREDICTED FOR CENTRAL AMERICA}

Geothermal electric generating capacity in Central America (defined as Guatemala, Honduras, El Salvador, Costa Rica, and Panama) could more than quadruple between now and the end of the century. That is the positive conclusion drawn by Los Alamos National Laboratory's Linda K. Trocki and Robert J. Hanold, writing in the September/October 1988 issue of the Geothermal Resources Council Bulletin. The authors report that geothermal energy "compares favorably with the cost of the alternatives" and is expected to account for "at least 10 percent of Central America's electric generating capacity" by the year 2000 .
Plans for installation of $405 \mathrm{MWe}$ of new geothermal electric generating capacity in Costa Rica, El Salvador, and Guatemala are "relatively firm," and an additional 200 MWe throughout the area, including Honduras and Panama, is possible. Combined with the existing $95 \mathrm{MWe}$ in El Salvador, geothermal capacity could reach up to $700 \mathrm{MWe}$.

The authors cite several reasons for this, among them recent difficulties experienced by newly developed large hydroelectric projects (technical failures, cost overruns, lack of reliability during this year's drought), which may result in the substitution of geothermal for hydropower in certain instances. The preference for using indigenous resources in order to reduce costly imports and to provide local jobs is also a factor. Too, geothermal is amenable to phased expansion and small capacity increments, a situation which presents attractive financing opportunities. Geothermal might also have an application in isolated areas, traditionally served by diesel generators, where "it is possible that small, modular, factory-assembled geothermal binary units could play a role."

Although the authors caution that the advantages of geothermal must be determined on a case-by-case basis, their bottom line is that "geothermal will play a significant role in additions to capacity and may also be important in process heat applications by the region's industries."

\section{Source: Geothermal Report 11/1/88}

\section{MEXICO MOVES INTO THIRD PLACE IN GEOTHERMAL POWER}

Mexico moved into third place behind the U.S. and the Philippines in installed geothermal capacity for generating electricity in 1987 when Cerro Prieto II and III came on line with four 110MWe plants, raising the total national installed capacity to $650 \mathrm{MWe}$. Although Cerro Prieto in Baja California and Los Azufres in the State of Michoacan are the only geothermal fields presently in commercial production, two others (La Primavera in the State of Jalisco and Los Humeros in the State of Puebla) should come into production in the near future, and feasibility studies are under way at 18 additional sites. 
Geothermal energy receives 18 percent of the country's total alternative energy budget. Exploration, development, production, and achievements are the work of the Geothermal Bureau, under the Federal Electricity Commission (CFE). Hector Alonso, Director of the Bureau since 1982, says he feels "very good" about three major achievements in the past four years. "First, we are manufacturing wellhead units in Mexico. Although we now import 40 percent of the component parts, our goal is to produce all the parts locally and, by the year 1990 , to make the entire mobile unit in Mexico. Second, we brought four new turbogenerators that generate $110 \mathrm{MWe}$ each into production; and third, we identified and are drilling at a new field: Los Humeros!" Despite cutbacks in budgets and investment during the past four years caused by the nation's severe economic problems, geothermal energy showed a growth rate of 215 percent, a mere 5 percent drop from the rate in 1982. Proven reserves grew to 1,220 MWe, probable reserves are estimated at 4,800 MWe, and possible resources now stand at $7,000 \mathrm{MWe}$. A total of $1,650,421 \mathrm{MWe} / \mathrm{h}$ of electricity were produced by geothermal wells in 1985: $1,480,495 \mathrm{MWe} / \mathrm{h}$ from Cerro Prieto, and 169,926 MWe/h from wells at Los Azufres. Cerro Prieto has 620 MWe of installed capacity and another 220 MWe programmed for the next five years. At Los Azufres, $50 \mathrm{MWe}$ are under construction.

Mexico's long term goal is to become the second largest generator of geothermal electricity by 1995 , with an installed capacity of 1355 MWe.

Source: Geothermal Report 6/15/87

\section{ARGENTINA INSTALLS FIRST GEOTHERMAL POWER STATION}

On April 5, 1988, engineer Luis E. Galardi, Secretary of Energy and Mining of Neuquen Province, announced that the Republic of Argentina's first geothermal power plant had been installed. This plant is also the first of its type installed in South America and is part of Argentina's provincial exploration program.

The Copahue Power Station is in the Copahue geothermal field, in Neuquen Province, which is located in west central Argentina. Electrical energy is produced with a $600 \mathrm{~kW}$, remote controlled, binary cycle unit using isopentane as a power fluid. This pilot unit operates on one well which produces "dry steam" at a temperature of $170^{\circ} \mathrm{C}\left(338^{\circ} \mathrm{F}\right)$ at a "well head" pressure of $8 \mathrm{~kg} / \mathrm{cm}^{2}$. Power is sold to the government of Neuquen Province and the plant is operated by Neuquen Province Energy Company (E.P.E.N.), address: Rioja 385, 8300 Neuquen, Argentina.

At this time, plans for future wells and power plants are unknown.

Source: Geothermal Resources Council Bulletin $6 / 88$

\section{KAWAH KAMOJANG GEOTHERMAL POWER DEVELOPMENT, INDONESIA}

Electricity flowed into Indonesia's national grid in July 1987 from the 55 MWe Unit 2 at the Kawah Kamojang Geothermal Project, marking the first step towards full production from the second stage of the project. Unit 3, also $55 \mathrm{MWe}$, was completed in September 1987, significantly ahead of schedule and under budget. Completion of these two units raises the total capacity of the plant to $140 \mathrm{MWe}$.

The first stage saw the commissioning of the 30 MWe Unit 1 in November 1982. Built under New Zealand's largest single bilateral aid project, the plant became Indonesia's first commercial geothermal power station. This followed directly from successful exploration and drilling programs which culminated in the discovery of the dry steam reservoir.

Source: Geothermal Resources Council Bulletin 9-10/87

\section{UNOCAL SIGNS CONTRACT IN INDONESIA}

Unocal Corporation announced in January 1989 that it has given the Indonesian government notice of intent to proceed with a geothermal project to provide steam for a 110,000 kilowatt electrical generating plant. 
Under a joint operation contract, Unocal Geothermal of Indonesia, Ltd., a wholly owned Unocal subsidiary, discovered a geothermal field in the Gunung Salak area, approximately $\mathbf{4 0}$ miles south of Jakarta. The company has drilled eleven wells, and has confirmed reserves for more than 230,000 kilowatts of generating capacity.

Indonesia's state electric company, PLN, will build the power plant with loans from the Italian government. Ansaldo, an Italian company, will supply equipment and manage the construction. Construction will begin in 1989 with the power plant expected to come on-line in 1992.

With the notice of intent to proceed, Unocal Geothermal of Indonesia, Ltd., will begin drilling additional wells and build the field facilities necessary to provide steam to the power plant.

Source: Geothermal Resources Council Bulletin $2 / 89$

\section{COMPLETE GEOTHERMAL WELL COMPLETE GEOTHERMAL WELL LOGGING SYSTEM SUPPLIED BY CISE TO BOLIVIA}

Cise of Milano, Italy, has supplied a complete well-logging system for real time temperature and pressure measurements in geothermal wells to the Bolivian Ente Nacional de Electricidad (ENDE) for the development of geothermal resources in the Laguna Colorado area.

Source: Geothermal Resources Council Bulletin $6 / 88$

\section{KENYA AND NEW ZEALAND PROJECTS DESCRIBED}

The International Development Agency has loaned Kenya $\$ \mathbf{4 0 . 7}$ million, according to Modern Power Systems of London, to help finance a 20year program of geothermal development and pre-construction studies and research of energy related problems, from hydro prospects to pricing and rural electrification.

In the same issue (May 1989), the publication described New Zealand's newly commissioned
Ohaaki geothermal plant 22 kilometers from the Wairakie station, which has been operating since 1958. Four turbo-generator sets are to be installed, MPS reported, each of 11.2 MWe capacity, that have been refurbished after use for 20 years until 1982 at the Wairakie plant. Reduced steam pressure made them uneconomical at Wairakie. While both the Wairakie and the new $\$ 185$ million Ohaaki plant are in the Broadlands KGRA on the North Island, they are described as being completely separate.

Source: Geothermal Report 7/1/89

\section{DISTRICT HEATING SYSTEM IS OPERATING IN SOUTHAMPTON}

A geothermal energy project coldshouldered three years ago by the British government is now providing an economic source of heat for a group of public buildings in the seaport city of Southampton.

Costing 3.8 million British pounds, the scheme is the first in Britain to tap heat from a geothermal aquifer for district heating. Aquifers are rock formations that hold water, and Southampton's is formed by 200 -million-year old Triassic Sherwood sandstones 1,700 meters below the city.

The rocks are hot and porous, and act rather like a giant sponge $\mathbf{7 0}$ meters thick. Trial drilling revealed that part of the "sponge" is particularly permeable and constitutes a huge resenoir of water at a temperature of $76^{\circ} \mathrm{C}\left(169^{\circ} \mathrm{F}\right)$.

The city council is pumping the water to the surface, transferring it to a heat station, and then distributing it along a network of underground pipes to buildings in the city center. The council's civic center, its main offices, and institute of higher education are being heated by the water through underground pipes extending up to 2 kilometers from the heat station. Hotels and private offices are next in line for connection to the system, followed by houses and flats.

The scheme is controlled by a heat station 200 meters from the wellhead, where the briny water is pumped to ground level at a rate of about 12. liters per second. At the station the heat from 
the brine is transferred to the hot-water distribution system. The process uses a heat exchanger coated with titanium as well as filtration equipment for water and brine.

When the heat from the geothermal station is supplemented by existing boilers at the college and the civic center, the whole scheme will eventually have a potential capacity of 24,000 kilowatts, large enough to supply the heating needs of most of the city center.

Source: New Scientist, July 1988

\section{CONFERENCE ON RENEWABLE ENERGY IN THE AMERICAS HELD}

Jointly sponsored by the U.S. Export Council for Renewable Energy (USECRE) and the
Committee on Renewable Energy Commerce and Trade (CORECT), a conference and trade fair called Renewable Energy in the Americas were held in Miami, May 30 - June 3, 1989. The emphasis was on sales of U.S. renewable energy technology in Latin America, and good attendance from the target countries was reported. Over 70 exhibitor booths were featured, including one sponsored by the National Geothermal Association (NGA). Geothermal personnel from the University of Utah Research Institute presented a well-attended, half-day session on U.S. geothermal products and services.

USECRE is composed of nine trade organizations including NGA. CORECT is described in INDUSTRY SCENE in an article entitled "Geothermal Industry Looking to Foreign Markets." 


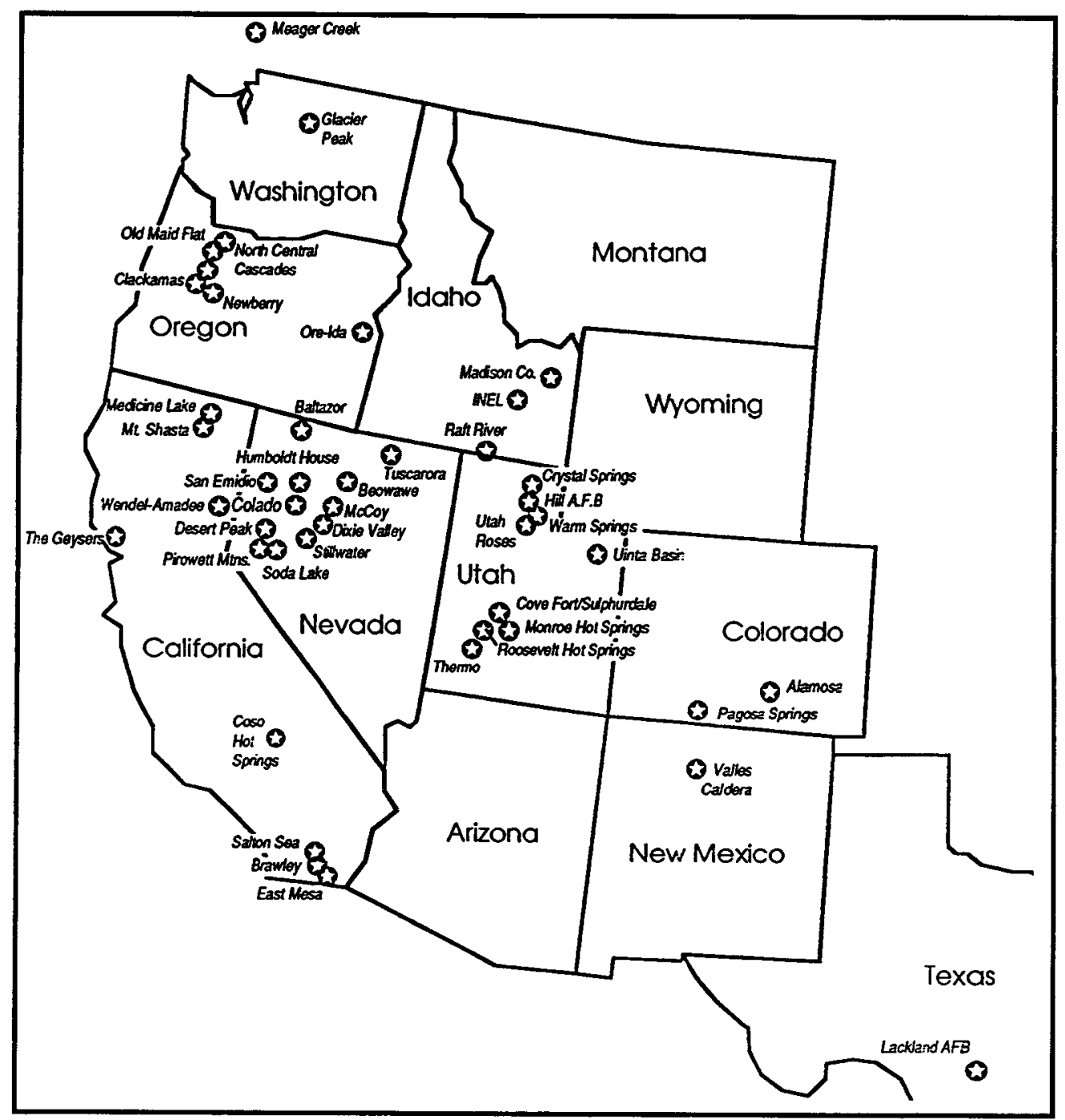

LOCATIONS OF AREAS REPRESENTED BY SIGNIFICANT

DRILL SAMPLES AT THE GEOTHERMAL SAMPLE LIBRARY

AT THE UNIVERSITY OF UTAH RESEARCH INSTITUTE

(See Page 61.) 


\section{GEOTHERMAL SAMPLE LIBRARY AVAILABLE AT UURI}

The Geothermal Sample Library at the University of Utah Research Institute provides open-file accessibility and archival storage for both public domain and proprietary field and drill samples. At present, the Library contains over 80,000 meters of drill samples and 25,000 meters of core from more than 180 shallow thermal gradient holes and deep holes, mainly from geothermal areas of the western United States. Included are samples from 14 Industry Coupled Program areas in Utah and Nevada; Coso KGRA, California; Raft River, Idaho; and Cascades Range, Oregon; and samples from DOE and private geothermal projects in Wyoming, Colorado, Idaho, Washington, Oregon, California, and New Mexico. The Industry Coupled Program was an early DOE effort to make geothermal data available to the public through cost- and risksharing with industry.

The UURI sample library has been used to archive samples from DOE projects and to distribute samples for authorized research and study. It has been used to advantage by geologists and researchers in preparation for new drilling within the represented areas, and for comparison with drill samples from their own project areas. Chipboards have been prepared for most DOE-supported geothermal holes in order to facilitate study. Downhole geophysical and temperature logs from many geothermal wells are also archived at UURI.

A map showing the locations of the drill hole sites where the samples originated is shown on Page 60. A current inventory of drill core and cuttings curated at the Library is included in the Laboratory's publication "Geothermal Studies at the University of Utah Research Institute."

\section{GEO-HEAT CENTER PUBLISHES GEOTHERMAL DIRECT USE GUIDE}

The Geo-Heat Center at Oregon Institute of Technology has published a Geothermal Direct Use Engineering and Design Guidebook. Funded by the U.S. Department of Energy and supported by the Idaho National Engineering Laboratory, the book was co-edited by Paul J. Lienau, Director of the Center, and Ben C. Lunis of INEL.

Ten expert authors, including Lienau and Lunis, contributed chapters to the book. Subject matter ranges from the nature of geothermal resources to exploration, fluid sampling techniques, drilling and completion of geothermal wells, well testing, and reservoir evaluation. The book also presents information useful to engineers on the specification of equipment including well pumps, piping, heat exchangers, space heating equipment, heat pumps, and absorption refrigeration. A compilation of current information about greenhouse, aquaculture, and industrial applications is included together with a discussion of engineering cost analysis, regulation requirements, and environmental considerations. Special attention has been paid to unification of expert knowledge drawn from years of experience in order to ensure an integrated view of direct uses of geothermal energy.

The book may be ordered from the GeoHeat Center, Oregon Institute of Technology, 3201 Campus Drive, Klamath Falls, OR 97601. The price is $\$ 20$ ( $\$ 27$ in U.S. dollars on foreign orders).

\section{FORUM ON RENEWABLE ENERGY AND CLIMATE CHANGE HELD IN WASHINGTON, D.C.}

With multiple sponsors, a Forum on Renewable Energy and Climate Change was held in June 1989 in Washington, D.C. Its focus was the need for environmentally clean energy technologies to help solve the global warming problem.

The Environmental Protection Agency presented the results of its impact studies on global warming. The analysis demonstrates that new clean sources of energy are necessary for the United States. Industry reported on the amount of air emissions already eliminated through use of solar/renewable energy resources and what could be done if commercialization of clean energy alternatives is accelerated. To conclude the meeting, a roundtable panel 
considered policy options for encouraging more rapid expansion of clean energy technologies while maintaining efficient and uninterrupted energy supplies.

Dr. Robert L San Martin, Deputy Assistant Secretary for Renewable Energy of DOE, provided statistics to show that, from a historical perspective, the mix of fossil-fired electric power generation in the U.S. in 1986 produced an average of 874 metric tons of $\mathrm{CO}_{2} / \mathrm{GWh}$, while renewable energy technologies produced an average of approximately 18 metric tons of $\mathrm{CO}_{2} / \mathrm{GWh}$. Thus, each $\mathrm{GWh}$ from renewable energy, he pointed out, displaced approximately 856 metric tons of $\mathrm{CO}_{2}$, or a 98 percent reduction.

From a future perspective, he added, projections to 2010 indicate that renewable energy electric technologies could reduce $\mathrm{CO}_{2}$ emissions by 519 million metric tons per year in the U.S., or an 18 percent displacement of $\mathrm{CO}_{2}$ related to an equivalent electrical output from fossil-fired power facilities.

Sponsors of the Forum included:

Committee on Renewable Energy Commerce and Trade

U.S. Export Council for Renewable Energy

U.S. Environmental Protection Agency

California Energy Commission

World Resources Institute

Arizona Energy Office

The Climate Institute

\section{REPORT ON NEW MEXICO COST. SHARED DRILLING PROGRAM IS AVAILABLE}

In 1982, the New Mexico legislature provided $\$ 100,000$ to the New Mexico Energy and Minerals Department to be spent on cost-sharing for drilling geothermal wells. The money was targeted toward private New Mexico geothermal leaseholders to reduce the risk and cost of further delineating the low-temperature geothermal energy resource base in areas that are prime targets for the commercialization of geothermal energy technology. The final report on this program entitled "New Mexico Cost-Shared Drilling Program" may be obtained from New
Mexico Minerals and Energy Department, Geothermal Division, 525 Camino de los Marques, Santa Fe, NM 87501. The report contains temperature vs. depth data, lithologic logs, and site locations for all wells drilled under the program.

Publication of this report was followed by the 2nd Geothermal Commercial Greenhouse Symposium, February 22 and 23, 1988, on the campus of the New Mexico State University at Los Cruces. Information on the symposium may be obtained from Dr. Rudy Schoenmachers, P.O. Box 350L, Los Cruces, NM 88003.
Source: Idaho National Engineering Laboratory Regional Geothermal Progress Monitor 5-6/87, 12/87

\section{SYMPOSIUM PROMOTES GEOTHERMAL GREENHOUSE DEVELOPMENT IN NEW MEXICO}

Nearly 50 persons involved in the greenhouse industry, real estate, geothermal, and horticultural research and development, and economic development attended the second symposium February 21-23, 1988, at New Mexico State University, Las Cruces, N.M. The event was coordinated by the New Mexico Solar Energy Institute at NMSU, the New Mexico Research and Development Institute, NMSU Department of Horticulture, the Western Area Power Administration, and several local greenhouse businesses. The objective of the event was to promote commercialization of greenhouses in southern New Mexico.

Source: Idaho National Engineering Laboratory Regional Geothermal Progress Monitor $1 / 3 / 88$

\section{NEW GEOLOGIC MAP FOR OREGON HOT SPRING AREA RELEASED}

A new geologic map published by the Oregon Department of Geology and Mineral Industries (DOGAMI) and partially funded by the U.S. Department of Energy provides a detailed 
geologic description of the McKenzie Bridge 15minute quadrangle in the Cascade Range.

Geologic Map of the McKenzle Bridge Quadrangle, Lane County, Oregon was prepared by G.R. Priest, G.L. Black, and N.W. Woller of DOGAMI, and E.M. Taylor of Oregon State University. It was published in DOGAMI's Geological Map Series as Map GMS-48.

The McKenzle Bridge quadrangle is located at the transition zone between the older Western Cascades and the younger High Cascades. This zone is also the location of some of the hottest known thermal springs in the Cascade Range. A major purpose of the study that culminated in the production of this map was to define the structure of the area in greater detail.

The report consists of two map sheets and a five-page text discussing the map data. The fullcolor geologic map at a scale of 1:62,500 (Plate 1) identifies 56 surficial, volcanic, and intrusive rock units and their structural relations and is accompanied by four cross sections. The second sheet (Plate 2) contains index and samplelocation maps and three tables showing chemical analyses and radiometric ages of rock samples. The text discusses the structural geology, paleogeographic history, and mineral and geothermal resources of this complex geologic boundary.

The report is now available at the Oregon Department of Geology and Mineral Industries, 910 State Office Building, 1400 SW Fifth Avenue, Portland, OR 97201-5528. The price is $\$ 8$. Orders under $\$ 50$ require prepayment.

\section{GEOTHERMAL INNOVATIVE TECHNOLOGIES CATALOG}

In July 1988, the Geothermal Technology Division of the U.S. Department of Energy published the Geothermal Innovative Technologies Catalog. This document contains descriptions of over 80 research projects that resulted in the development of hardware, techniques, handbooks, or software designed for those who are exploring, developing, or using geothermal resources. The major portion of these projects have been terminated at the end of the research phase and as a result, the work is either unavailable or unknown to the geothermal community.

The objective of this publication is to encourage industry to take these projects over, do what is necessary to bring them to the market place, and make them available to the geothermal community.

For more information contact Ralph Burr, Geothermal Technology Division, U.S. Department of Energy, 1000 Independence Avenue, Washington, D.C. 20585, (202) 586-5335.

\section{MAGNETIC ANOMALY MAPS OF NEVADA}

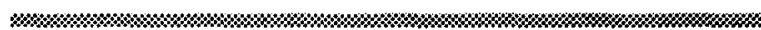

The Nevada Bureau of Mines and Geology has published two magnetic map sets prepared by Thomas G. Hilderbrand and Robert P. Kucks of the U.S. Geological Survey. NBMG Map 93A is a 1:750,000-scale total intensity magnetic anomaly map of Nevada, compiled from digital data, corrected to a common surface $1,000 \mathrm{ft}$. above ground.

NBMG Map 93B is a set of four $1: 1,000,000$ scale and two 1:2,000,000-scale filtered magnetic anomaly maps of Nevada created by applying a variety of analytical techniques to digital data. The filtering operations performed were: reduction-to-the-pole, first vertical derivative, pseudo-gravity transformation, horizontal gradient to pseudo-gravity, and shaded magnetic relief analysis. A considerable amount of lithologic and structural information can be derived from study of these filtered anomaly maps.

NBMG Map 93A is available for $\$ 7.00$ and NBMG Map 93B for $\$ 10.00$ at the NBMG Sales Office (Room 310, Scrugham Engineering-Mines Building, University of Nevada campus in Reno). They may be mail-ordered for $\$ 7.70$ and $\$ 11.00$, respectively, from: Nevada Bureau of Mines and Geology, University of Nevada-Reno, Reno, NV 89557-0088. If ordering by mail please prepay by check or money order made out to Board of Regents-UNR.

For further information, call (702) 784-6691. 


\section{BREITENBUSH AREA OF OREGON REPORT RELEASED}

A new geologic report on studies of an area that includes the Austin and Breitenbush Hot Springs, both so-called Known Geothermal Resource Areas (KGRA) in the Cascade Range, presents a geologic cross section and geothermal model in greater detail than had been possible so far.

The Oregon Department of Geology and Mineral Industries (DOGAMI) has released Geology and Geothermal Resources of the Breitenbush-Austin Hot Springs Area, Clackamas and Marion Counties, Oregon, as DOGAMI OpenFile Report 0-88-5. The report was edited by D.R. Sherrod of the U.S. Geological Survey (USGS) and contains contributions by Sherrod and five other scientists from the USGS, Washington State University, and Southern Methodist University.

The report summarizes several ongoing investigations, including geologic mapping, alteration studies, and the heat flow results from cooperative and industrial drilling programs. The researchers were able to use, for the first time, previously confidential information from industry drilling.

The first five chapters present detailed treatments of the geologic setting, stratigraphy, geochemistry, alteration phenomena, and a substantial set of new data on thermal conductivity and heat flow. In the final chapter, all the contributions are combined into a geologic cross section showing topography, stratigraphy, structure, isotherms, heat flow, gravity, and hydrology.

The 91-page report is accompanied by a geologic map and cross section of the area around geothermal drill hole CTGH-1, located about $14 \mathrm{~km}$ ( $8.7 \mathrm{mi})$ northeast of Breitenbush Hot Springs and $6 \mathrm{~km}(3.7 \mathrm{mi})$ northwest of Olallie Butte. This hole was rotary-drilled cooperatively by Thermal Power Company, Chevron Geothermal, and the U.S. Department of Energy in 1986 and yielded an essentially 100 percent core recovery down to its total depth of $161 \mathrm{~m}$ (528 ft.).
Open-File Report 0-88-5 is now available at the Oregon Department of Geology and Mineral Industries, 910 State Office Building, 1400 SW, Fitth Avenue, Portland OR 97201-5528. The price is $\$ 8$. Orders under $\$ 50$ require prepayment.

\section{GRC 1989 ANNUAL MEETING HONORS 30 YEARS OF COMMERCIAL ACTIVITY AT THE GEYSERS}

With over 650 members of the geothermal community in attendance, the Geothermal Resources Council held its 13th Annual Meeting in Santa Rosa, California, October 1-4, 1989. The meeting program was entitled "The Geysers Three Decades of Achievement: A Window in the Future," and many of the technical sessions were devoted to the characteristics of The Geysers field and development activities there.

In addition, two of the earliest participants in the development of the field came out of retirement to address the assembly. Dr. Carol Otte, former president of Unocal's Geothermal Division, spoke at the opening session on "Three Decades of Achievement at The Geysers," and Joseph W. Aidlin, former general counsel of Magma Power Co., addressed a luncheon session on the future of geothermal energy. " I believe," he said, "that for generations to come, the contributions of those who conceived of the potential of The Geysers and confirmed that potential will stand as an example of what we in this land can accomplish if we set ourselves the task of creating useful, enduring values."

The meeting was followed by field trips to The Geysers and to direct use sites in Napa and Lake Counties. 


\section{UPCOMING MEETINGS, CONFERENCES, WORKSHOPS}

\section{DECEMBER 1989}

American Geophysical Union, fall meeting, San Francisco, California, December 4-8, Phone: (202) 4626903

\section{JANUARY 1990}

15th Workshop on Geothermal Reservoir Engineering, Stanford, Calfornia, January 23-25, Phone: (415) 723-4745

\section{FEBRUARY 1990}

Borehole Geophysics for Petroleum, Hydrogeology, Mining, and Engineering Applications, Phoenix, Arizona, February 1-3, Phone: (602) 621-3054

\section{MARCH 1990}

Energy Technology Conference and Exposition, Washington, D.C., March 19-21, Phone: (301) $252-$ 9250

APRIL 1990

DOE Geothermal Program Review VIII, San Francisco, California, April 17-20, Phone: (703) 998-3733

\section{MAY 1990}

American Geophysical Union, spring meeting, Baltimore, Maryland, May 29 June 1, Phone: (202) $462-$ 6900

52nd Annual Meeting of the European Association of Exploration Geophysicists, Copenhagen, Denmark, May 29 - June 1

JUNE 1990

Hydrologic Aspects of Global Climate Change, Lake Chelan, Washington, June 13-15, Phone: (202) 462-2009

81st Annual Conference of the International District Heatery and Cooling Association, Toronto, Canada, Phone: (202) 429-5111

\section{JULY 1990}

Circum-Pacific Energy and Mineral Resources Conference, Honolulu, Hawail, July 29 - August 3. Phone: (918) 584-2555

\section{AUGUST 1990}

25th Intersoclety Energy Conversion Engineering Conference, Reno, Nevada, August 12-17, Phone: (212) 705-7324

Remote Sensing and Water Resources, Enschede, Netherlands, August 20-24

Western Pacific Geophysics Meeting, Kanazara, Japan, August 21-25, Phone: (202) 462-6900 
1990 International Symposium on Geothermal Energy, Geothermal Resources Council, Kailua Kona, Hawaii, August 20-24

\section{SEPTEMBER 1990}

Deep-Seismic Reflection Profiling, Bayreuth, West Germany, September 4-7

Computers and Minerals Research, Berlin, West Germany, September 17-20

World Renewable Energy Congress, University of Reading, Reading, UK, September 23-28

Association of Engineering Geologists, annual meeting, Pittsburgh, Pennsylvania, September 30 October 6

Industrial Power Conference, American Society of Mechanical Engineers, St. Louis, Missouri, September 30 - October 4, Phone: (212) 705-7795

\section{MAY 1991}

American Geophysical Union, spring meeting, Baltimore, Maryland, May 28 -June 1, Phone: (202) 4626900

Society of Exploration Geophysicists, annual meeting, San Fransisco, California, Phone: (918) 4933516

\section{DECEMBER 1991}

American Geophysical Union, fall meeting, San Francisco, California, December 9-13, Phone: (202) $462-$ 6900

\section{MAY 1992}

Geological Association of Canada/Mineralogical Association of Canada, annual meeting, Wolfville, Nova Scotia, May 25-27, Phone: (902) 426-6759

Geological Society of America, annual meeting, Cincinnati, Ohio, October 26-29, Phone: (303) 4472020

\section{OCTOBER 1993}

Geological Society of America, annual meeting, Boston, Massachusetts, October 25-28, Phone: (303) 447-2020

\section{MAJOR SOURCES OF GEOTHERMAL INFORMATION}

This section of the GPM presents a representative sample of geothermal literature which has been reported since the last issue. Wider coverage of the literature may be found in a bimonthly publication of current abstracts entitled "Geothermal Energy" published by DOE's Office of Scientific and Technical Information. This publication may be obtained from the National Technical Information Service, Springfield, VA 22161 as PB 88-914700. The annual subscription price for six issues is $\$ 90.00$ (domestic) and $\$ 180.00$ (outside the North American continent). This publication typically lists each separate paper, article, or report 
derived from another publication, such as conference proceedings, as a separate entry. Space does not permit separate listings in the GPM; thus, the following are recommended:

Geothermal Resources Council Bulletin

Monthly Publication of GRC

P.O. Box 1350

Davis, California 95617-1350

Geothermal Resources Council Transactions,

Proceedings, GRC Annual Meetings.

Stanford University Annual Workshop on

Geothermal Reservoir Engineering

Stanford Geothermal Program

Dept. of Petroleum Engineering

Stanford, California 94305

Proceedings of the Annual Geothermal Program Review, Geothermal Technology Division, U.S. Department of Energy

Avallable from the National Technical Information Service

U.S. Department of Commerce

Springfield, Virginia 22161. (No. VI held April 19-21, 1988;

No. VII held March 21-23, 1989)

Electric Power Research Institute

Annual Geothermal Conference and Workshop

Technical Information Center,

Pal Alto, California 94303

\section{GEOTHERMAL ENERGY}

U.S. Department of Energy, Programs in Renewable Energy, Geothermal Energy Program Summary, Vol. I: Overview, Fiscal Year 1988, DOE/CH 10093-49 (Feb. 1989).

Ibid, Volume II: Research Summaries, DOE/CH 10093-50 (March 1989).

U.S. Department of Energy, Geothermal Technology Division, Five Year Research Plan, 1988-1992, DOE/CE0248 (Oct. 1988).

RESOURCE STATUS AND ASSESSMENT

Bechtel National Inc., Hot Dry Rock Venture Investigation: Final Report, NTIS, PC A/12/MF A01; GPO DE88006872/JAH (Jan. 1988).

Waag, C.J. and S.H. Wood, Analysis of Historical and Current Drawdown and Production Data from the Boise Geothermal System. Research technical completion report. Boise State University, Dept. of Geology and Geophysics, NTIS, PC A04/MF A01 (Aug. 1987). 
Reeder, J.W., et al., The Resource and Development Potential of the Makushin Volcano Geothermal Reservoir of the Aleutian Islands, Alaska, Alaska Division of Geological and Geophysical Surveys, In Situ; 11: No 1 (March 1987).

Dondanville, R.F., Geothermal Energy, Status in 1987, Unocal Geothermal Division, Bulletin, American Association of Petroleum Geologists; 71: No. 5 (May 1987).

Bechtel National Inc., Hot Dry Rock Venture Risks Investigation: Final Report, NTIS, PC A12/MF A01; GPO DE88006872/JAH (Jan. 1988).

\section{GEOLOGY AND HYDROLOGY OF GEOTHERMAL SYSTEMS}

Vuataz, F.D. and F. Goff, Water Geochemistry and Hydrology of the Shallow Aquifer at Roosevelt Hot Springs, Southern Utah: A Hot Dry Rock Prospect, NTIS, PC A/04/MF A01; GPO DE 88007160/JAH (Dec. 1987).

Pruess, $\mathrm{K}$ and Y.S. Wu, A Semi-Analytical Method for Heat Sweep Calculations in Fractured Reservoirs, Lawrence Berkeley Laboratories, NTIS, PC A02/MF A01; GPO 88008245/JAH (Jan. 1988).

Barton, C.A., et al., In-situ Stress Orientation and Magnitude at the Fenton Geothermal Site, New Mexico, Determined from Wellbore Breakouts, Stanford University, Department of Geophysics, Geophysical Research Testing; 15: No 5, 467-470 (May 1988).

Hulen, J.B., et al., Molybdenum Mineralization in an Active Geothermal System, Valles Caldera, New Mexico, University of Utah Research Institute, Geology: 15: No. 8, 748-752 (Aug. 1987).

Nye, C.J. Stratigraphy, Petrology, and Geochemistry of the Spurr Volcanic Complex, Eastern Aleutian Arc, Alaska, Alaska University, Geophysical Institute, NTIS, PC A07/MF A01; GPO DE88006849/JAH (Dec. 1987).

Prucha, R.H., Heat and Mass Transfer in the Klamath Falls, Oregon, Geothermal System, Lawrence Berkeley Laboratory, NTIS, PC A09/MF, GPO DE 87014676 (May 1987).

James, E.D., Fault-dominated Geothermal Reservoirs, Chevron Resources Co., Bulletin American Association of Petroleum Geologists: 71: No. 5 (May 1987).

Priest, G.R., Investigation of the Thermal Regime and Geologic History of the Cascade Volcanic Arc: First Phase of a Program for Scientific Drilling in the Cascade Range," Oregon State Dept. of Geology and Mineral Industries, NTIS, PC A07/MF 101; 1; GPO DE 87013077 (1987).

Taylor, E.M., Field Geology of the Northwest Quarter of the Broken Top 15' Quadrangle Deschutes County, Oregon, Ibid, NTIS, PC 103/MF A01; 1; GPO DE 87013079 (1987).

Goff, F.E., et al., Hydrogeochemical Investigation of Six Geothermal Sites in Honduras, Central America, Los Alamos National Laboratory, NTIS, PC A09/MF A01; 1; GPO 87014713 (June 1987).

Vuataz, F.D. and F. Goff, Water Chemistry and Hydrogeology of the Shallow Aquifer at Roosevelt Hot Springs, Southern Utah: A Hot Dry Rock Prospect, Los Alamos National Laboratory, NTIS, PC A04/MF A01; GPO DE88007160/JAH (Dec. 1987). 


\section{GEOTHERMAL EXPLORATION}

Peppin, W.A., Shallow-crusted Magma Zones in and South of Long Valley, California: Final report for the period Sept. 1986 to 30 April 1988, Mackay School of Mines, Seismological Laboratory, NTIS, PC A02/MF A01, GPO DE 8800 9214/JAH (April 1988).

Street, L.V., and R.E. DeTar, Geothermal Resource Analysis in Twin Falls County, Idaho: Idaho Dept. of Water Resources Water Information Bulletin, Bureau of Land Management, NTIS, PC A06/MF A01; GPO DE 88006910/JAH (July 1987).

Shevenell, L., et al., Lithologic Descriptions and Temperature Profiles of Five Wells in the Southwestern Valles Caldera Region, New Mexico, Los Alamos National Laboratory, NTIS, PC A03/MF A01, GPO DE 88007158/JAH (Jan. 1988).

Starguist, V.L., Core Log; Valles Caldera No. 2A, New Mexico, Los Alamos National Laboratory, NTIS, PC A05/MF A01; GPO DE 88007146/JAH (Jan. 1988).

Goldstein, N.E., Potential Field and Electromagnetic Studies: Introduction, Lawrence Berkeley Laboratory, NTIS, PC A02/MF A01; GPO DE 88006324/JAH (Jan. 1988).

Lovenitti, J.L. and W.L. D'Olier, Clackamas 4800-foot Thermal Gradient Hole: Cascade Geothermal Drilling: Final Technical Report, Thermal Power Co., NTIS, PC A05/MF A01; GPO DE88002704 (Sept. 30, 1987).

Tsang, Chin-Fu, A Borehole Fluid Conductivity Logging Method for the Determination of Fracture Inflow Parameters, Lawrence Berkeley Laboratory, NTIS, PC A04/MF A01; GPO 88004883/JAH (Oct. 1987).

Wollenberg, $\mathrm{H}$. et al., A Core Hole into the Hydrothermal System of the Long Valley Caldera, Lawrence Berkeley Laboratory and U.S. Geological Survey, NTIS PC A02/MF A01; GPO DE88006335/JAH (March 1987).

Carle, S.F. and N.E. Goldstein, A Three-Dimensional Gravity Model of the Geologic Structure of Long Valley Caldera, Lawrence Berkeley Laboratory, NTIS, PC A03/MF A01; GPO DE88006331/JAH (March 1987).

Daley, T.M., Analysis of P-and S-wave VSP (Nertical Seismic Profile) Data from the Salton Sea Geothermal Field, Lawrence Berkeley Laboratory, NTIS, PC A12/MF A01; GPO DE88006348/JAH (Sept. 1987).

Skaugen, E., The Effects of Quasi-Random Drill Bit Vibrations Upon Drillstring Dynamic Behavior, Rogaland Research Institute, from Proceedings of the Annual Technical Conference and Exhibition of the Society of Petroleum Engineers, Dallas, Texas, SPE Technical Paper 16660 (Sept. 1987).

Selim, M.S., E.D. Sloan, Hydrate Dissociation in Sediment, Colorado School of Mines, Ibid., SPE Technical Paper 16859 (Sept. 1987).

Sneddon, M.V., Recent Advances in Polycrystalline Diamond (PCD) Technology Open New Frontiers in Drilling, Ibid., SPE Technical Paper 17007 (Sept. 1987).

Trujillo, P.E., et al., Chemical Analysis and Sampling Techniques for Geothermal Fluids and Gases at the Fenton Hill Laboratory, Los Alamos National Laboratory, NTIS, PC A05/MF A10; GPO DE87014707 (June 1987). 
Goff, F., et al. eds., Downhole Fluid Sampling at the SSSDP (Salton Sea Scientific Drilling Project) California 2-14 Well, Salton Sea, California, Los Alamos National Laboratory, NTIS PC A03/MF A01; 1; GPO DE87014701 (July 1987).

Aki, K., The Seismology of Continental Thermal Regimes: Final Report for Period April 1, 1986-April 1, 1987, University of Southern California Dept. of Geological Sciences, NTIS, PC A04/MF A01; 1; GPO87014100 (July 1987).

Kruger, P. and L. Semprini, Radon As An In Situ Tracer in Geothermal Reservoirs: Final Report, Stanford University Department of Civil Engineering, Electric Power Research Institute, Research Reports Center, Box 50490, Palo Alto, CA, File No. T187920551 (Aug. 1987).

Dennis, B.R., et al., Results of Investigation at the Miravalles Geothermal Field, Costa Rica: Part 1, Well Logging, Los Alamos National Laboratory, NTIS, PC A03/MFA01-OSTI; GPO DE89007456/JAH (March 1989).

\section{LEGAL, INSTITUTIONAL, AND ECONOMIC ASPECTS}

Satrape, J.V., Potential Impacts of Artificial Intelligence Expert Systems on Geothermal Well Drilling Costs: Final Report, Meridian Corp., NTIS PC A07/MF A01; GPO DE88003239/JAH (1987).

Meridian Corp., Economic Decision Making Model for Geothermal Sludge Disposal Alternatives (EDMGSD): Version 1.0, NTIS PC A04/MF A01; GPO DE88000277/JAH (Order software packages from National Energy Software Center, Argonne National Laboratory, 9800 S. Cass Avenue, Argonne, IL 60439 (Sept. 1987).

New Energy and Industrial Technology Development Organization, Research on the Vision for Introducing the Utilization of the Geothermal Resources, Tokyo, Japan, U.S. Sales NTIS, PC A11/MF A01; GPO DE88756490/JAH (May 1988).

ENVIRONMENTAL ASPECTS AND WASTE DISPOSAL

ENVIRONMENTAL ASPECTS AND WASTE DISPOSAL

$\$ \% \% \% \%$

Wong, M.M. and A.L. Shugarman, Process for Reducing the Concentration of Heavy Metals in Geothermal Brine Sludge, U.S. Patent 4,710,367 to Union Oil Co. of California, Mono Power Co., and Southern Pacific Land Co. (Dec. 1987).

\section{BY-PRODUCTS}

Awerbuch, L., et al., Apparatus and Method for Mineral Recovery from Geothermal and Geopressured Brines, USA Patent 4,718,236 to Bechtel Power Corp. (Jan. 1988). 


\section{GEOTHERMAL POWER PLANTS}

Ellis, P.F., Downwell Pump Reliability: Geothermal Experience Update: Final Report, Radian Corp., Electric Power Research Institute, Research Reports Center, Box 50490, Palo Alto, CA 94303, Order No. TI88920184/JAH (Jan. 1988).

ESCOR, Simulator-Analyzer for Binary Cycle Geothermal Power Plants, Ibid., File No. TI87920522 (July 1987).

\section{GEOTHERMAL ENGINEERING}

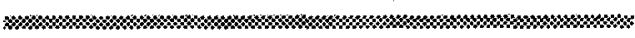

Hirasuna, A.R., et al., Elastomer Liners for Geothermal Tubulars Y267 EPDM Liner Program, L'Garde Inc., NTIS, PC A04/MF A01; GPO DE88007014/JAH (Dec. 1987).

Bennett, G.A., Active Cooling for Downhole Instrumentation: Preliminary Analysis and System Selection, Los Alamos National Laboratory, NTIS, PC A07/MF A01; GPO DE88007080/JAH (March 1988).

Giver, R.C. and R.R. Mikatarian, Numerical Simulation of Fluids-particle Flows: Geothermal Drilling Applications, Sandia National Laboratories, Journal of Fluids Engineering; 109; No. 3 (Sept. 1987).

Morris, C.W., Analysis of Geothermal Wells in Naturally Fractured Formations with Rate-Sensitive Flow, Schlumberger Offshore Services, SPE Formation Evaluation; 2; No. 4 (Dec. 1987).

Anderson, D.N., Twelve Month Follow-up Report of the Conference to Promote International Sales of U.S. Geothermal Equipment (CORECT Project): Final Report, Geothermal Resources Council, NTIS, PC A03/MF A01; GPO DE89006821/JAH (Dec. 1988).

\section{BASIC GEOTHERMAL DATA AND THEORY}

New York State University, Energy Related Studies Utilizing Thermochronology: Progress Report, May 1, 1987-April 30, 1988, NTIS, PC A02/MF A01; GPO DE88007292/JAH (1988).

Maeder, P.F. and J. Kestin, Two-Phase Flow in Geothermal Systems: Final Report, July 15, 1986-April 30, 1987, NTIS, Brown University, PC A02/MF A01; GPO DE87014024 (Aug. 1987).

Laoulacke, R.N., et al., Theoretical and Empirical Study of a Single-substance, Upward Two-Phase Flow in a Constant-Diameter Adrobiatic Pipe, Ibid., NTIS, A10/MF A01;1; GPO 87014028 (May 1987). 


\section{U.S. DEPARTMENT OF ENERGY GEOTHERMAL R\&D PROGRAM PARTICIPANTS}

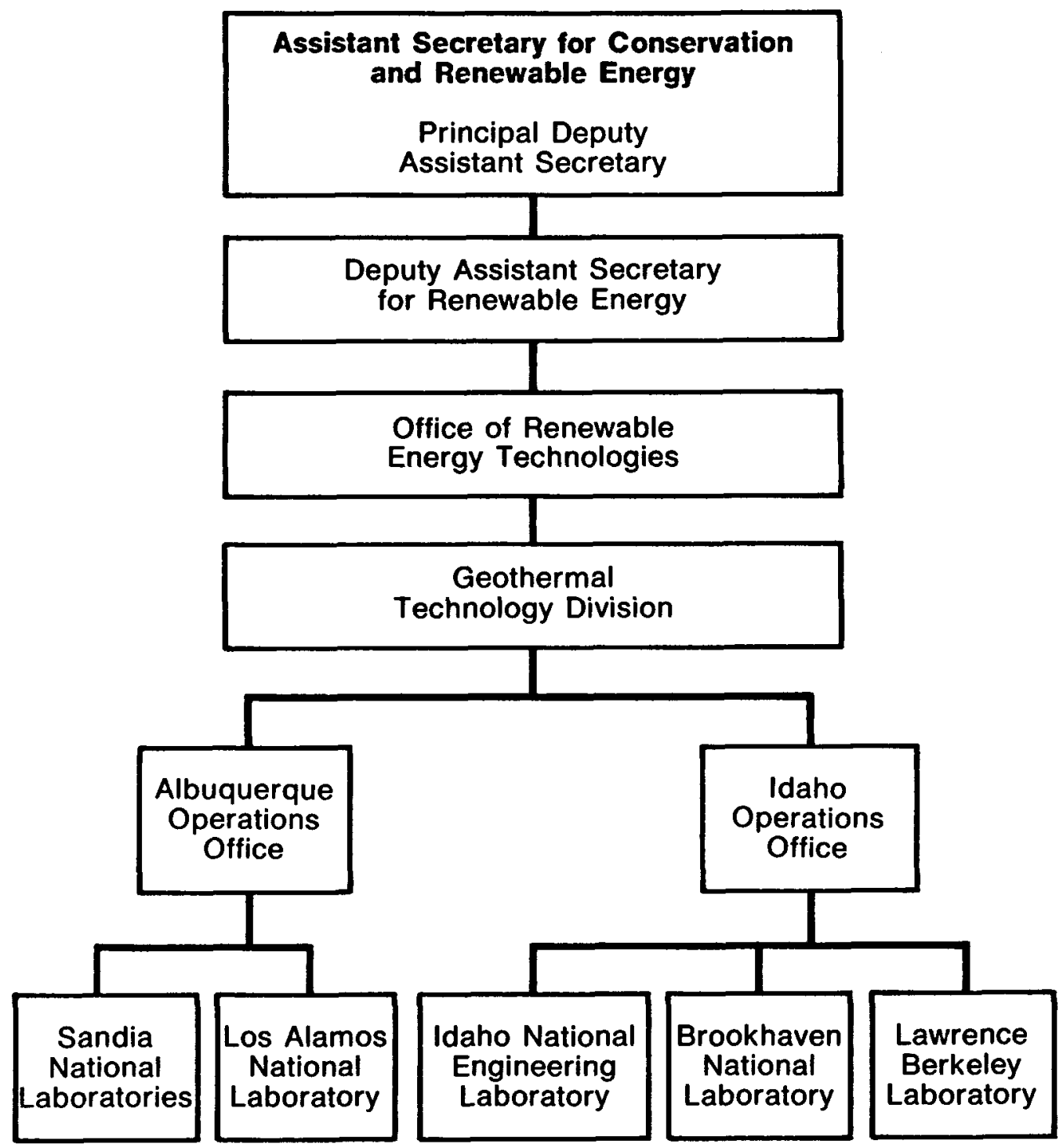


U.S. Department of Energy CE 342 Room $5 \mathrm{H} 065$ 1000 Independence Ave., S.W. Washington, D.C. 20585

Phone (202) 586 - (ext.)

FTS 896 - (ext.)

Robert San Martin

Ronald Loose

John E. Mock

Allan J. Jelacic

David B. Lombard

Ralph E. Burr

Raymond Fortuna

Gladys Hooper

Raymond J. LaSala

Lew W. Pratsch

James E. Rannels

Marshall Reed
9275

8084

5340

6054

4952

5335

1711

1146

4198

1512

8070

8076
Deputy Assistant Secretary for Conservationand Renewable Energy

Director, Office of Renewable Technologies

Director, Geothermal Technology Division

Team Leader, Geothermal Geosciences Research

Team Leader, Geothermal Conversion Research

Manager, Geothermal Loan Guaranty Program, Technology Transfer, CORECT Activities

Manager, Geopressured Resources

Manager, AdvancedBrine Chemistry, Magma Energy Extraction

Manager, Heat Cycle Research, Materials

Manager, Hard Rock Penetration, Low Enthalpy Systems

Manager, Hot Dry Rock

Manager, Hydrothermal Reservoir Technology 


\section{DOE FIELD OFFICES (WITH GEOTHERMAL PROGRAMS)}

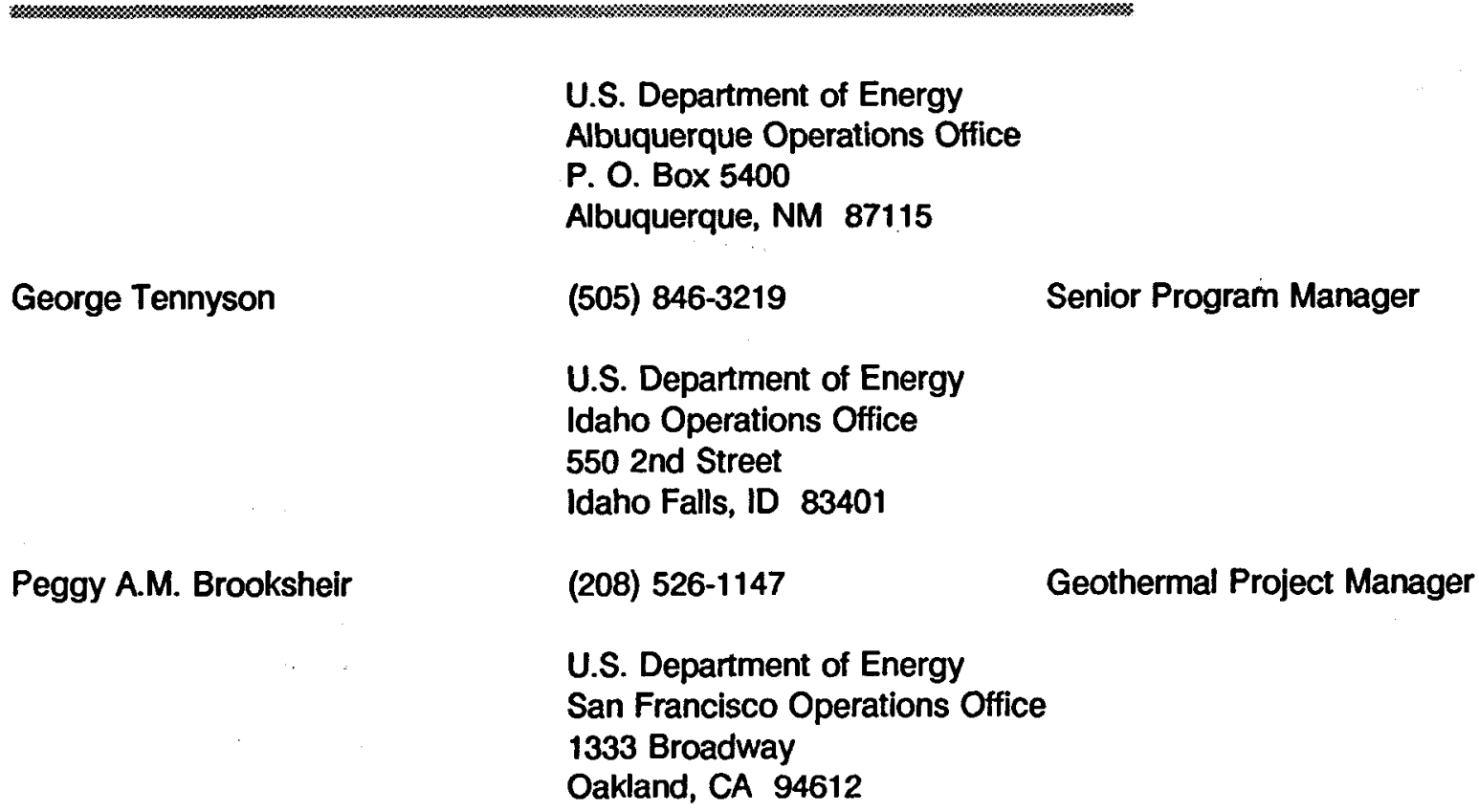

U.S. Department of Energy

Albuquerque Operations Office

P. O. Box 5400

Albuquerque, NM 87115

George Tennyson

(505) $846-3219$

Senior Program Manager

U.S. Department of Energy

Idaho Operations Office

550 2nd Street

Idaho Falls, ID 83401

Peggy A.M. Brooksheir

(208) $526-1147$

Geothermal Project Manager

U.S. Department of Energy

San Francisco Operations Office

1333 Broadway

Oakland, CA 94612

Martin W. Molloy

(415) $273-7945$

Senior Program Manager

\section{NATIONAL LABORATORIES (GEOTHERMAL RESEARCH)}

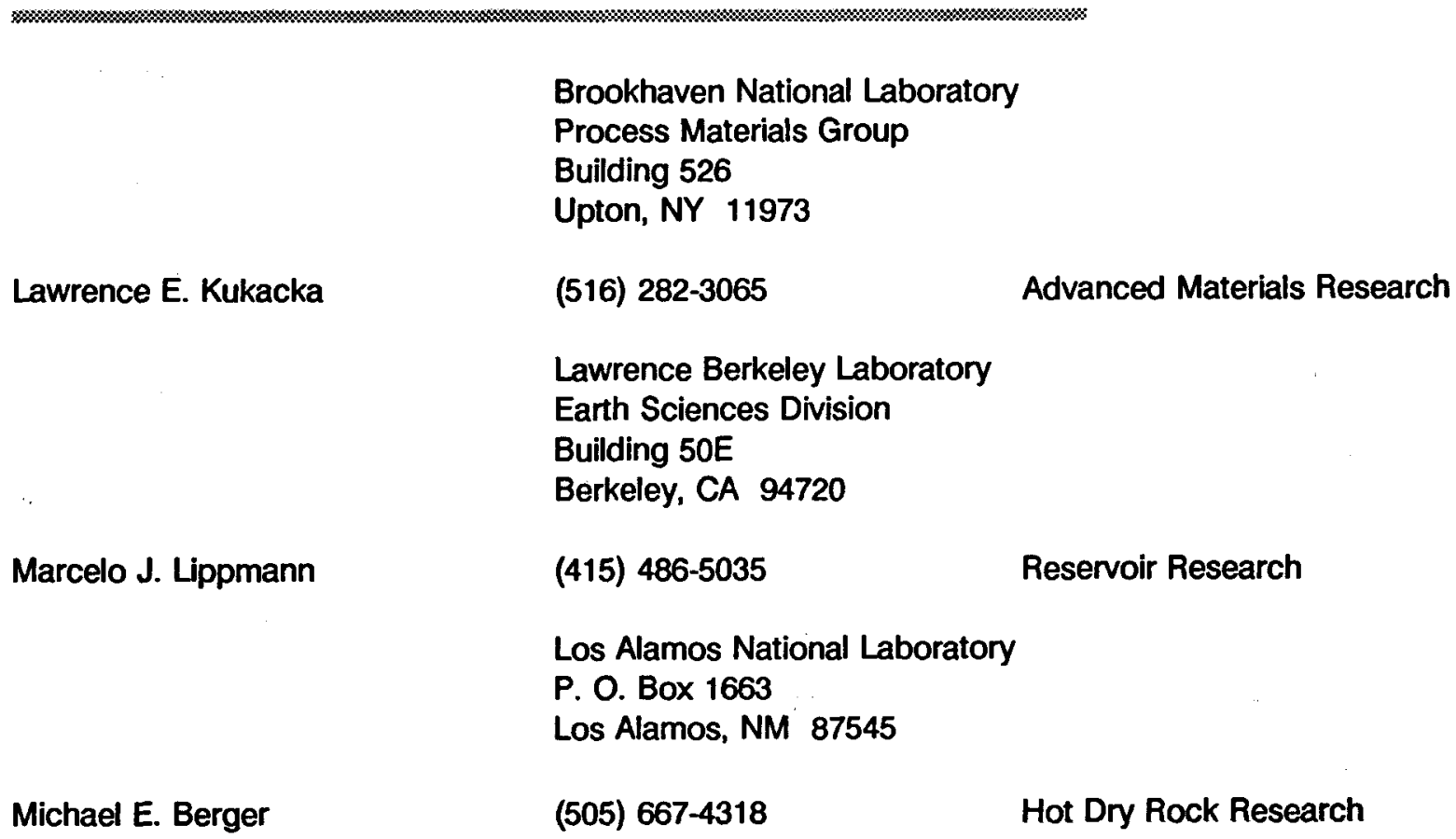


Sandia National Laboratories

P. O. Box 5800, Division 6252

Albuquerque, NM 87185

James C. Dunn

(505) 844-4715

Idaho National Engineering

Laboratory

P. O. Box 1625

Idaho Falls, ID 83415

Jane Negus-deWys

Greg Meines
(208) 526-1744

(208) 528-0260
Geothermal Drilling Organization; Hard Rock Penetration; Magma Resources

\section{Geopressured Resources}

Energy Conversion 